CAROLINA FEHER DA SILVA

\title{
ABORDAGEM COMPUTACIONAL E PSICOFÍSICA DA ALOCAÇÃO ATENCIONAL E TOMADA DE DECISÃO
}

Tese apresentada ao Programa de PósGraduação em Fisiologia Humana do Instituto de Ciências Biomédicas da Universidade de São Paulo, para obtenção do Título de Doutor em Ciências. 


\section{CAROLINA FEHER DA SILVA}

\section{ABORDAGEM COMPUTACIONAL E PSICOFÍSICA DA ALOCAÇÃO ATENCIONAL E TOMADA DE DECISÃO}

Tese apresentada ao Programa de PósGraduação em Fisiologia Humana do Instituto de Ciências Biomédicas da Universidade de São Paulo, para obtenção do Título de Doutor em Ciências.

Área de concentração: Neurofisiologia.

Orientador: Prof. Dr. Marcus Vinícius Chrysóstomo Baldo 
DADOS DE CATALOGAÇÃO NA PUBLICAÇÃO (CIP)

Serviço de Biblioteca e Informação Biomédica do

Instituto de Ciências Biomédicas da Universidade de São Paulo

(C) reprodução total

Feher-da-Silva, Carolina.

Abordagem computacional e psicofísica da alocação atencional e tomada de decisão / Carolina Feher da Silva. -- São Paulo, 2011.

Orientador: Marcus Vinícius Chrysóstomo Baldo.

Tese (Doutorado) - Universidade de São Paulo. Instituto de Ciências Biomédicas. Departamento de Fisiologia e Biofísica. Área de concentração: Fisiologia Humana. Linha de pesquisa: Neurofisiologia.

Versão do título para o inglês: Computational and psychophysical approach to attentional allocation and decision making.

Descritores: 1. Redes neurais 2. Algoritmos genéticos 3 . Atenção 4. Tomada de decisão 5. Cadeias de Markov 6. Problemas relacionados à evolução I. Baldo, Marcus Vinícius Chrysóstomo II. Universidade de São Paulo. Instituto de Ciências Biomédicas.

Programa de Pós-Graduação em Fisiologia Humana III. Título. 
Candidato(a)

Carolina Feher da Silva.

Título da Tese:

Abordagem computacional e psicofísica da alocação atencional e tomada de decisão .

Orientador(a): $\quad$ Marcus Vinícius Chrysóstomo Baldo.

A Comissão Julgadora dos trabalhos de Defesa da Tese de Doutorado, em sessão pública realizada a ................................., considerou

\section{( ) Aprovado(a) ( ) Reprovado(a)}

\begin{tabular}{|c|c|}
\hline Examinador(a) & $\begin{array}{l}\text { Assinatura: } \\
\text { Nome: ....... } \\
\text { Instituição: }\end{array}$ \\
\hline Examinador(a) & $\begin{array}{l}\text { Assinatura: } \\
\text { Nome: ....... } \\
\text { Instituição: }\end{array}$ \\
\hline Examinador(a) & $\begin{array}{l}\text { Assinatura: } \\
\text { Nome: ........ } \\
\text { Instituição: }\end{array}$ \\
\hline Examinador(a) & $\begin{array}{l}\text { Assinatura: } \\
\text { Nome: ....... } \\
\text { Instituição: }\end{array}$ \\
\hline Presidente: & $\begin{array}{l}\text { Assinatura: } \\
\text { Nome: ....... } \\
\text { Instituição: }\end{array}$ \\
\hline
\end{tabular}




\section{AGRADECIMENTOS}

Gostaria de agradecer acima de tudo ao professor Marcus Vinícius C. Baldo, que me orientou desde o mestrado e tornou a realização deste trabalho possível e um grande prazer. Agradeço também aos meus colegas do laboratório: André Cravo, Camila Victorino, Fernando Mayoral, Hamilton Haddad, Janaína Brizante, Milene Regatão e Peter Claessens. Sem a presença deles no meu dia a dia, este trabalho e o tempo gasto para fazê-lo teriam sido bem diferentes do que foram e, sem dúvida, muito piores. Vários professores me ajudaram de uma maneira ou de outra, mas gostaria de agradecer especialmente aos professores Nestor Caticha, Luiz Eduardo Ribeiro do Valle e Ronald Ranvaud.

Gostaria de agradecer à minha mãe pelo apoio dado aos meus estudos durante toda a minha vida, à minha tia Darcy, meu irmão Rodrigo, meu gato Plínio e todos os meus amigos. 


\section{RESUMO}

FEHER-DA-SILVA, C. Abordagem computacional e psicofísica da alocação atencional e tomada de decisão. 2011. 123 f. Tese (Doutorado em Fisiologia Humana) - Instituto de Ciências Biomédicas, Universidade de São Paulo, São Paulo, 2011.

O processo evolutivo deixa vieses no sistema nervoso de forma a optimizar as nossas capacidades cognitivas para a sobrevivência e reprodução no ambiente em que evoluímos. O objetivo deste trabalho é criar modelos computacionais de vida artificial nos quais três fenômenos cognitivos - a atenção seletiva, a tomada de decisão em sequências binárias e o tempo de reação ao aparecimento abrupto de um alvo precedido por pista - emerjam como consequência da adaptação evolutiva a um determinado ambiente. Nossos experimentos indicam que a atenção seletiva enviesa o processamento de estímulos sensoriais de forma a dar prioridade aos estímulos mais relevantes. Nas simulações realizadas, ela surgiu em populações de animais artificiais quando os estímulos tinham relevâncias diferentes, sendo que a seleção foi mais intensa quando a quantidade de recursos computacionais disponíveis para o processamento dos estímulos era reduzido. Nos experimentos de tomada de decisão em sequências binárias, nossas simulações apóiam a teoria de que a estratégia conhecida como pareamento de probabilidades, que os seres humanos em geral adotam neste tipo de experimento, é consequência de um viés cognitivo para a busca de padrões, que decorre da importância que a busca de regularidades no ambiente teve durante a evolução humana. No estudo do tempo de reação ao aparecimento abrupto de um alvo precedido por pista (válida, inválida ou neutra), o comportamento observado em seres humanos só pôde ser modelado em populações de animais artificiais quando, durante a vida dos animais, existia ruído e eles tinham que selecionar uma ação apropriada entre duas ações possíveis. Assim propomos que os resultados obtidos com seres humanos decorre de uma adaptação ao ambiente ruidoso em que uma ação apropriada a cada situação deve ser selecionada entre várias ações possíveis.

Palavras-chave: Vida artificial. Redes neurais. Algoritmos genéticos. Atenção seletiva. Pareamento de probabilidades. Tempo de reação. 


\begin{abstract}
FEHER-DA-SILVA, C. Computational and psychophysical approach to attentional allocation and decision making. 2011. 123 p. Ph. D. Thesis (Human Physiology) Instituto de Ciências Biomédicas, Universidade de São Paulo, São Paulo, 2011.
\end{abstract}

The evolutionary process leaves biases in the nervous system so that our cognitive capacities are optimized to survival and reproduction in the environment where we evolved. Our objective is to create computational Artificial Life models wherein three cognitive phenomena - selective attention, decision making in binary sequences and reaction time to the abrupt appearance of a target preceded by a cue - emerge as a consequence of evolutionary adaptation to a certain environment. Our experiments indicate that selective attention bias the processing of sensory stimulus so as to give high priority to the most relevant stimuli. In the performed simulations, it emerged in populations of artificial animals when the stimuli had different relevances, selection being more intense when the amount of computational resources available for stimulus processing was reduced. In our experiments of decision making in binary sequences, our simulations support the theory that the strategy known as probability matching, which human beings in general adopt in this kind of experiment, is a consequence of a cognitive bias to search for patterns, which results from the importance that the search for regularities in the environment had during human evolution. In the study of reaction time to the abrupt appearance of a target preceded by a (valid, invalid or neutral) cue, the behavior observed in human beings could only be modeled in populations of artificial animals when, during the animals' lives, there was noise and they had to select an appropriate action between two possible actions. Thus we propose that the results obtained with human beings result from an adaptation to noisy environment wherein an appropriate action to each simulation should be selected amongst several possible actions.

Keywords: Artificial Life. Neural networks. Genetic algorithms. Selective attention. Probability matching. Reaction time. 


\section{SUMÁRIO}

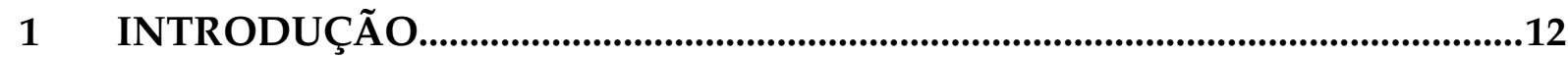

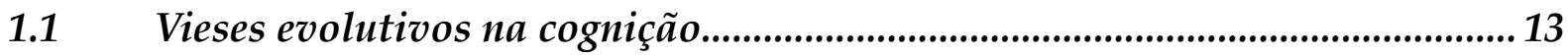

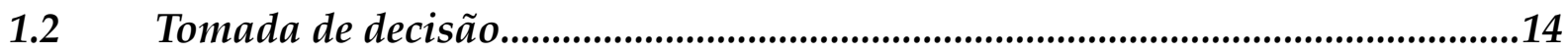

1.2.1 Cadeias de Markov e medidas de informação..................................................18

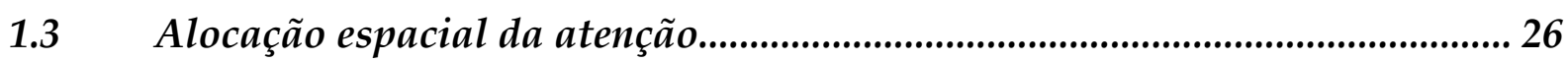

1.3.1 Mensuração da atenção: detectabilidade e tempos de reação......................27

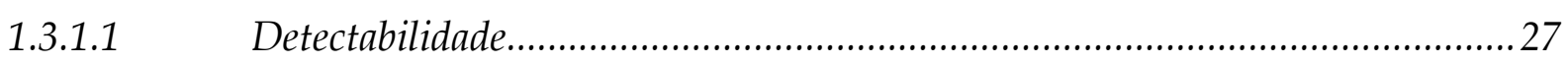

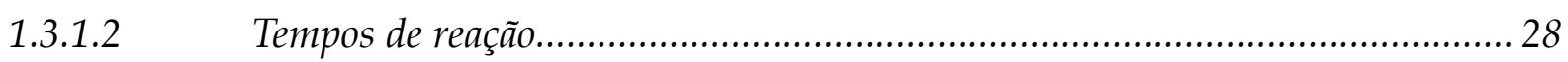

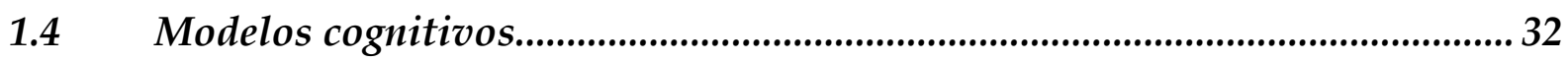

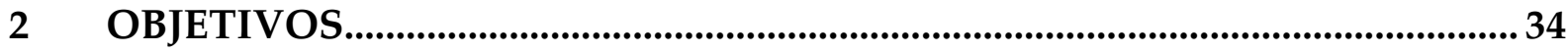

$2.1 \quad$ Objetivos gerais.............................................................................................

$2.2 \quad$ Objetivos especificos........................................................................................34

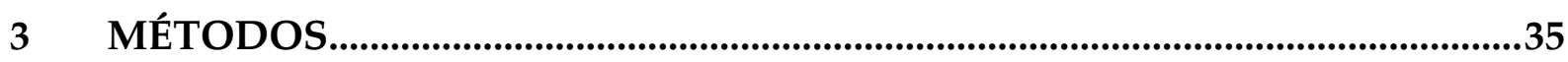

$3.1 \quad$ Redes Neurais................................................................................................

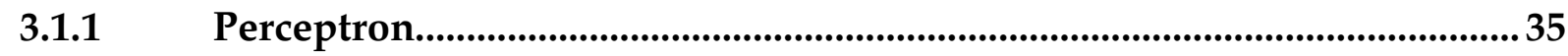

3.1.2 Modelo integra-e-dispara.............................................................................. 37

3.1.3 Aprendizado hebbiano.................................................................................. 37

3.1.4 Arquiteturas de redes neurais...........................................................................39

3.2 Algoritmos genéticos............................................................................... 39

3.2.1 Evolução de redes neurais artificiais................................................................ 42

3.3 Experimentos psicofísicos com seres humanos.....................................................43

3.4 Representação gráfica.........................................................................................4 43

4 TOMADA DE DECISÃO EM ESCOLHAS BINÁRIAS REPETIDAS................44

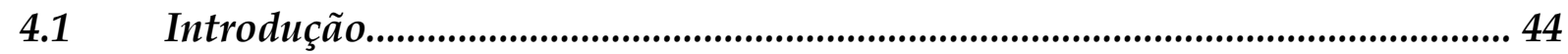

$4.2 \quad$ Experimento 1......................................................................................4

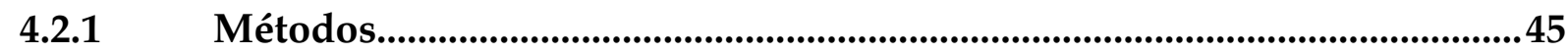

4.2.2 Resultados e Discussão Parcial.........................................................................47

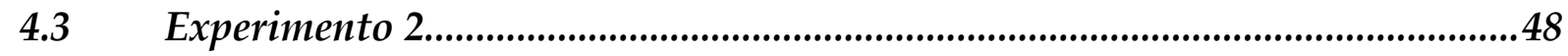

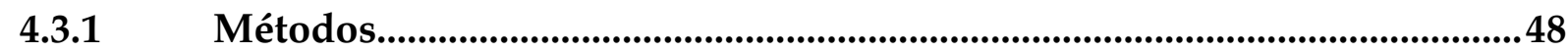

4.3.2 Resultados e Discussão Parcial...................................................................50

4.4 Experimentos 3 e 4 ............................................................................................ 56

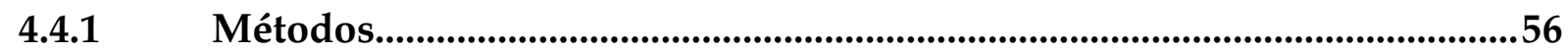

4.4.2 Resultados e Discussão Parcial.....................................................................58 


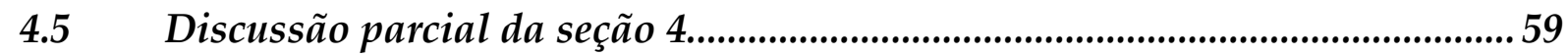

5 ALOCAÇÃO DA ATENÇÃO ESPACIAL............................................................60

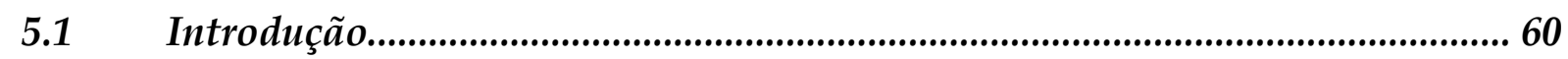

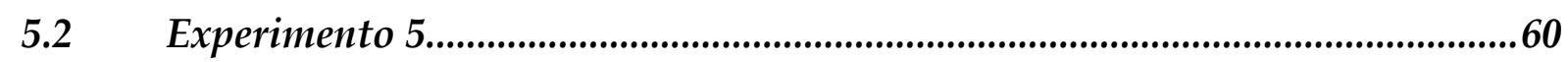

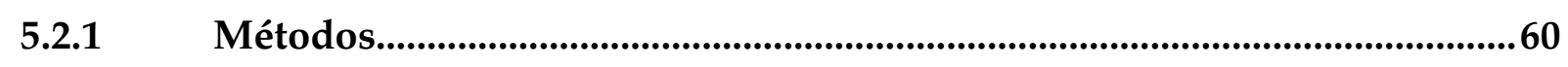

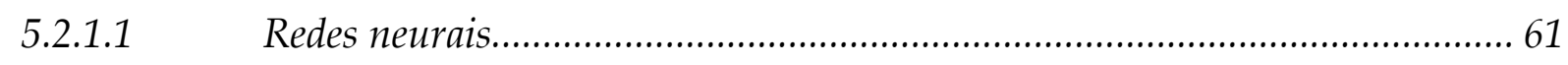

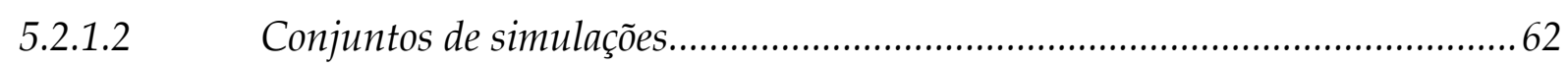

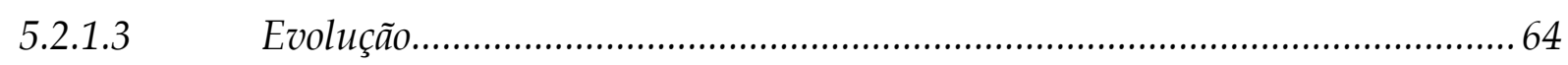

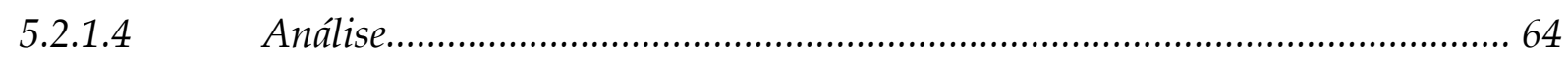

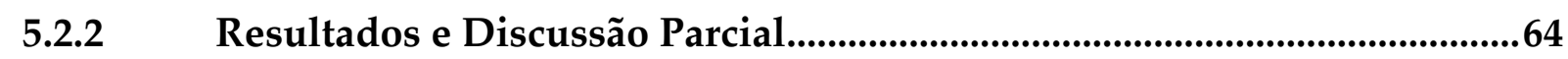

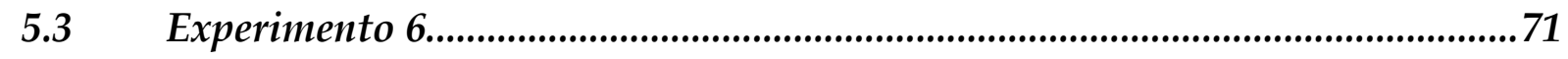

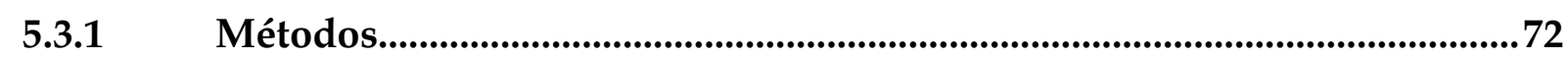

5.3.2 Resultados e Discussão Parcial.................................................................73

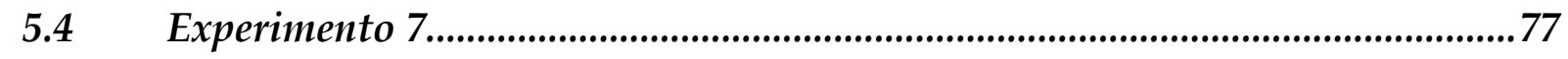

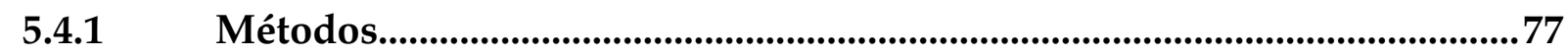

5.4.1.1 Situação de mesma relevância........................................................................ 79

5.4.1.2 Situação de relevâncias diferentes................................................................. 79

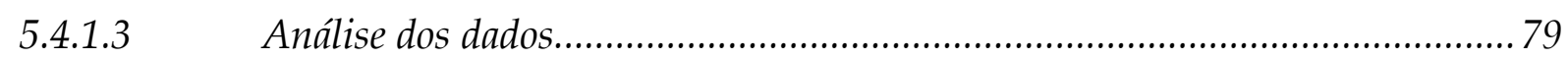

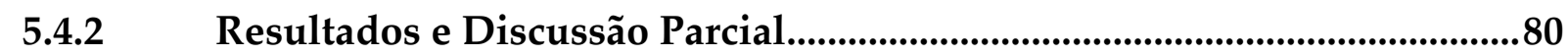

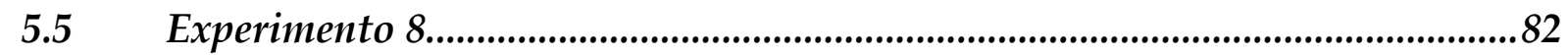

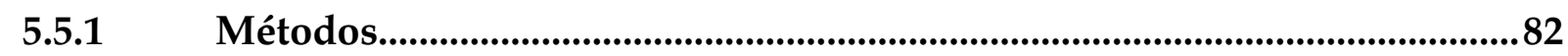

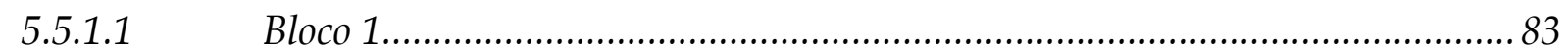

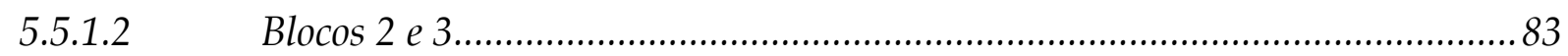

5.5.2 Resultados e Discussão Parcial................................................................84

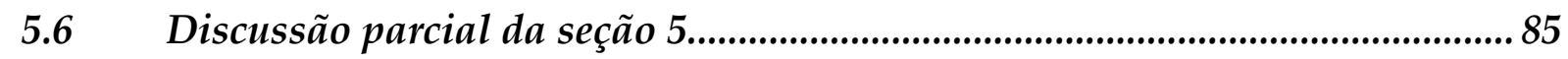

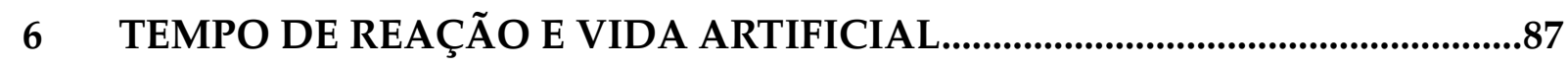

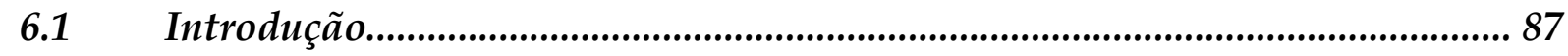

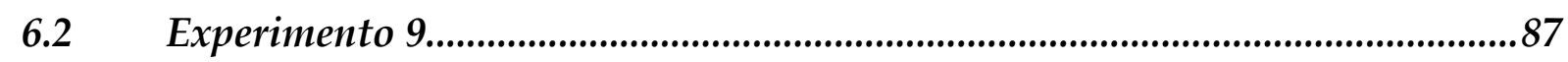

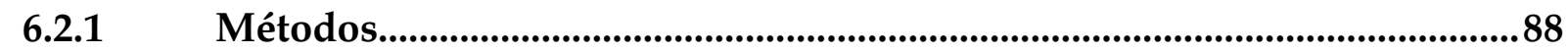

6.2.2 Resultados e Discussão Parcial.............................................................90

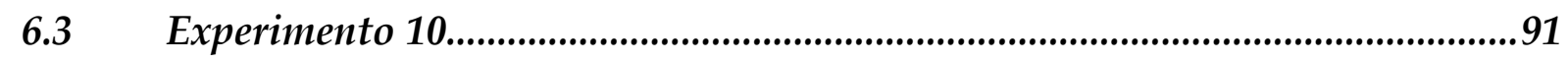

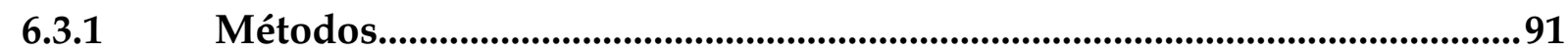

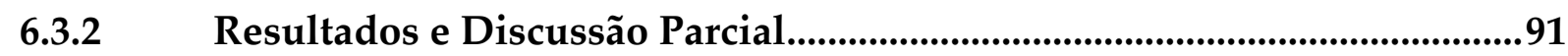

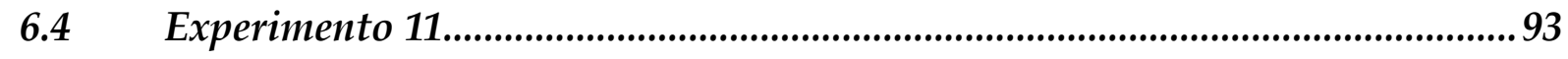

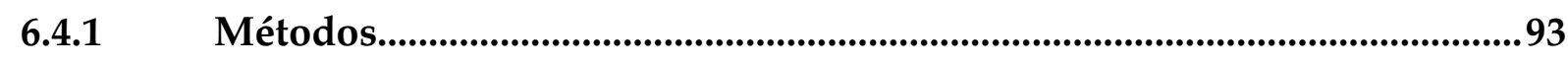


6.4.2 Resultados e Discussão Parcial..............................................................94

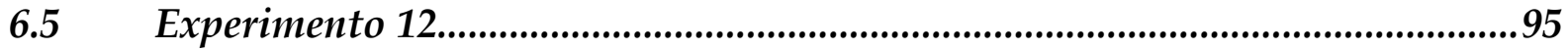

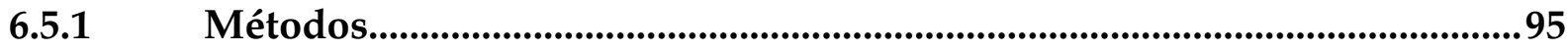

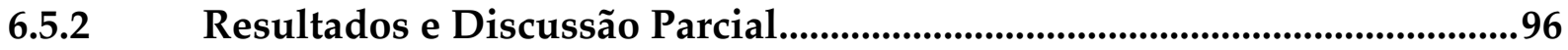

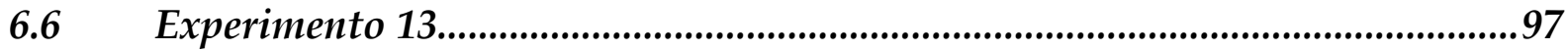

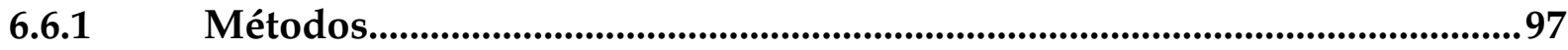

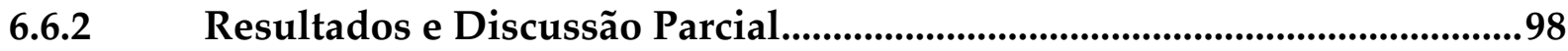

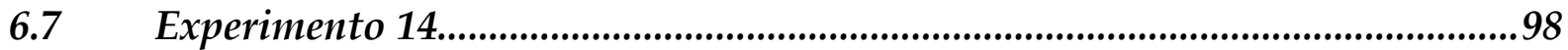

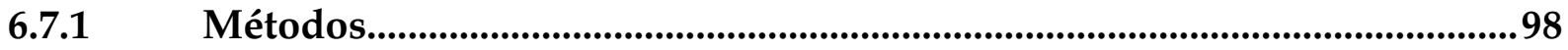

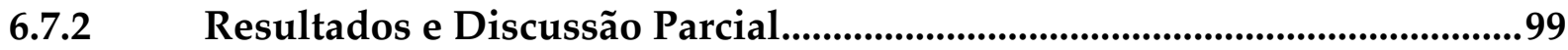

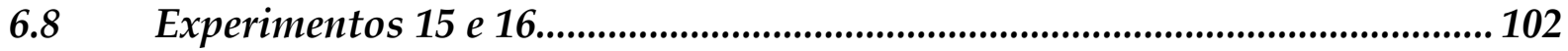

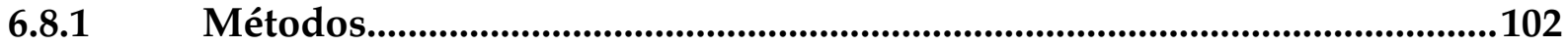

6.8.2 Resultados e Discussão Parcial................................................................103

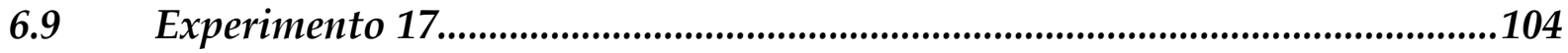

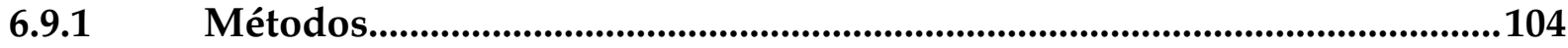

6.9.2 Resultados e Discussão Parcial....................................................................105

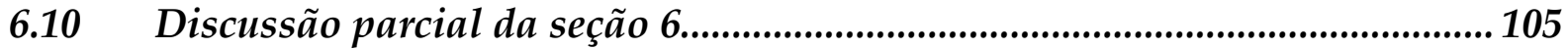

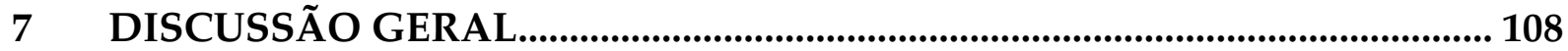

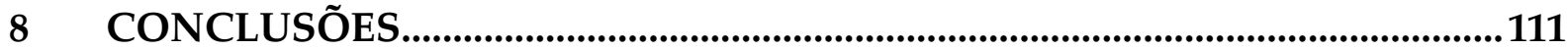

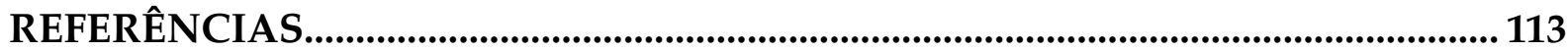




\section{INTRODUÇÃO}

Os seres vivos atuais são produtos de bilhões de anos de evolução. A fim de explicar como esta evolução ocorreu, no século XIX Charles Darwin propôs a teoria da evolução pela seleção natural, que ainda hoje é a base para o nosso entendimento deste processo. A teoria afirma que ocorrem variações hereditárias entre os organismos e que o ambiente exerce uma pressão seletiva de tal forma que alguns organismos com variações mais favoráveis tenham maior probabilidade de sobreviver e se reproduzir do que outros. O processo de seleção natural, agindo ao longo de gerações, torna uma população mais adaptada ao ambiente em que vive.

Quando o ambiente se modifica, uma característica que antes era uma vantagem pode se tornar uma desvantagem. Um exemplo clássico é o das mariposas inglesas da espécie Biston betularia (GRANT, 1999). Existe uma variabilidade na cor das mariposas: elas podem ser brancas ou pretas (Figura 1). Antes da Revolução Industrial, as árvores no ambiente em que as mariposas viviam eram cobertas por líquens, que davam aos troncos uma coloração clara. Por causa disso, as mariposas brancas pousadas nos troncos das árvores eram mais difíceis de serem localizadas por predadores do que as mariposas pretas, o que dava às primeiras uma vantagem evolutiva sobre as segundas. Com o advento da Revolução Industrial, a fuligem produzida nas fábricas devido à queima de carvão se depositou nos troncos das árvores, escurecendo-os. Desta forma, as mariposas pretas se tornaram mais difíceis de serem localizadas por predadores em relação às mariposas brancas e a vantagem evolutiva se inverteu.
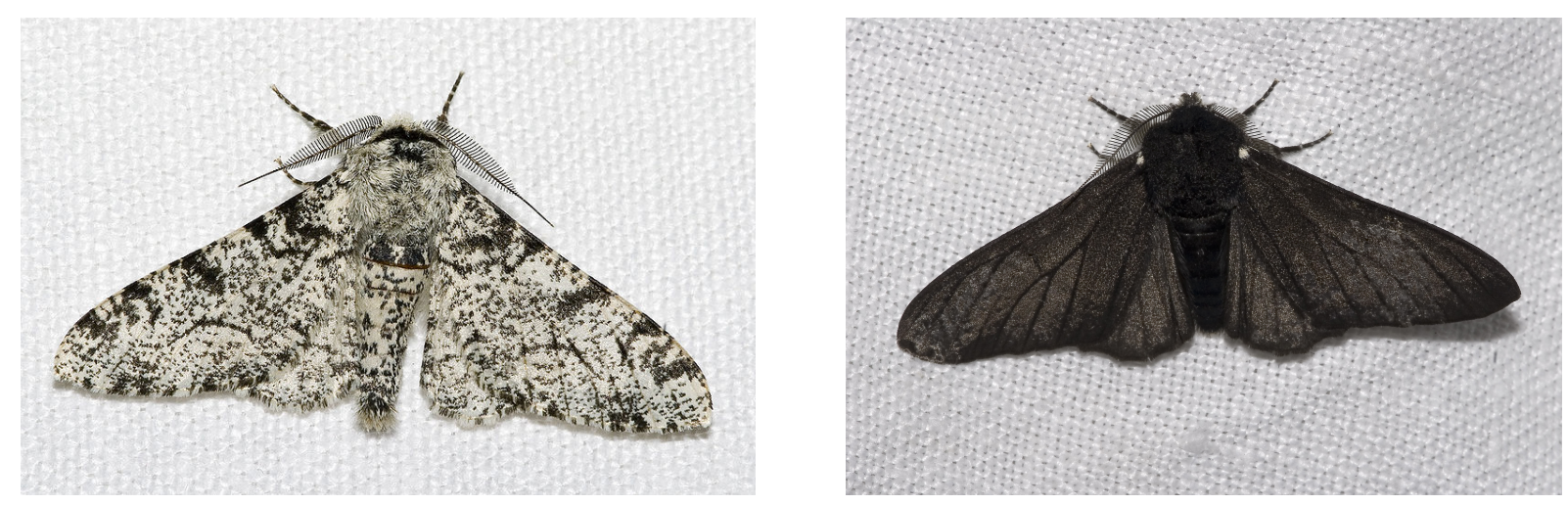

Figura 1 - Mariposas brancas e pretas da espécie Biston betularia. 


\subsection{Vieses evolutivos na cognição}

Assim como a cor das mariposas, a nossa cognição também está sujeita à pressão seletiva. Suas características atuais foram selecionadas por proporcionarem aos nossos ancestrais uma vantagem de sobrevivência e reprodução no ambiente em que eles viviam. Os diversos módulos cognitivos que surgiram no passado foram preservados na medida em que eles eram capazes de influenciar a geração de ações físicas e assim modificar a interação do indivíduo com o seu ambiente de forma vantajosa.

E assim como o ambiente das mariposas se modificou devido à Revolução Industrial, o nosso ambiente também se modificou recentemente. Por exemplo, desde o surgimento do gênero Homo há 2,5 milhões de anos até a Revolução Neolítica há 10 mil anos, os humanos viviam como caçadores-coletores em grupos familiares (CELACONDE; AYALA, 2007). Não existia a escrita, nem sociedades complexas, agricultura, computadores ou laboratórios de pesquisa. Assim, esperamos que os nossos processos cognitivos reflitam os desafios da vida na savana africana muito mais do que os das cidades modernas.

E ainda que os seres humanos tenham sido bem-sucedidos neste novo ambiente (até o presente pelo menos), nossa cognição está sujeita à necessidade de sobreviver no dia a dia, até que possamos gerar descendentes; deste modo ela pode não atuar de forma ótima no ambiente artificial de um experimento científico, em que o desempenho do voluntário pouco afeta suas chances de ter sucesso na vida. Assim, por exemplo, limitações cognitivas reveladas por experimentos de grande dificuldade podem não refletir uma característica relevante na vida diária. Da mesma forma, o sistema nervoso humano pode não ter um desempenho ótimo quando o critério de desempenho reflete uma preocupação moderna ao invés de um problema ecológico, como maximizar o ganho monetário, agir de maneira "lógica" ou mesmo buscar a verdade (HASELTON et al., 2009).

Em resumo, o processo evolutivo, sempre decorrente da interação dos seres vivos com o seu ambiente, nos deixa com o que podemos chamar de vieses cognitivos, ou seja, tendências no modo como percebemos o mundo e executamos as nossas ações, que favorecem o desempenho no ambiente no qual evoluímos e podem ou não ser ótimas em outros ambientes.

No presente trabalho, analisamos fenômenos cognitivos ligados à tomada de decisão e à atenção, em particular experimentos de escolha binária repetida, atenção 
seletiva espacial e o tempo de reação ao aparecimento abrupto de um alvo precedido por pista. Por estes fenômenos refletirem o que se supõe serem processos cognitivos fundamentais da percepção (que informação processamos e que informação ignoramos? como nosso sistema nervoso usa pistas espaciais?) e da ação (como decisões e resultados anteriores influenciam uma decisão posterior? como reagimos a estímulos que surgem abruptamente com diferentes frequências?), supõe-se que eles resultem de características surgidas no passado e preservadas até o presente por conferirem aos indivíduos que as portam uma vantagem na sobrevivência e sucesso reprodutivo, de forma que eles devem refletir vieses cognitivos. O nosso estudo de tomada de decisão é baseado na observação de que os seres humanos usam uma estratégia subótima no experimento de escolha binária repetida, e pretendemos mostrar que este resultado é devido a um viés cognitivo que leva à busca de padrões quando sequências de estímulos são observadas, mesmo quando padrões não existem. No caso da atenção seletiva, o fenômeno em si pode ser considerado um viés cognitivo que privilegia o processamento de estímulos mais relevantes, conforme nossos modelos ilustrarão. No caso do tempo de reação, veremos como o comportamento de seres humanos neste tipo de experimento pode ser replicado por modelos matemáticos do processo evolutivo somente quando dois fatores ambientais são introduzidos - ruído e seleção de ação. Isso nos sugere um certo tipo de ambiente para o qual os humanos estão adaptados, em que há ruído e é frequentemente necessário escolher entre várias possíveis ações apropriadas.

\subsection{Tomada de decisão}

Como dissemos, um dos aspectos abordados neste trabalho é a tomada de decisão. Em economia, política e ciências sociais, assume-se frequentemente que os seres humanos tomam decisões racionais, especialmente em situações simples que se repetem (VULKAN, 2000). A assim chamada teoria da escolha racional modela os seres humanos como agentes que procuram atingir seus objetivos egoístas da melhor maneira possível, ou seja, eles maximizam sua utilidade esperada (HINDMOOR, 2006). Esta teoria, muitas vezes em conjunto com a teoria dos jogos, é usada para prever o comportamento de indivíduos.

No entanto considere um experimento simples de tomada de decisão, onde um sujeito deve escolher entre duas alternativas - um problema de escolha binária. 
Quando se pede que ele preveja o próximo elemento na sequência de lançamentos de uma moeda, por exemplo, muitas pessoas acreditam que a chance de obter coroa aumenta depois de várias caras em série (BARHILLEL; WAGENAAR, 1991). Esta crença, conhecida como a falácia do jogador, é incorreta e pode levar ao desempenho subótimo.

Um experimento semelhante tem sido amplamente estudado desde os anos 1940 (VULKAN, 2000): a cada apresentação, uma luz pode piscar à esquerda ou à direita de uma tela. O sujeito tem a tarefa de prever de qual lado a luz vai piscar e é recompensado se a previsão se mostrar correta. Isto é repetido diversas vezes em uma série de apresentações, constituindo um experimento de escolha binária repetida. $\mathrm{O}$ lado em que a luz vai de fato aparecer é escolhido por um programa de computador a cada apresentação, independentemente das apresentações anteriores, com uma probabilidade constante para cada lado; por exemplo, a luz pode piscar à esquerda com probabilidade $2 / 3(67 \%)$ e à direita com probabilidade $1 / 3(33 \%)$. A natureza aleatória deste experimento torna impossível prever corretamente o tempo todo onde a luz vai piscar. Ao invés disso, é melhor escolher sempre o lado com a maior probabilidade (o lado em maioria). Esta estratégia é chamada de maximização e os sujeitos que maximizam estarão corretos em cerca de dois terços $(67 \%)$ das apresentações, que é o melhor que se pode fazer.

Seres humanos adultos em geral não maximizam (VULKAN, 2000). Eles tendem a escolher um dado lado com a mesma frequência com que a luz pisca daquele lado; por exemplo, se a luz pisca à direita em dois terços das tentativas, os sujeitos escolhem o lado direito em cerca de dois terços das tentativas. Esta estratégia é conhecida como pareamento de probabilidades e é sub-ótima - no exemplo anterior, os sujeitos que empregam pareamento de probabilidades estarão corretos só em cerca de cinco nonos $(56 \%)$ das tentativas, um nono (11\%) a menos que a maximização. Surpreendentemente, outros animals tais como ratos (PARDUCCI; POLT, 1958), macacos (BEHREND; BITTERMAN, 1961), pombos e peixes (GRAF; BULLOCK; BITTERMAN, 1964) tendem a maximizar. Assim, em um experimento de escolha binária repetida, os seres humanos não só não maximizam a sua utilidade esperada como também são passados para trás por ratos e peixes.

Uma possível pista de por que os seres humanos empregam tal estratégia surgiu logo no início do estudo deste experimento. Foi observado que depois realizar a tarefa os sujeitos relatavam que estavam procurando por um padrão ou lógica que 
regia a sequência de resultados das apresentações. Aparentemente eles não eram capazes de perceber que o resultado de cada apresentação não dependia do resultado das apresentações anteriores (FALK; KONOLD, 1997; VULKAN, 2000). Qualquer padrão que é capaz de descrever a sequência observada tem que levar em conta as frequências dos lados, assim, conforme os sujeitos testam padrões diferentes durante o experimento, eles podem estar fazendo pareamento de probabilidades. Baseando-se nestas ideias, foi proposto que o pareamento de probabilidades em seres humanos resultam de eles tentarem decodificar a sequência de apresentações em um padrão. Ou tros animais, tais como ratos e pombos, não têm a mesma habilidade de buscar padrões em sequências e adotam a estratégia mais simples de maximizar.

Ainda que esta explicação tenha um apelo intuitivo, a evidência que a apoia é em grande parte indireta. Por exemplo, foi mostrado que quando um algoritmo de pareamento de probabilidades é adicionado a "redes experts", elas têm um desempenho melhor em uma tarefa de aprendizado associativo por reforço (SABES; JORDAN, 1996). Gaissmaier e Schooler (2008) observaram que os sujeitos que faziam pareamento de probabilidades eram melhores em aprender um padrão do que aqueles que adotaram outras estratégias. Estes resultados sugerem que o pareamento de probabilidades é necessário para encontrar padrões. Dizer aos sujeitos que a sequência do experimento não segue um padrão melhora o desempenho deles, mas não a um nível ótimo (FANTINO; ESFANDIARI, 2002). Além disso, em um experimento de Unturbe e Corominas (2007), os sujeitos que relataram encontrar padrões complexos espúrios em uma tarefa de escolha binária repetida fizeram pareamento de probabilidades estrito e aqueles que não encontraram padrões tiveram um desempenho melhor, mas também não ótimo. Dada a falta de evidências convincentes, explicações alternativas se proliferaram, como por exemplo intuição matemática enganosa (KOEHLER; JAMES, 2009) e motivação e prática insuficientes (SHANKS; TUNNEY; MCCARTHY, 2002).

Outras explicações para o pareamento de probabilidades se baseiam nas vantagens que o pareamento de probabilidades, frequências ou recompensa esperada representa em cenários alternativos, diferentes da tarefa de escolha binária repetida descrita anteriormente, nos quais muitas vezes animais além dos seres humanos usam este tipo de estratégia (por exemplo, (GRAF; BULLOCK; BITTERMAN, 1964). Algumas destas explicações são: adaptação à incerteza (NIV et al., 2002; HARDYVALLÉE, 2007), adaptação ao forrageamento em um ambiente competitivo (SETH, 
2001, 2007) e o pareamento de probabilidades como uma consequência do aprendizado quase ótimo de estruturas (ACUÑA; SCHRATER, 2010). Podemos ver facilmente que, em um exemplo de cenário alternativo, o pareamento de frequência é a estratégia mais vantajosa: se recompensas estão distribuídas entre dois locais na proporção $80 \% / 20 \%$ e há vários animais tirando proveito destas recompensas, é vantajoso que os animais se distribuam entre os dois locais na mesma proporção. No entanto, devemos ter cuidado ao transpor uma explicação válida em um cenário alternativo para o experimento de escolha binária repetida, pois as diferenças podem ser muito importantes. Por exemplo, o cenário que acabamos de descrever envolve recompensa dividida entre dois locais e disputada por vários membros de uma mesma população.

Além disso, o comportamento ótimo neste cenário alternativo é previsto pela lei do pareamento (matching law - não confundir com probability matching) (HERRNSTEIN, 1961): um animal escolhe entre diversas opções em proporção às recompensas que ele recebeu destas opções no passado, em um pareamento de recompensa esperada. Esta lei prevê corretamente o comportamento de muitas espécies em vários casos em que eles fazem pareamento de probabilidades de forma ótima ou sub-ótima (por exemplo, MORRIS et al., 2006). Neste exemplo específico, os animais obtêm 80\% da recompensa em um dos locais e $20 \%$ da recompensa no outro local, por isso eles devem se dirigir a cada um destes locais nesta mesma frequência. Mas a lei do pareamento não prevê o uso do pareamento de probabilidades no caso do experimento de escolha binária repetida, e sim maximização. Se um animal fizer pareamento de probabilidades e a probabilidade de a recompensa estar em um determinado lado é $p$ $(0,5<p<1)$, a proporção de recompensas que o animal obterá naquele lado será $p^{2}$, que é sempre menor do que $p$. Somente o animal que maximiza obedece à lei do pareamento, pois obtém $100 \%$ das recompensas do lado que ele escolhe com probabilidade $100 \%$. Assim, podemos usar a lei do pareamento para entender o cenário acima, mas a mesma lei não explica o comportamento de seres humanos em experimentos de escolha binária repetida.

De qualquer modo, podemos tirar proveito de uma visão comum a muitas destas explicações: a de que o pareamento de probabilidades deve ter sido uma estratégia adequada para sobreviver no ambiente em que os seres humanos evoluíram, mas não no ambiente artificial de um laboratório, onde ela parecerá sub-ótima. 


\subsubsection{Cadeias de Markov e medidas de informação}

Na discussão acima, foi mencionada a busca de padrões como uma explicação possível de por que os seres humanos usam o pareamento de probabilidades no experimento de escolha binária repetida. Se a explicação for verdadeira, a fim de estudar mais profundamente este comportamento, devemos primeiro responder uma pergunta básica: o que é um padrão? Temos uma noção intuitiva do que é um padrão, mas a literatura sobre pareamento de probabilidades não nos dá uma definição precisa, matemática do conceito.

Um exemplo simples e intuitivo de padrão totalmente previsível é uma sequência binária em que os resultados D (direita) e E (esquerda) se alternam: DEDEDEDEDEDEDEDE ... Para prever qual é o próximo elemento da sequência com toda a certeza, é suficiente saber qual é o elemento anterior da sequência. Se o elemento anterior é $\mathrm{D}$, o próximo elemento é $\mathrm{E}$. Se o elemento anterior é $\mathrm{E}$, o próximo elemento é $\mathrm{D}$.

A cada apresentação de um experimento clássico de escolha binária repetida, o voluntário tenta prever em qual lado da tela o próximo estímulo será exibido e toda a informação que ele pode usar para fazer esta escolha vem dos estímulos apresentados anteriormente, até onde o voluntário consegue se lembrar. Assim chegamos ao conceito de cadeias de Markov. 
Tabela 1 - Descreve o padrão DEDEDEDE ... como uma cadeia de Markov de ordem 1.

\begin{tabular}{l|l|l|} 
& \multicolumn{1}{c}{$\mathrm{D}$} & \multicolumn{1}{l}{$\mathrm{E}$} \\
$\mathrm{D}$ & 0,0 & 1,0 \\
$\mathrm{n}$ & 1,0 & 0,0 \\
\cline { 2 - 3 } & &
\end{tabular}

Cadeias de Markov ou cadeias de Markov de ordem 1, como iremos chamá-las, são sequências de variáveis aleatórias nas quais o valor do elemento seguinte só depende do valor do elemento anterior. Por exemplo, o resultado de cada apresentação na tarefa de escolha binária repetida pode ser representado por uma variável aleatória $X_{i}$, onde $i$ é o número da apresentação começando em 1 . O valor de $X_{i}$ será E se o estímulo $i$ vier à esquerda e $\mathrm{D}$ de o estímulo $i$ vier à direita. Se o valor da próxima apresentação $X_{i+1}$ não depende de nenhum outro valor além de $X_{i}$, então este experimento pode ser completamente descrito por uma cadeia de Markov de ordem 1. $\mathrm{O}$ caso do exemplo de padrão acima (D's e E's que se alternam) pode ser completamente descrito por uma cadeia de Markov de ordem 1. Para tanto, usamos uma matriz que dá as probabilidades do próximo elemento, nas colunas, em função do elemento anterior, nas linhas. Esta matriz é chamada de matriz de transição. Assim, o exemplo em que D's e E's se alternam pode ser descrito pela Tabela 1. A primeira linha descreve o que acontece quando o elemento anterior é $\mathrm{D}$ e a segunda linha descreve o que acontece quando o elemento anterior é E. As probabilidades de o próximo elemento ser D são dadas na primeira coluna e as probabilidades de o próximo elemento ser $\mathrm{E}$ são dadas na segunda coluna. A tabela nos informa, por exemplo, que quando o elemento anterior é E, o próximo elemento sempre é D (probabilidade 1,0 na segunda linha, primeira coluna).

De particular relevância para este trabalho são as cadeias de Markov estacionárias. Um processo estacionário é aquele em que a probabilidade de se observar uma certa subsequência de qualquer tamanho (por exemplo, DED) é igual em qualquer posição da sequência. No exemplo dado, se uma sequência de apresentações é gerada por uma cadeia de Markov estacionária, a probabilidade de que os três primeiros resultados sejam DED é igual à probabilidade de que o centésimo, o centésimo primeiro e o centésimo segundo resultados sejam DED e assim para todo conjunto de três apresentações consecutivas. Para que uma cadeia de Markov de ordem 1 seja estacionária, é necessário não somente dar a matriz de transição da cadeia, mas também a distribuição estacionária, ou seja, as probabilidades de D e E, para que seja sorteado o 
Tabela 2 - Descreve uma sequência probabilística como uma cadeia de Markov de ordem 1.

$$
\begin{array}{l|l|l|} 
& \multicolumn{1}{c}{\mathrm{D}} & \multicolumn{1}{c}{\mathrm{E}} \\
\mathrm{D} & 0,3 & 0,7 \\
\mathrm{n} & 0,7 & 0,3 \\
\hline
\end{array}
$$

resultado da primeira apresentação de forma que as probabilidades de D e E na primeira apresentação sejam iguais às probabilidades de D e E em qualquer posição da sequência. Já os resultados das apresentações subsequentes são obtidos diretamente pela a matriz de transição. Pelas propriedades matemáticas das cadeias de Markov de ordem 1, a distribuição estacionária é igual à frequência de $\mathrm{D}$ e E em uma sequência muito longa. No caso do exemplo acima (Tabela 1), vê-se facilmente que a frequência de $\mathrm{D}$ e de E na sequência é 0,5 , portanto a probabilidade de o primeiro elemento da sequência ser $\mathrm{D}$ ou $\mathrm{E}$ também deve ser 0,5 se quisermos que a sequência seja estacionária. Em toda a discussão sobre cadeias de Markov de agora em diante, consideraremos que as sequências são estacionárias.

As cadeias de Markov não descrevem somente padrões determinísticos como o da Tabela 1. A Tabela 2 dá um exemplo de padrão probabilístico. Um exemplo de sequência gerada por esta matriz é DEDEEDEDDEDDDEDEDEDE ... As letras D e E têm uma tendência a se alternarem, mas às vezes se repetem. Intuitivamente tendemos a achar que a primeira sequência "tem mais padrão", ou segue um padrão mais previsível, do que a segunda.

Para medir o grau de previsibilidade de uma cadeia de Markov de ordem 1 de forma precisa, usamos o conceito de entropia e informação. A informação de um evento é definida por:

$$
I(p)=-\log (p)
$$

onde $p$ é a probabilidade de um evento acontecer e log é o logaritmo na base 2. A informação é medida em bits. Quanto mais improvável é um evento, mais informação ele contém.

Dada uma variável de Bernoulli $X$, que pode assumir só dois valores com probabilidades $p$ e $q$, como no caso em que estamos interessados, a entropia desta variável é dada por:

$$
H(X)=-p \log (p)-q \log (q)
$$


A entropia, assim como a informação, é medida em bits. Pela fórmula, a entropia é a média da informação contida nos resultados do experimento ponderada pela probabilidade de cada resultado. A Tabela 3 nos dá o valor da entropia para diferentes valores de $p$ (já que $q=1-p$ ). É possível observar que a entropia é máxima quando $p=0,5$ e mínima quando $p=0$ ou quando $p=1$. Desta forma, a entropia mede o grau de incerteza associado àquele experimento. Quando $p=0,5$, a variável aleatória pode assumir qualquer valor com igual probabilidade; é a situação em que realmente não se pode prever o que vai acontecer, por isso a entropia é máxima (1 bit). Quando $p=0$ ou $p=1$, pode-se prever o resultado do experimento com certeza, por isso a entropia é 0 bits.

É possível medir a entropia de duas variáveis aleatórias ao mesmo tempo, por exemplo, de duas apresentações de um experimento de escolha binária repetida, representados pelas variáveis aleatórias $X_{1}$ e $X_{2}$, que podem assumir cada uma o valor D ou E. Para isso, usa-se a probabilidade conjunta dos dois experimentos como mostrado abaixo:

$$
\begin{aligned}
& H\left(X_{1}, X_{2}\right)=-p\left(X_{1}=D, X_{2}=D\right) \log \left(p\left(X_{1}=D, X_{2}=D\right)\right) \\
& -p\left(X_{1}=D, X_{2}=E\right) \log \left(p\left(X_{1}=D, X_{2}=E\right)\right) \\
& -p\left(X_{1}=E, X_{2}=D\right) \log \left(p\left(X_{1}=E, X_{2}=D\right)\right) \\
& -p\left(X_{1}=E, X_{2}=E\right) \log \left(p\left(X_{1}=E, X_{2}=E\right)\right)
\end{aligned}
$$

De maneira semelhante, pode-se medir a entropia para mais de duas apresentações. Chamamos estas entropias de entropias conjuntas ou simplesmente entropias

Tabela 3 - Entropia de uma variável aleatória de Bernoulli $X$ em função do valor de p.

\begin{tabular}{c|c}
\hline $\boldsymbol{p}$ & $\boldsymbol{H}(\boldsymbol{X})$ \\
\hline 0,0 & 0,0000 \\
\hline 0,1 & 0,4690 \\
\hline 0,2 & 0,7219 \\
\hline 0,3 & 0,8813 \\
\hline 0,4 & 0,9710 \\
\hline 0,5 & 1,0000 \\
\hline 0,6 & 0,9710 \\
\hline 0,7 & 0,8813 \\
\hline 0,8 & 0,7219 \\
\hline 0,9 & 0,4690 \\
\hline 1,0 & 0,0000 \\
\hline
\end{tabular}


Tabela 4 - Fórmulas correspondentes às diferentes medidas de entropia e taxa de entropia.

\begin{tabular}{l|l}
\hline Entropia de ordem 0 & $\mathrm{H}\left(\mathrm{X}_{1}\right)$ \\
\hline Entropia de ordem 1 & $\mathrm{H}\left(\mathrm{X}_{2}, \mathrm{X}_{1}\right)$ \\
\hline Entropia de ordem 2 & $\mathrm{H}\left(\mathrm{X}_{3}, \mathrm{X}_{2}, \mathrm{X}_{1}\right)$ \\
\hline Entropia de ordem 3 & $\mathrm{H}\left(\mathrm{X}_{4}, \mathrm{X}_{3}, \mathrm{X}_{2}, \mathrm{X}_{1}\right)$ \\
\hline Taxa de entropia de ordem 1 & $\mathrm{H}\left(\mathrm{X}_{2} \mid \mathrm{X}_{1}\right)$ \\
\hline Taxa de entropia de ordem 2 & $\mathrm{H}\left(\mathrm{X}_{3} \mid \mathrm{X}_{2}, \mathrm{X}_{1}\right)$ \\
\hline Taxa de entropia de ordem 3 & $\mathrm{H}\left(\mathrm{X}_{4} \mid \mathrm{X}_{3}, \mathrm{X}_{2}, \mathrm{X}_{1}\right)$ \\
\hline
\end{tabular}

de ordem 1 (para duas apresentações consideradas ao mesmo tempo), 2 (para 3 apresentações consideradas ao mesmo tempo), etc (Tabela 4). A entropia de somente uma apresentação é a entropia de ordem 0.

Como em uma cadeia de Markov de ordem 1 o resultado do próximo experimento depende do resultado do experimento anterior, um conceito útil é o de entropia condicional de ordem 1 ou taxa de entropia de ordem 1. Ela é definida por:

$$
H\left(X_{2} \mid X_{1}\right)=p\left(X_{1}=D\right) H\left(X_{1} \mid X_{2}=D\right)+p\left(X_{1}=E\right) H\left(X_{1} \mid X_{2}=E\right)
$$

Ou seja, a entropia condicional da variável $X_{2}$ dado $X_{1}$ é a média das entropias de $X_{2}$, calculadas dado que $X_{1}$ assume um determinado valor, ponderadas pela probabilidade de $X_{1}$ assumir este determinado valor. A taxa de entropia de ordem 2 é a entropia condicional de $X_{3}$ dado $X_{2}$ e $X_{1}$. De forma análoga, pode-se calcular a taxa de entropia de ordens maiores (Tabela 4). 
Como exemplo, vamos calcular os diferentes tipo de entropia para a sequência determinística dada pela Tabela 1 e comparar estes resultados com a sequência probabilística dada pela Tabela 2. Esta comparação é feita na Tabela 5.

Olhando para a taxa de entropia de ordem 1 para a primeira sequência, confirmamos que ela é determinística - tem entropia 0 , ou seja, não há nenhuma incerteza quando se sabe o resultado do experimento anterior. Ao se conhecer os resultados dos dois ou três últimos experimentos (taxas de entropia de ordem 2 ou 3), da mesma forma é possível prever com certeza o próximo experimento. A entropia de ordem 0 para esta sequência é 1 , pois para cada apresentação, sem conhecimento das apresentações anteriores, as probabilidades de D e E são as mesmas. As entropias de ordem 1, 2 e 3 também valem 1,0, pois toda a informação está contida em uma apresentação; sabendo-se um resultado, é possível prever os outros.

Para a segunda sequência, cuja matriz de transição é dada pela Tabela 2, a taxa de entropia de ordem 1 vale 0,88 . Ela não vale 1 - incerteza total - porque, dado o resultado anterior, existe um valor para o próximo resultado que é mais provável do que o outro; ela não vale 0 - sequência totalmente previsível - porque mesmo conhecendo o resultado anterior não se pode prever com certeza o próximo resultado. As taxas de entropia de ordens maiores valem 0,88 , assim como a taxa de entropia de ordem 1, pois em uma cadeia de Markov de ordem 1, o próximo elemento só depende do elemento imediatamente anterior; conhecer outros elementos anteriores não acrescenta informação alguma, não diminui a entropia do próximo elemento. A entropia de ordem 0 para esta sequência é 1,0 pois as probabilidades de D e E são as mesmas. As entropias de ordem 1, 2 e 3 vão crescendo em incrementos de 0,88 , que é justa-

Tabela 5 - Cálculo de diversas medidas de entropia para duas cadeias de Markov.

\begin{tabular}{l|r|rr}
\hline & \multicolumn{2}{|c|}{ Sequência da Tabela 1 } & \multicolumn{2}{c}{ Sequência da Tabela 2 } \\
\hline Exemplo de sequência & DEDEDEDEDE... & DEDEEDEDDE ... \\
\hline Entropia de ordem 0 & 1,00 & 1,00 \\
\hline Entropia de ordem 1 & 1,00 & 1,88 \\
\hline Entropia de ordem 2 & 1,00 & 2,76 \\
\hline Entropia de ordem 3 & 1,00 & 3,64 \\
\hline Taxa de entropia de ordem 1 & 0,00 & 0,88 \\
\hline Taxa de entropia de ordem 2 & 0,00 & 0,88 \\
\hline Taxa de entropia de ordem 3 & 0,00 & 0,88 \\
\hline
\end{tabular}


Tabela 6 - Cálculo de diversas medidas de entropia para um experimento com $70 \%$ à esquerda.

\begin{tabular}{l|r}
\hline Exemplo de sequência & DEEDEEEEDE... \\
\hline Entropia de ordem 0 & \\
\hline Entropia de ordem 1 & 0,88 \\
\hline Entropia de ordem 2 & 1,76 \\
\hline Entropia de ordem 3 & 2,65 \\
\hline Taxa de entropia de ordem 1 & 3,53 \\
\hline Taxa de entropia de ordem 2 & 0,88 \\
\hline Taxa de entropia de ordem 3 & 0,88 \\
\hline
\end{tabular}

mente o valor da taxa de entropia (daí vem o nome "taxa de entropia"). De fato, a entropia de ordem $n$ é igual à entropia de ordem $(n-1)$ somada à taxa de entropia de ordem n:

$$
H\left(X_{n}, X_{n-1}, \ldots, X_{1}\right)=H\left(X_{n-1}, X_{n-2}, \ldots, X_{1}\right)+H\left(X_{n} \mid X_{n-1}, X_{n-2}, \ldots, X_{1}\right)
$$

A entropia conjunta cresce porque a incerteza em se prever o resultado de duas, três ou mais apresentações é cada vez maior.

Além de cadeias de Markov de ordem 1, podemos considerar cadeias de Markov de outras ordens. No experimento clássico de escolha binária repetida, cada apresentação na sequência pode ter um resultado ou outro de acordo com uma probabilidade fixa $-70 \%$ à esquerda, por exemplo - que não depende de nenhuma apresentação anterior. Este experimento pode ser descrito por uma cadeia de Markov de ordem 0 e podemos calcular as entropias e taxas de entropias (Tabela 6).

As taxas de entropia deste experimento são iguais às da coluna mais à direita da Tabela 5. A diferença é que, naquele experimento, o primeiro elemento pode ser $\mathrm{D}$ ou E com igual probabilidade. Neste experimento, o primeiro elemento é E com probabilidade 0,7 , por isso a entropia de ordem 0 é menor do que 1,0. As entropias de ordem superior crescem à taxa de 0,88 .

Tabela 7 - Exemplo de matriz de transição para uma cadeia de Markov de ordem 2.

\begin{tabular}{c|l|l|}
\multicolumn{1}{c}{} & \multicolumn{1}{c}{$\mathrm{D}$} & \multicolumn{1}{l}{$\mathrm{E}$} \\
\cline { 2 - 3 } DD & 0,0 & 1,0 \\
\cline { 2 - 3 } DE & 0,0 & 1,0 \\
\cline { 2 - 3 } ED & 0,0 & 1,0 \\
EE & 1,0 & 0,0 \\
\cline { 2 - 3 } & &
\end{tabular}


Tabela 8 - Cálculo de diversas medidas de entropia para o experimento da Tabela 7.

\begin{tabular}{|c|c|}
\hline Exemplo de sequência & EEDEEDEED ... \\
\hline Entropia de ordem 0 & 0,92 \\
\hline Entropia de ordem 1 & 1,58 \\
\hline Entropia de ordem 2 & 1,58 \\
\hline Entropia de ordem 3 & 1,58 \\
\hline Taxa de entropia de ordem 1 & 0,67 \\
\hline Taxa de entropia de ordem 2 & 0,00 \\
\hline Taxa de entropia de ordem 3 & 0,00 \\
\hline
\end{tabular}

Em uma cadeia de Markov de ordem 2, o resultado de cada apresentação depende das duas apresentações anteriores. A Tabela 7 dá um exemplo de matriz de transição para uma cadeia de Markov de ordem 2.

Há uma linha da matriz para cada combinação de duas apresentações anteriores e uma coluna para cada possível valor da próxima apresentação. Como todas as probabilidades são zeros e uns, esta cadeia é totalmente previsível. Um exemplo de sequência é EEDEEDEEDEEDEED ... Para que a matriz seja estacionária, a distribuição estacionária é a probabilidade conjunta dos dois primeiros elementos. Como a sequência consiste em uma repetição do padrão EED, pode-se ver facilmente que a distribuição estacionária é dada por $(\mathrm{p}(\mathrm{DD})=0 ; \mathrm{p}(\mathrm{DE})=0,33$; $\mathrm{p}(\mathrm{ED})=0,33 ; \mathrm{p}(\mathrm{EE})=$ $0,33)$.

As entropias e taxas de entropias para esta cadeia são dadas na Tabela 8. A taxa de entropia de ordem 1 não é zero, pois não se pode prever qual será o próximo resultado só com base no resultado anterior. Já as taxas de entropia de ordem 2 em diante são 0 , ou seja, a sequência é totalmente previsível ao se saber pelo menos os dois resultados anteriores. Pode-se descobrir a ordem de uma cadeia de Markov pelas taxas de entropia, pois as taxas de entropia de ordem crescente têm valores decrescentes; a partir de uma determinada ordem, o valor da taxa de entropia não vai mais diminuir e esta é a ordem da cadeia de Markov. No caso da Tabela 8, confirmamos que a partir da ordem 2, a taxa de entropia não diminui.

De forma análoga ao que foi mostrado, podemos considerar cadeias de Markov de ordem $3,4,5, \ldots$ e medir suas entropias e taxas de entropia. 


\subsection{Alocação espacial da atenção}

No presente trabalho, além de estudarmos esses aspectos da tomada de decisão, também estudamos um aspecto da percepção: a atenção seletiva. Ela é definida como a capacidade do sistema nervoso em focalizar certos aspectos da percepção sensorial, já que, a cada momento, apenas uma parte dos diversos estímulos captados pelo sistema nervoso se torna consciente. Um exemplo é o "efeito coquetel": no ambiente barulhento e confuso de uma festa, é possível focar a atenção a uma única conversa (CHERRY; TAYLOR, $1954^{1}$ apud GAZZANIGA; IVRY; MANGUN, 1998).

Desde o início do estudo da atenção em humanos, foi sugerido que a seleção dos estímulos sensoriais é necessária pois existe uma quantidade limitada de recursos computacionais disponível para processar todos os estímulos captados pelo sistema nervoso (BROADBENT, 1958). Quando há uma sobrecarga do canal sensorial, superando a capacidade de processamento, mecanismos de seleção são utilizados para assegurar o processamento dos estímulos de maior prioridade (DESIMONE; DUNCAN, 1995).

Com base nessa teoria, podemos imaginar que os mecanismos de atenção seletiva surgiram ao longo da evolução porque o sistema nervoso possui capacidade limitada e existem pressões evolutivas que se opõem ao aumento de capacidade de modo a superar essas limitações. De fato, o tecido nervoso é energeticamente caro e animais com menos neurônios têm uma vantagem no consumo de energia (HERCULANOHOUZEL, 2011).

Essas conclusões também são apoiadas pelo trabalho de vida artificial desenvolvido por Bartolomeo, Pagliarini e Parisi (2002). Estes autores realizaram simulações nas quais os recursos de processamento eram escassos e os estímulos visuais, complexos, e como resultado, a porção central do campo visual se tornava uma "fóvea", ou seja, uma região de maior acurácia visual em comparação com a periferia. Os organismos com poucos recursos computacionais detectavam a presença de um objeto nas posições periféricas do campo visual, mas não eram capazes de identificá-lo sem primeiro executar um movimento de forma a centralizá-lo. Os movimentos de orientação do corpo para fovear um estímulo são vistos pelos autores como uma incorporação dos processos cognitivos de atenção seletiva.

${ }^{1}$ CHERRY, E. C.; TAYLOR, W. K. Some further experiments on the recognition of speech with one and two ears. Journal of the Acoustical Society of America, v. 26, p. 554-559, 1954. 
Mais recentemente, foi proposto que a seleção não resulta de limitações na capacidade de processamento e sim do fato de que o planejamento de uma ação requer a inibição de estímulos irrelevantes a fim de que a ação tomada seja baseada apenas nos estímulos relevantes (ALLPORT, 1987).

De acordo com essa teoria, chamada de "seleção-para-a-ação", a limitação de capacidade é causada pela necessidade de seleção e não o contrário. Como exemplo, vamos considerar o seguinte experimento (DAYAN; KAKADE; MONTAGUE, 2000): toda vez que um animal irá receber comida, uma luz azul se acende. No ambiente onde ele vive, também há uma luz amarela, que se acende e se apaga de forma independente da entrega de comida. Quando o animal vai prever a quantidade de comida que lhe será entregue, para que a previsão seja acurada, ela não pode ser baseada na luz amarela, pois esta não tem nenhum valor preditivo. Os circuitos neuronais que fazem a previsão não podem ser influenciados pela luz amarela, por isso este estímulo deve ser inibido. O animal deve focalizar apenas a luz azul. Com base na teoria de seleção-para-a-ação, podemos imaginar que a atenção seletiva surgiu pelo fato de que, no ambiente, nem todos os estímulos fornecem informações relevante para a ação. O animal cujo sistema nervoso era capaz de inibir os estímulos irrelevantes era capaz de agir de forma mais adaptativa do que os outros e por isso tinha uma maior chance de sobreviver.

\subsubsection{Mensuração da atenção: detectabilidade e tempos de reação}

A fim de testar estas ideias e estudar a atenção em geral, dois tipos de medidas são bastante utilizados em experimentos com seres humanos e outros animais: medidas de detectabilidade e medidas de tempo de reação.

\subsubsection{Detectabilidade}

Para saber como os animais processam os estímulos captados pelo seu sistema nervoso, métodos da teoria de detecção de sinais podem ser usados. A teoria de detecção de sinais estuda experimentos de detecção, nos quais estímulos de baixa intensidade devem ser distinguidos de um fundo ruidoso (MACMILLAN; CREELMAN, 2004). No caso mais simples, só um estímulo está presente e o componente sensorial do desempenho de um sujeito é descrito pela detectabilidade ou d'. A detectabilidade 
é uma função da taxa de acertos (dadas as apresentações em que o sinal está presente, a taxa de acertos é a fração destas apresentações em que o sujeito corretamente detectou o sinal) e da taxa de falsos alarmes (dadas as apresentações em que o sinal está ausente, a taxa de falsos alarmes é a fração destas apresentações em que o sujeito erroneamente detectou o sinal). A definição de detectabilidade, ou d', é:

$$
d^{\prime}=z(H)-z(F)
$$

onde $H$ é a taxa de acertos, $F$ é a taxa de falsos alarmes e $z$ é a função inversa da função de distribuição normal padrão cumulativa. Uma detectabilidade alta resulta da capacidade em detectar o sinal quando ele está presente (alta taxa de acertos) e, ao mesmo tempo, em não detectar o sinal quando ele está ausente (baixa taxa de falsos alarmes).

\subsubsection{Tempos de reação}

Quando queremos acender a lâmpada em um quarto escuro, pressionamos o interruptor e a lâmpada se acende quase instantaneamente. Porém, quando nós, seres humanos, devemos reagir a um estímulo visual o mais rapidamente possível, mesmo nos casos mais simples, o tempo que levamos para produzir uma resposta excede $100 \mathrm{~ms}$. Essa diferença se deve principalmente à enorme complexidade dos sistemas sensorial e motor humanos quando comparado ao simples circuito que conecta um interruptor a uma lâmpada. Estes sistemas possibilitam o processamento de entradas diversas (não somente as duas posições de um interruptor) e a geração de uma resposta, dentre muitas possíveis (não somente "acende" e "apaga"), que seja adequada àquele momento. 
Como computações neuronais diferentes, que levam mais ou menos tempo, são realizadas para processar diferentes estímulos e gerar diferentes respostas, o tempo que levamos para emitir uma resposta a um estímulo varia de acordo com a tarefa. Por exemplo, desde os experimentos clássicos realizados por Posner (1980), foi mostrado que reagimos mais rapidamente ao surgimento abrupto de um estímulo quando o estímulo surge em um local esperado. No experimento mais simples deste tipo, chamado de experimento de tempo de reação simples, os voluntários fixam seu olhar em um ponto de fixação no centro da tela (Figura 2). A seguir, em um local próximo ao centro da tela, aparece uma pista, que é um sinal apontando para um lado ou para o outro lado ou não apontando para nenhum lado. O sujeito deve prestar atenção ao local apontado pela pista, se ela aponta para um dos lados, ou distribuir sua atenção de forma a abranger ambos os lados, se a pista não aponta para nenhum lado. Após decorrido um intervalo de tempo de duração variável, aparece em um dos lados da tela um estímulo (o quadrado nas figuras), chamado de alvo. O sujeito deve responder o mais rapidamente possível ao alvo, apertando um botão, por exemplo. O resultado do experimento é obtido medindo-se o tempo que decorre entre o aparecimento do alvo e a coleta da resposta, chamado de tempo de reação. Como só existe um tipo de resposta considerado neste experimento, o tempo de reação é dito "simples". Se o sujeito tivesse que, por exemplo, apertar um botão à direita toda vez que o alvo aparecesse à direita e apertar um botão à esquerda toda vez que o alvo aparecesse à esquerda, o tempo de reação seria "de escolha".

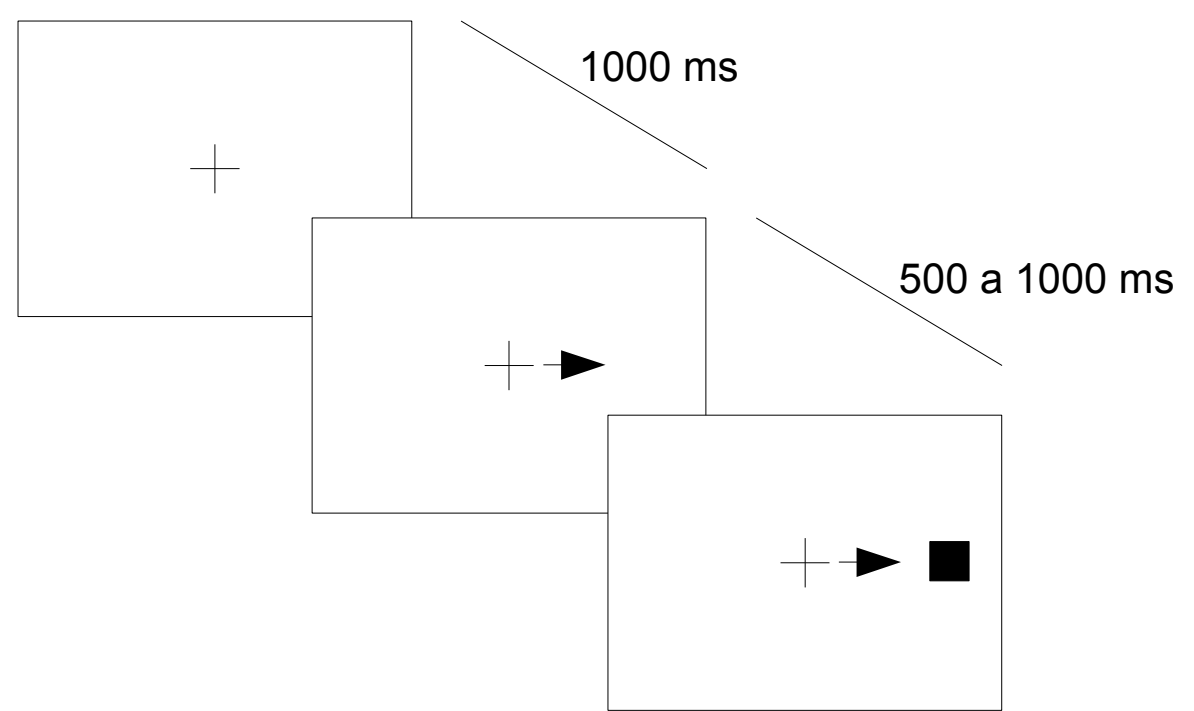

Figura 2 - Esquema de um experimento de tempo de reação ao aparecimento abrupto de um alvo (quadrado preto) precedido por pista (seta apontando para a direita). 


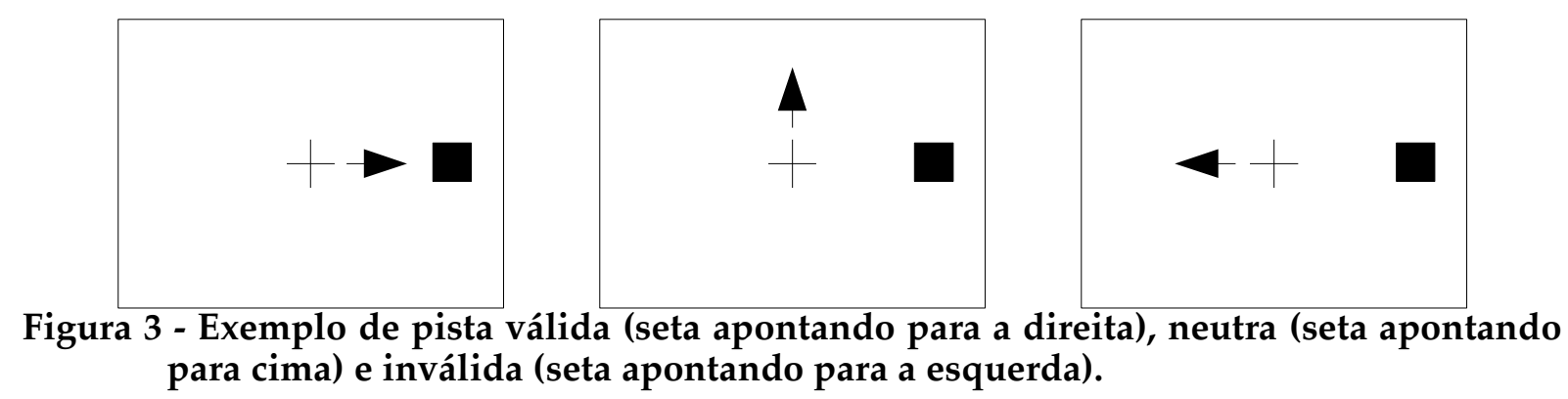

Se o alvo apareceu do lado apontado pela pista, a pista é dita válida. Se o alvo apareceu do lado contrário ao apontado pela pista, a pista é dita inválida. Se a pista não aponta para um dos lados, ela é dita neutra (Figura 3). Para que a informação fornecida pela pista tenha valor ao sujeito do experimento, a pista deve ser válida mais frequentemente do que inválida. Posner (1980), por exemplo, fez com que a razão entre o número de pistas válidas, neutras e inválidas fosse 8:5:2.

Ele então observou que o tempo de reação dos voluntários é menor quando a pista é válida, maior quando a pista é inválida e intermediário quando a pista é neutra. Assim, concluiu-se que se um estímulo surge abruptamente em um local do espaço no qual estamos prestamos atenção, responderemos mais rapidamente a este estímulo do que a outros estímulos em outros locais não atendidos.

Para explicar os resultados deste experimento, Posner (1980) retomou a ideia de que a atenção mobiliza recursos limitados do sistema nervoso para o processamento dos estímulos mais importantes (BROADBENT, 1958). Por esta teoria, o papel da atenção seria o de alocar recursos para o processamento sensorial dos estímulos que aparecem no local indicado pela pista, já que o alvo tem alta probabilidade de aparecer ali, e deste modo acelerar a geração de uma resposta apropriada a eles. Aos outros locais do espaço, será alocado o restante dos recursos.

No entanto, mesmo anteriormente aos trabalhos citados de Posner e Broadbent, já se destacava o papel da atenção em filtrar estímulos "distratores", irrelevantes para a execução da tarefa. Eriksen e Hoffman (1973), por exemplo, observaram que a presença de estímulos distratores em local próximo ao local de aparecimento do alvo aumenta o tempo de reação. Dosher e Lu (2000) e Lu, Lesmes e Dosher (2002) realizaram experimentos de discriminação nos quais a atenção, manipulada pela presença de pistas válidas e inválidas, só teve uma influência significativa no resultado do experimento na presença de ruído externo. Shiu e Pashler (1994) propuseram que a pista válida traz benefícios em contextos ruidosos independentemente da limitação de 
recursos, pois a percepção pode focar-se no local apontado pela pista e inibir o processamento de estímulos em outro locais, diminuindo assim a probabilidade de que um estímulo distrator produza uma resposta incorreta.

Esta proposta destaca o papel da atenção na seleção da ação. Como já vimos, Allport (1987) propôs que a atenção filtra os estímulos irrelevantes para que somente os estímulos relevantes influenciem a ação do indivíduo. Da mesma forma, a atenção, ao se focar no provável local onde o estímulo relevante irá surgir, também aumenta a probabilidade de que a resposta apropriada a este estímulo seja gerada. O modelo matemático proposto por Reynolds e Heeger (2009) mostra como uma grande variedade de efeitos e mecanismos atencionais presentes na literatura (facilitação dos estímulos atendidos, inibição de ruído externo, mudanças no contraste, mudanças no campo receptivo dos neurônios etc.) pode resultar de um mesmo processo através do qual o sistema nervoso aumenta a sensibilidade a estímulos fracos porém relevantes e reduz o impacto de estímulos irrelevantes à tarefa.

Assim, a partir da literatura sobre o tema, pode-se juntar várias propostas de quais foram os fatores evolutivos e ambientais que influenciaram o surgimento de mecanismos atencionais, responsáveis por gerar os resultados em experimentos de tempo de reação como os acima mencionados. Resumindo a discussão acima, estes fatores são:

1. Limitação de recursos: o sistema nervoso não é capaz de processar ao mesmo tempo de forma adequada estímulos sensoriais provenientes de várias regiões do espaço. Assim, ele se foca na região apontada pela pista, pois é ali que o alvo tem maior probabilidade de aparecer. Os estímulos que caírem nesta região serão processados rapidamente e os estímulos que caírem em outras regiões serão processados mais lentamente.

2. Presença de ruído: para que o sistema nervoso responda somente ao alvo, é importante diferenciá-lo do ruído. Um estímulo que cai na região apontada pela pista tem grande probabilidade de ser alvo e não ruído e por isso ele é processado mais rapidamente do que um estímulo que cai em uma outra região e portanto tem grande probabilidade de ser ruído e não alvo.

3. Seleção da ação: para que a resposta a um estímulo seja selecionada de forma apropriada, é necessário que o animal perceba os estímulos corretamente. Quando a pista aponta para um local do espaço, o sistema nervoso já pode 
preparar uma resposta apropriada ao aparecimento do alvo (ao invés de ruído) naquele local do espaço e por isso o tempo de reação é menor.

\subsection{Modelos cognitivos}

Para que possamos entender como estes vieses influenciam o nosso comportamento, devido à complexidade do sistema nervoso, é necessário criar modelos mais simples.

Muitos dos modelos propostos em neurociências são conceituais, não quantitativos, tornando difícil a sua análise por métodos matemáticos e estatísticos. Além disso, eles são muitas vezes baseados nas relações entre módulos de processamento abstratos e não fazem referência a conjuntos neuronais do sistema nervoso, o que limita a sua utilização no entendimento dos resultados obtidos em neurofisiologia.

Um outro tipo de modelo que vem sendo utilizado para estudar a cognição é baseado em redes neurais artificiais. As redes neurais são compostas por unidades de processamento simples, chamadas de nós, inspiradas nas células nervosas. Os nós estão conectados por sinapses, cuja força é determinada por pesos sinápticos. Estes, por sua vez, podem ser modificados em função dos estímulos que as redes neurais recebem, permitindo, assim, que elas tenham a capacidade de aprender. As redes neurais modelam o sistema nervoso de forma explícita e bem definida; assim os resultados das simulações podem ser analisados por métodos quantitativos. Além disso, sua estrutura foi baseada explicitamente na estrutura neuronal do sistema nervoso. Por isso, esta ferramenta tem vantagens no entendimento de fenômenos cognitivos complexos em relação aos modelos verbais comumente propostos (PARISI, 2001).

Em geral, nos modelos cognitivos, os mecanismos são introduzidos manualmente, de forma que o pesquisador obtenha resultados semelhantes àqueles obtidos em experimentos com animais. Eles se concentram em tentar elucidar como ocorre o processamento da informação. Para o estudo de vieses cognitivos, no entanto, é necessário abordar a cognição como um fenômeno biológico, que afeta as chances de sobrevivência de um animal. Um método de estudo denominado vida artificial, que vem sendo utilizado mais recentemente para estudar diversos aspectos cognitivos do sistema nervoso (PARISI, 1997; WATTS, 1998; HOKKANEN, 1999; PARISI, 2001), usa justamente esta abordagem; em modelos de vida artificial, o sistema nervoso é simulado utilizando redes neurais artificiais inseridas em corpos físicos que existem em 
ambientes físicos (PARISI, 1997). Também é possível simular o processo de evolução biológica. A probabilidade de um animal artificial se reproduzir depende do seu desempenho ou grau de adaptação, que resulta da interação do animal com o ambiente: os animais mais bem adaptados ao ambiente têm uma maior probabilidade de se reproduzir. Em experimentos de vida artificial aplicada às neurociências, a evolução ocorre nas estruturas das redes neurais, tornando possível o estudo da evolução do sistema nervoso e portanto o estudo do surgimento de vieses cognitivos.

Se for possível obter, pelo processo de evolução, redes neurais com propriedades cognitivas semelhantes à dos animais biológicos, a análise dos resultados deve ser feita de forma a tornar possível uma comparação entre aqueles resultados e resultados de experimentos com animais biológicos. No entanto, os métodos psicofísicos, amplamente utilizados na análise do comportamento de animais biológicos, ainda têm uso limitado em estudos de vida artificial (FLOREANO; URZELAI, 2000). Em contraste, nos trabalhos com animais biológicos, muitas funções cognitivas, como a atenção, são bem caracterizadas por medidas psicofísicas. Em nosso laboratório, estes métodos vêm sendo utilizados para estudar fenômenos perceptuais em seres humanos, como o efeito flash lag e a percepção de tempo (BALDO; KLEIN, 1995; BALDO et al., 2002; NAMBA; BALDO, 2004; CRAVO; BALDO, 2008). Ao adaptarmos estes métodos para serem utilizados com animais artificiais, podemos detectar semelhanças no modo pelo qual animais artificiais e biológicos processam a informação sensorial e assim termos uma justificativa para utilizar as redes neurais a fim de tentar entender como o sistema nervoso funciona. Os experimentos com tempo de reação da seção Tempo de reação e vida artificial, a partir da página 87, por exemplo, são inteiramente baseados em experimentos psicofísicos clássicos que vêm sendo realizados com seres humanos e animais há décadas. Além disso, os resultados de simulações de vida artificial podem ser usados para entender ou gerar experimentos com seres humanos ou ainda prever os seus resultados, como uma forma de testar estes modelos. Esta abordagem nos dá uma ligação concreta entre simulações computacionais e a neurociência cognitiva, que procuramos explorar em nossos experimentos, conforme descritos a seguir. 


\section{OBJETIVOS}

\subsection{Objetivos gerais}

No presente trabalho, desenvolvemos simulações de vida artificial a fim de estudar a atenção seletiva, tomada de decisão em sequências binárias e tempo de reação ao aparecimento de um alvo precedido por pista. Nosso objetivo era determinar quais características do ambiente e das redes neurais levam à evolução de animais com comportamentos análogos àqueles associados a um dado processo cognitivo e assim obtermos um modelo matemático com base evolutiva.

\subsection{Objetivos especificos}

1. Desenvolver simulações de vida artificial baseadas em métodos psicofísicos, tradicionalmente utilizados em experimentos com animais biológicos, inclusive seres humanos; por exemplo, medidas de tempo de reação simples ao aparecimento abrupto de um alvo, medidas de detectabilidade (d'). Desta forma, torna-se possível determinar se os animais artificiais desenvolveram mecanismos cognitivos semelhantes aos dos animais biológicos.

2. Caso as redes neurais resultantes do processo evolutivo exibissem características cognitivas semelhante às encontradas em animais biológicos, usar os resultados obtidos no entendimento e previsão de resultados empíricos.

3. Testar tais previsões em seres humanos por meio de experimentos psicofísicos. 


\section{MÉTODOS}

Daremos, a seguir, uma descrição geral dos métodos utilizados em nossos experimentos.

\subsection{Redes Neurais}

Em simulações de vida artificial, o sistema nervoso é geralmente modelado utilizando redes neurais artificiais, que são máquinas projetadas para modelar o modo como o sistema nervoso funciona. Normalmente elas são implementadas utilizandose simulações em computador ou componentes eletrônicos. Em neurociências, as redes neurais artificiais são utilizadas como modelos teóricos das redes de neurônios que compõem o sistema nervoso.

As redes neurais são formadas por unidades de processamento simples, chamadas de nós, inspiradas nas células nervosas. Nas redes neurais, assim como no sistema nervoso, a informação é processada de forma maciçamente paralela, o que representa uma diferença importante entre elas e os computadores digitais tradicionais, os quais são programados para processar a informação de forma serial ou usando apenas algumas poucas linhas paralelas de execução.

\subsubsection{Perceptron}

O principal modelo de nó utilizado neste trabalho é o perceptron, que possui três elementos básicos (HAYKIN, 1998; TRAPPENBERG, 2002):

1. Um conjunto de sinapses, cada qual caracterizada por um peso (força). Na rede neural, o conhecimento é armazenado estabelecendo-se sinapses entre os nós com pesos variados. O aprendizado é definido como a modificação destes pesos sinápticos ao longo do tempo, usando direta ou indiretamente algum meio de realimentação (feedback), e os algoritmos de modificação dos pesos sinápticos são chamados de algoritmos de aprendizado.

2. Um somador, para somar os sinais de entrada, ponderados pelas respectivas sinapses. Eles incorporam a superposição de potenciais pós-sinápticos indivi- 
duais que ocorre em neurônios. A saída do somador é chamada de campo local induzido ou potencial de ativação.

3. Uma função de ativação, para restringir a amplitude da saída de um nó. Ela tem como parâmetro o campo local induzido do nó e como saída ela dá a taxa de disparo de potenciais de ação do nó. O perceptron não modela potenciais de ação individuais, somente a taxa de disparo.

Os nós podem também possuir um nível basal de ativação, chamado de viés. $\mathrm{O}$ viés é somado à saída do somador e pode aumentar ou diminuir o campo local induzido do neurônio, dependendo se ele é positivo ou negativo, respectivamente.

Neste trabalho, usamos a função de ativação $f(x)=\tanh (5 x)$, uma função sigmoide (Figura 4). Esta e outras funções sigmoides são bastante usadas como funções de ativação porque seu formato modela a taxa de disparo de um neurônio: quando o nível de ativação está abaixo do limiar, a taxa de disparo do neurônio é mínima; quando o nível de ativação ultrapassa o limiar, há um intervalo em que quanto maior é o nível de ativação, maior é a taxa de disparo do neurônio, até que o neurônio atinja a sua taxa de disparo máxima. Também usamos neste trabalho nós lineares, cuja função de ativação é $\mathrm{f}(\mathrm{x})=\mathrm{x}$, modelando receptores que não disparam potenciais de ação, como os fotorreceptores da retina. Estes nós foram utilizados somente na camada de entrada das redes neurais.

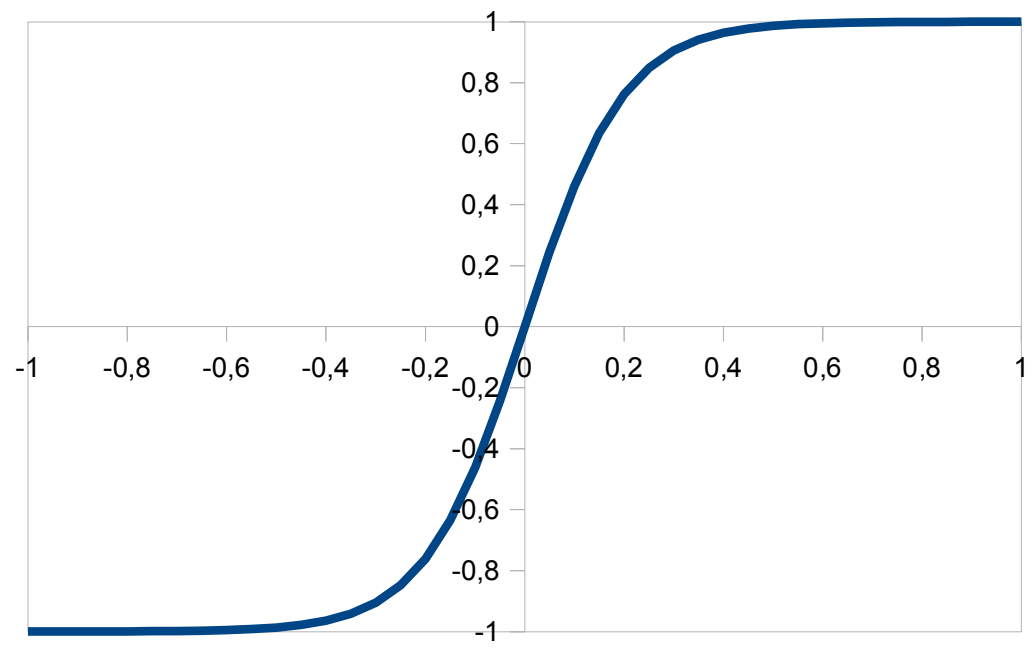

Figura 4 - Gráfico da função sigmoide $f(x)=\tanh (5 x)$. 


\subsubsection{Modelo integra-e-dispara}

A saída de um perceptron corresponde à taxa de disparo do neurônio que ele modela. Não é possível determinar o tempo de cada potencial de ação e não se pode acompanhar a somação temporal entre os estímulos. Nas simulações em que esta dinâmica temporal é importante, é necessário usar outros modelos de neurônio.

Um modelo simples que preenche esta função é o modelo integra-e-dispara. Ele modela cada neurônio pelo seu potencial de membrana (V), que evolui de acordo com a equação:

$$
V(t+1)=V_{\text {repouso }}+\left(V(t)-V_{\text {repouso }}\right) e^{\frac{-1}{\tau_{m}}}+I(t)
$$

onde $\mathrm{V}_{\text {repouso }}$ é o potencial de repouso do neurônio, $\mathrm{T}_{\mathrm{m}}$ é a constante de tempo da membrana, um número real maior do que zero, e I(t) é a entrada do neurônio no instante $t$, que engloba o viés, correntes externas e sinápticas, e é constante durante o intervalo de tempo considerado. Uma entrada proveniente de uma sinapse tem intensidade igual ao peso sináptico quando o neurônio pré-sináptico dispara um potencial de ação.

Quando o potencial da membrana atinge um limiar $\left(\mathrm{V}_{\text {limiar }}\right)$, considera-se que ocorreu um potencial de ação, sem que o mesmo tenha seu formato modelado, e o potencial da membrana é imediatamente restaurado a um valor $\mathrm{V}_{\text {restaurar }}$.

Em nossas simulações, usamos sempre os seguintes parâmetros:

$$
\mathrm{V}_{\text {limiar }}=\mathrm{V}_{\text {restaurar }}=-65 \mathrm{mV} ; \mathrm{V}_{\text {limiar }}=-40 \mathrm{mV} ; \tau_{\mathrm{m}}=10 \mathrm{~ms} \text {. }
$$

\subsubsection{Aprendizado hebbiano}

Em simulações de vida artificial, os pesos sinápticos de uma rede neural podem permanecer constantes durante toda a vida do animal e, neste caso, ele não é capaz de aprender, ou eles podem ser ajustados por algoritmos de aprendizado. $\mathrm{O}$ aprendizado ocorre com o tempo através de um processo interativo de ajustes aplicados aos pesos sinápticos e vieses das redes neurais como resultado da estimulação pelo ambiente (feedback).

Os algoritmos de aprendizado para redes neurais não precisam ser fiéis à biologia, mas aceitar tais restrições é importante para encontrar soluções biologicamente 
relevantes. Os modelos de aprendizado de inspiração biológica devem possuir as características a seguir (HAYKIN, 1998; TRAPPENBERG, 2002):

1. Não-supervisionado: o ambiente externo não fornece nenhum sinal de aprendizado a um neurônio específico quando um erro ocorre. A regra de aprendizado é uma função somente do histórico de disparo dos nós pré- e pós-sinápticos. Por exemplo, não existe um "professor" capaz de fornecer correções exatas de erro para as saídas da rede.

2. Local: cada peso sináptico se modifica em função dos nós associados àquela sinapse. Em organismos biológicos, não existem redes que permitem a passagem de mensagens entre múltiplas camadas de neurônio.

3. Online: a regra de aprendizado não requer o armazenamento de padrões de disparo ou de parâmetros da rede.

Um algoritmo de aprendizado que possui as características acima é o aprendizado hebbiano. Ele foi primeiramente proposto por Donald O. Hebb em 1949 (HEBB, 1949). É o mais antigo dos algoritmos de aprendizado e pode ser descrito em duas partes da seguinte forma:

1. Aumente a força da sinapse se um disparo pré-sináptico está pareado com um disparo pós-sináptico, ou seja, se os disparos dos nós de ambos os lados de uma sinapse estão temporalmente correlacionados.

2. Diminua a força da sinapse se os disparos pré-sináptico e pós-sinápticos não ocorrem em sincronia.

O algoritmo de aprendizado hebbiano, além de ser biologicamente inspirado, é usado em modelos de aprendizado associativo, como o condicionamento clássico. Um exemplo relacionado ao trabalho de Pavlov é dado a seguir.

A presença de comida à frente de um cão provoca a ativação supralimiar de um neurônio relacionado à salivação, fazendo com que o animal salive mais. Este estímulo (olfativo, visual ou gustativo) é chamado de estímulo não-condicionado, pois a resposta do neurônio a ele não muda com o aprendizado. Um outro estímulo, tal como um som, por si só não é inicialmente capaz de provocar uma resposta neste neurônio, pois a sinapse ativada pelo som não é suficientemente forte. Porém, quando o som e o estímulo incondicionado são apresentados simultaneamente, a forte ativação póssináptica provocada pelo estímulo incondicionado ocorre ao mesmo tempo em que o neurônio é estimulado pelo som. Com o aprendizado hebbiano, a sinapse ativada pelo som é fortalecida e, após algumas apresentações simultâneas dos dois estímulos, 
o som por si só é capaz de provocar o disparo do neurônio. O som é chamado de estímulo condicionado, pois a resposta do neurônio a ele foi modificada pelo aprendizado.

O algoritmo de aprendizado hebbiano tem sido bastante utilizado em experimentos de vida artificial (por exemplo, STEELS, 1993; FLOREANO; URZELAI, 2001) porque não requer supervisão externa ou sinais de aprendizado fornecidos pelo ambiente, além de poder ser aplicado a qualquer arquitetura de rede neural (FLOREANO; URZELAI, 2001).

\subsubsection{Arquiteturas de redes neurais}

A maneira pela qual os nós de uma rede neural estão conectados constitui a sua arquitetura. Em uma rede neural em camadas, os neurônios estão organizados em forma de camada.

Podemos identificar três classes de arquitetura de rede:

1. Redes alimentadas adiante (feedforward) com camada única, que são compostas por uma camada de entrada que se projeta sobre uma camada de saída.

2. Redes alimentadas adiante com múltiplas camadas, que se distinguem pela presença de uma ou mais camadas ocultas, que intervêm entre a entrada e a saída (por exemplo, veja a Figura 7 na página 49).

3. Redes recorrentes, que se distinguem de uma rede alimentada adiante por terem pelo menos um laço de realimentação (por exemplo, veja a Figura 31 na página 88$)$.

\subsection{Algoritmos genéticos}

Uma das vantagens da utilização de vida artificial para estudar fenômenos biológicos é que se torna possível observar a evolução de populações. A evolução em experimentos de vida artificial é implementada utilizando-se algoritmos genéticos, criados por John Holland nos anos 1970 (MITCHELL, 1998). Os algoritmos genéticos são algoritmos de otimização inspirados na Teoria da Evolução de Darwin (WHITLEY, 1994; MITCHELL, 1998), nos quais os problemas são resolvidos por um processo evolucionário que resulta em uma melhor (mais adaptada) solução (sobrevivente) - em outras palavras, a solução é evoluída. 
A cada corrida, o algoritmo começa com um ou mais conjuntos de soluções, representadas por "cromossomos", normalmente obtidos aleatoriamente. Cada solução é normalmente representada por um cromossomo, ou seja, os indivíduos são haplóides. Os cromossomos são vetores de genes, que por sua vez são geralmente números pertencentes a algum conjunto. $\mathrm{O}$ modo como as soluções são codificadas em forma de cromossomo é fundamental para habilidade de um sistema em evoluir. Um conjunto de soluções é chamado de população.

A cada indivíduo é atribuído um valor adaptativo (ou fitness), uma medida do seu desempenho ou grau de adaptação. Este é o valor que o algoritmo genético busca maximizar. Em experimentos de vida artificial, o valor adaptativo resulta da interação do animal artificial com o ambiente - por exemplo, aumenta com a quantidade de alimento ingerido - de modo que o algoritmo genético tende a tornar uma população cada vez mais adaptada ao seu ambiente.

Os descendentes dos indivíduos iniciais são obtidos pela aplicação dos três operadores genéticos abaixo:

1. Seleção: algoritmo de seleção dos organismos que irão se reproduzir. A probabilidade de um indivíduo ser selecionado para reprodução é uma função do valor adaptativo. Quanto maior é o valor adaptativo de um indivíduo, maior é a probabilidade de ele se reproduzir. Nos nossos experimentos, usamos um algoritmo de "seleção por torneio": é escolhido aleatoriamente um par de cromossomos e aquele com o maior valor adaptativo se reproduzirá.

2. Mutação: consiste na modificação de um gene. Por exemplo, se o gene é um número real, o algoritmo de mutação pode adicionar um número escolhido aleatoriamente ao valor original. As mutações geralmente ocorrem com probabilidade baixa e são responsáveis pela introdução de variação na população. Sempre utilizamos uma taxa de mutação de $5 \%$ por gene nos nossos experimentos.

3. Recombinação (crossover): algoritmo que combina genes de dois indivíduos (o "pai" e a "mãe") para formar um novo indivíduo. É inspirado na recombinação biológica entre dois cromossomos que ocorre durante a formação de gametas. Nos nossos experimentos, cada novo cromossomo tem dois pais e cada gene tem igual probabilidade de vir de cada um dos pais.

Existem outras estratégias que podem ser utilizadas além dessas para a obtenção de novos indivíduos (por exemplo, inversão e duplicação de genes) mas a maior 
parte das aplicações usa apenas os três operadores acima (MITCHELL, 1998). Além dos novos indivíduos, também copiamos para a próxima geração o indivíduo com maior valor adaptativo de cada população, uma estratégia chamada de elitismo, que impede que o melhor cromossomo seja eliminado da população.

Na maioria de nossas simulações, várias populações de 20 a 30 indivíduos evoluem paralelamente e, periodicamente, os melhores indivíduos de cada população migram para uma outra população escolhida ao acaso, mantendo o número de indivíduos de cada população constante.

Após a geração de descendentes dos indivíduos iniciais, os passos de atribuição de valor adaptativo, seleção e reprodução são repetidos até que alguma condição seja satisfeita, por exemplo, o número máximo de populações foi atingido. Cada iteração do processo é chamada de geração.

O conjunto de todas as soluções candidatas de um problema de otimização é chamado de "espaço de busca", termo que implica a existência de uma noção de "distância" entre as soluções candidatas. Um algoritmo de busca é um método de escolha de soluções candidatas a serem testadas. Os algoritmos genéticos assumem que exista uma relação entre a qualidade das soluções e sua proximidade no espaço de busca e que soluções de boa qualidade de diferentes regiões do espaço de busca podem ser combinadas para produzir, ocasionalmente, soluções candidatas de boa qualidade.

Se o cromossomo é um vetor de números reais de dimensão $n$, o espaço de busca pode ser representado por um gráfico de dimensão $n+1$, onde cada possível cromossomo é um ponto em $\mathrm{n}$ dimensões e o valor adaptativo é representado no eixo $\mathrm{n}+1$. Este tipo de gráfico é chamado de paisagem adaptativa. Uma paisagem adaptativa representa todos os possíveis genótipos com seus valores adaptativos. Tais gráficos normalmente apresentam "picos" e "vales". A adaptação pode ser vista como o movimento de convergência em direção aos picos. Um pico não é necessariamente o ponto mais alto da paisagem, mas qualquer movimento que se afasta dele causa uma diminuição do valor adaptativo. Os picos são chamados de pontos de ótimo locais. $\mathrm{O}$ maior ponto de ótimo local da paisagem é chamado de ponto de ótimo global.

Algumas vezes, o algoritmo genético, assim como outros métodos de otimização, pode ficar "preso" em um ponto de ótimo local, ou seja, toda a população está concentrada ao redor de um ponto de ótimo local e não há como avançar em direção ao ponto de ótimo global. Isso ocorre porque, ao redor de um ponto de ótimo local, 
os indivíduos têm um menor valor adaptativo e, portanto, menor probabilidade de se reproduzir. Pode não ser possível atravessar um vale que separa dois picos na paisagem adaptativa. $\mathrm{O}$ fenômeno em que o espaço de busca conduz a busca em direção a um ponto de ótimo local que não o ponto de ótimo global é chamado de engano (deception) (WHITLEY, 1991).

\subsubsection{Evolução de redes neurais artificiais}

É possível utilizar algoritmos genéticos para determinar os parâmetros de uma rede neural: os pesos sinápticos, a arquitetura e as regras de aprendizado. Assim, em simulações de vida artificial, o sistema nervoso dos animais é capaz de evoluir.

O cromossomo pode codificar todos os parâmetros de uma rede neural ou apenas o valor inicial dos parâmetros e/ ou outros parâmetros que afetam o aprendizado. No primeiro caso, o conhecimento armazenado na rede neural é inato, isto é, não há aprendizado durante o período de determinação do valor adaptativo. $O$ próprio algoritmo genético pode ser visto como um algoritmo de aprendizado para treinar redes neurais (NOLFI; PARISI, 2002). No segundo caso, as redes neurais se modificam através das gerações (aprendizado filogenético) e durante o período de tempo no qual o valor adaptativo dos indivíduos é calculado (aprendizado ontogenético). A evolução e o aprendizado são duas formas de adaptação que ocorrem em diferentes escalas de tempo. A evolução captura características do ambiente que são constantes ao longo de várias gerações enquanto que o aprendizado permite que o sistema nervoso se adapte a condições variáveis durante a vida do animal (NOLFI; FLOREANO, 1999). As duas formas de adaptação podem interagir de forma mutuamente benéfica (HINTON; NOWLAN, 1987; NOLFI; PARISI; ELMAN, 1994; NOLFI, 2002).

Para realizar a evolução de redes neurais, é necessário encontrar uma maneira de codificar a rede neural em um cromossomo de maneira a permitir o uso de operadores genéticos (seleção, mutação, recombinação etc). Nos esquemas de codificação direta, existe uma correspondência biunívoca entre os genes e as características fenotípicas da rede neural, sendo este esquema biologicamente implausível. Não é provável que todas as características do cérebro possam ser especificadas pelo código genético, pois o número de genes estimado no genoma humano (de 30 a 40 mil) não é suficiente para especificar todos os detalhes das redes neurais do sistema nervoso (TRAPPENBERG, 2002). Além disso, neste esquema, o comprimento do cromossomo 
aumenta com o grau de complexidade da rede, fazendo com que o tamanho do espaço de busca aumente também. Um outro problema é a impossibilidade de codificar estruturas repetidas de maneira compacta. Nos esquemas de codificação indireta, o cromossomo codifica as instruções de crescimento da rede.

Nos nossos experimentos, usamos somente os esquemas de codificação direta, por causa da simplicidade do algoritmo. Cada gene correspondia a um peso neural, viés ou parâmetro de aprendizado hebbiano.

\subsection{Experimentos psicofísicos com seres humanos}

Os experimentos foram realizados em uma sala com atenuação sonora e luz ambiente diminuída. Cada participante se sentava à frente a um monitor CRT de 19". As rotinas computacionais foram elaboradas por meio de programas desenvolvidos pela autora, na linguagem de programação Python usando a biblioteca gráfica pyglet ou usando o software E-Prime versão 1.2.

Os sujeitos de nossos experimentos eram alunos voluntários de graduação ou pós-graduação da USP, na faixa etária de 18 a 30 anos. Eles possuíam acuidade visual normal ou corrigida e condições normais de saúde. Eles eram informados sobre o tipo de experimento e respectivos procedimentos, mas não eram informados antecipadamente sobre os objetivos específicos de cada experimento. Eles preenchem ainda um de Termo de Consentimento Livre e Esclarecido.

Estímulos visuais eram exibidos na tela do computador e em seguida os participantes deviam emitir uma resposta a estes estímulos usando um teclado.

\subsection{Representação gráfica}

As barras de erro nos gráficos deste trabalho, a menos que seja indicado o contrário, correspondem ao erro padrão (EP) da média, calculado por:

$$
E P=\frac{D P}{\sqrt{n}}
$$

onde DP é o desvio padrão amostral e $n$ é o número de elementos da amostra. Ele é uma estimativa do desvio padrão das médias de todas as possíveis amostras de tamanho $n$ retiradas da população em estudo. Percebe-se facilmente que o erro padrão é menor quanto maior é o tamanho da amostra. 


\section{TOMADA DE DECISÃO EM ESCOLHAS BINÁRIAS REPETIDAS}

\subsection{Introdução}

Conforme vimos na seção sobre tomada de decisão da introdução geral, ao tentar explicar por que os seres humanos adotam uma estratégia sub-ótima no experimento de escolha binária repetida, chegou-se à ideia de que o pareamento de probabilidades deve ter sido uma estratégia adequada para sobreviver no ambiente em que os seres humanos evoluíram, mas não no ambiente artificial de um laboratório. Uma técnica poderosa para testar teorias ecológicas e evolutivas, a qual concebe características cognitivas como estratégias boas para sobreviver em um dado ambiente, é vida artificial.

Nesta série de experimentos, nós buscamos fazer a união entre a visão ecológica e evolutiva com a explicação de busca de padrões. O primeiro experimento é uma reprodução do experimento clássico de escolha binária repetida, usando como sujeitos alunos de graduação. Já no segundo experimento, nós propusemos um modelo matemático na forma de uma simulação de vida artificial que mostra como ser evolutivamente selecionado por aprender um padrão leva ao pareamento de probabilidades e como não ter sucesso em aprendê-lo leva à maximização. Os experimentos seguintes desta seção são baseados na teoria das cadeias de Markov, apresentadas na seção 1.2.1.

\subsection{Experimento 1}

Neste experimento, reproduzimos os resultados clássicos de escolha binária repetida obtidos em experimentos com seres humanos com probabilidades $70 \%$ e $30 \%$ de o estímulo aparecer de um lado ou de outro da tela. Dezoito entre 90 sujeitos receberam a informação de que estímulo aparecia aleatoriamente com maior probabilidade de de um lado do que do outro sem obedecer a um padrão determinístico. 


\subsubsection{Métodos}

Submeteram-se ao experimento 90 estudantes de graduação do curso de odontologia, dos quais 74 eram mulheres. Cada sujeito escolhia entre duas opções (lado esquerdo ou lado direito da tela do computador) em uma sequência de 300 apresentações. Após a escolha, se a recompensa estivesse no lado escolhido, o voluntário recebia uma quantidade fixa de pontos. A probabilidade de o estímulo aparecer à direita da tela era mantida constante ao longo do experimento: $70 \%$ para metade dos participantes e 30\% para a outra metade. Enquanto 72 voluntários não receberam qualquer informação prévia sobre a estrutura das sequências, 18 foram informados que não havia um padrão fixo e o resultado de cada apresentação era sorteado aleatoriamente com maior probabilidade de sair um lado do que o outro. Os voluntários também eram informados de que todos os quadrados eram idênticos e estavam sempre nas mesmas posições; não havia nada na tela que pudesse dar uma pista ao voluntário sobre a posição da bola.

As apresentações se iniciavam com o surgimento de dois quadrados cinzas, um de cada lado da tela. O sujeito deveria pressionar a tecla A se ele acreditasse que uma bola estava "escondida" atrás do quadrado da esquerda e a tecla L se ele acreditasse que a bola estava "escondida" atrás do quadrado da direita. Imediatamente após a resposta, a bola aparecia na tela juntamente com uma mensagem, "Acertou!" ou "Errou!", dependendo, respectivamente, se o sujeito acertou ou não a posição da bola. A informação permanecia na tela por 500 ms, terminando a apresentação (Figura 5). As apresentações estavam divididas em 5 blocos de 60 apresentações.

Ao final do experimento, os voluntários preenchiam um questionário com a seguinte pergunta: “Qual estratégia você usou para adivinhar de que lado estaria a bola?" A partir dos resultados, os voluntários foram separados em três categorias estratégicas: suprapareadores (escolheram a alternativa mais frequente em mais de $80 \%$

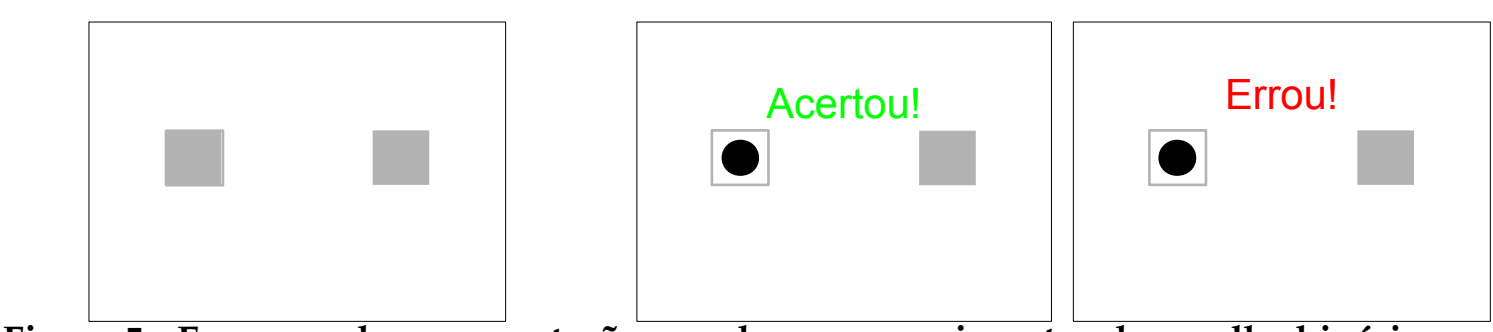

Figura 5 - Esquema das apresentações usadas em experimentos de escolha binária repetida com seres humanos. 
das apresentações); pareadores (escolheram a alternativa mais frequente entre $60 \%$ e $80 \%$ das apresentações); subpareadores (escolheram a alternativa mais frequente em menos de $60 \%$ das apresentações). Os resultados numéricos foram analisados estatisticamente com o teste qui-quadrado. 


\subsubsection{Resultados e Discussão Parcial}

Não observamos diferença estatística entre os gêneros $(p=0,714)$. A informação prévia quanto à estrutura da sequência produziu uma diferença estatisticamente significativa ( $\mathrm{p}=0,024): 50 \%$ dos voluntários que foram informados previamente sobre a aleatoriedade da sequência adotaram uma estratégia suprapareadora (que tende à maximização), enquanto apenas $20 \%$ do grupo não informado adotou a mesma estra-

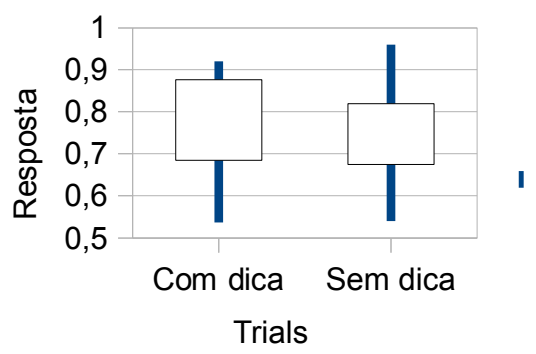

Figura 5 - Diferença na resposta dos voluntários que receberam a dica ("esta sequência é aleatória") e os que não receberam a dica.

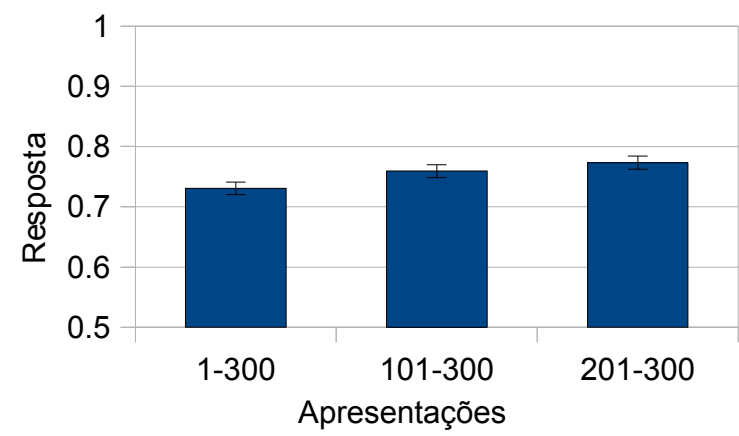

Todos os voluntários

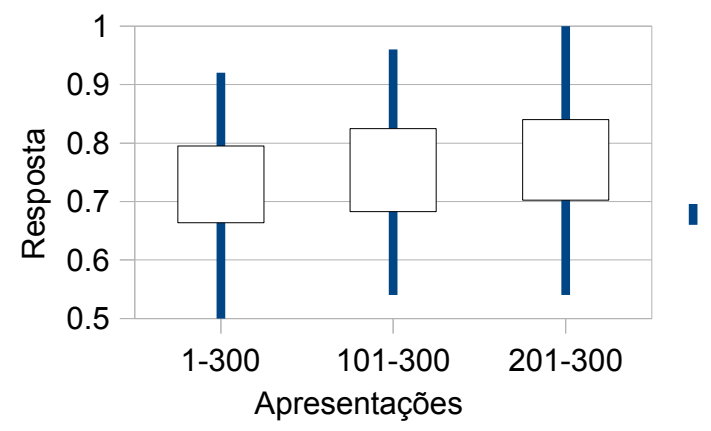

Todos os voluntários

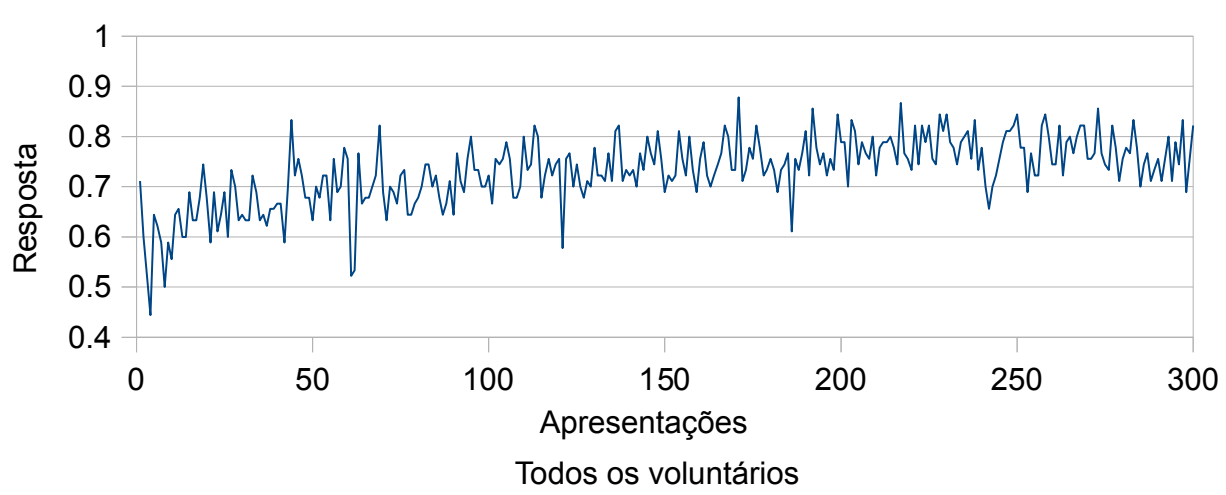

Figura 6 - Respostas dos sujeitos do experimento 1, com seres humanos. No primeiro gráfico, é mostrada a média das respostas médias dos sujeitos. No segundo gráfico, o mínimo, primeiro quartil, terceiro quartil e o máximo das respostas médias dos sujeitos. No terceiro gráfico, a média da resposta dos sujeitos para cada apresentação. Para calcular a resposta média, considerou-se que o lado mais frequente tem valor 1 e o lado menos frequente tem valor 0 . 
tégia (Figura 5). A análise da evolução na estratégia adotada por todos os voluntários revelou, ao longo de 3 trechos temporais sucessivos, um aumento na frequência de escolha da alternativa mais provável: $67,4 \%, 74,5 \%$ e 77,3\% ( $\mathrm{p}<0,001)$, o que sugere uma convergência ao limite superior da faixa pareadora (Figura 6).

Os nossos resultados replicam aqueles reportados na literatura; por exemplo, notamos que mesmo ao serem informados de que não há um padrão na sequência, $50 \%$ dos sujeitos adotaram uma estratégia pareadora ou subpareadora. Além disso, os dados aqui coletados (cadeias de Markov de ordem zero; veja seção 1.2.1 na página 18) são a base de referência para experimentos posteriores, onde foram empregadas sequências binárias geradas por cadeias de Markov de ordens superiores.

\subsection{Experimento 2}

Com este experimento de vida artificial, nós criamos um modelo computacional que mostra como o comportamento do pareamento de probabilidades pode surgir da adaptação evolutiva a um ambiente regular, cujo padrão pode ser aprendido.

\subsubsection{Métodos}

Em nossas simulações, animais artificiais tinham que realizar uma tarefa, chamada de tarefa de pareamento de padrões. Ela consistia em prever repetidamente o próximo elemento de uma sequência binária formada por um padrão que se repetia. Um exemplo de padrão era 101, levando à sequência 101101101... Durante suas vidas, a cada unidade de tempo, os animais tinham que escolher entre 0 e 1 . Quando suas escolhas previam corretamente o próximo elemento da sequência, eles ganhavam pontos de valor adaptativo. $\mathrm{O}$ tamanho do padrão que se repetia, e portanto a sua dificuldade de ser aprendido, variava em diferentes simulações entre 3, 9, 27, 81, 243 ou 729 dígitos (seis tamanhos diferentes). As frequências dos dígitos 0 e 1 nos padrões que se repetiam eram sempre 1/3 e 2/3 respectivamente, e os padrões eram repetidos até que o comprimento total da sequência fosse 2916. Nós testamos doze padrões aleatoriamente gerados para cada comprimento dado e cada um destes padrões era apresentado a todos os animais de uma simulação, totalizando $72(6 \times 12)$ padrões e simulações. Há, no entanto, somente três possíveis padrões de comprimento 3 (011, 101 e 110) e as sequências formadas por qualquer um deles são basicamente as mes- 

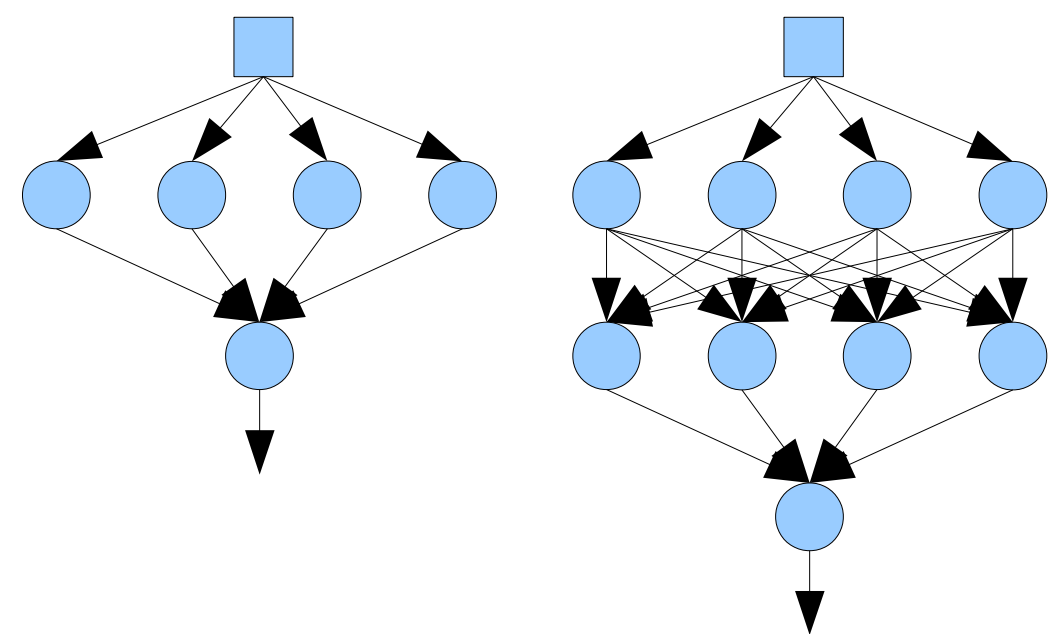

Figura 7 - Arquiteturas de redes utilizadas no experimento computacional de pareamento de probabilidades.

mas exceto por começarem de um ponto diferente. Ainda assim, realizamos doze simulações com padrões de comprimento 3, repetindo cada um dos três possíveis padrões quatro vezes.

Os animais tinham redes neurais alimentadas adiante, da arquitetura perceptron de múltiplas camadas, com camadas totalmente conectadas, um nó linear de entrada, uma ou duas camadas de quatro nós ocultos e um nó de saída (Figura 7). Esta variação no número de nós ocultos se refletia em uma maior ou menor capacidade para aprender padrões. Quando o nó de saída era ativado acima de um limiar e a sua saída era maior do que zero, o animal tinha previsto que o próximo número seria 1. Caso contrário, a resposta do animal era 0 . O nó de entrada capturava feedback do ambiente para a rede neural. $\mathrm{O}$ feedback era +5 se o animal tinha adivinhado corretamente o dígito anterior e -5 caso contrário. Os pesos sinápticos podiam mudar no tempo de acordo com as regras de aprendizado hebbiano e anti-hebbiano - quando dois nós disparam ao mesmo tempo, o peso da sinapse entre eles aumenta (regra hebbiana) ou diminui (regra anti-hebbiana). Através desta regra simples, a rede neural podia aprender com o feedback que ela recebia a cada unidade de tempo. Isso permitia à rede ter diferentes respostas ao mesmo estímulo dependendo do estímulo que veio anteriormente, o que é necessário para que a rede possa repetir os padrões corretamente. Os pesos sinápticos iniciais e um parâmetro de aprendizado eram números reais entre -5 e +5 determinados geneticamente. Os genomas dos animais evoluíam com mutações e crossover por meio de um algoritmo genético. Na geração zero, cem cromossomos foram gerados aleatoriamente com distribuição uniforme para cada 
gene. Estes cromossomos foram distribuídos em cinco populações de vinte indivíduos. Redes neurais foram construídas baseadas nos cromossomos e os animais faziam a tarefa de pareamento de padrões. O número de respostas corretas era o valor adaptativo do animal. A seleção no algoritmo genético era por torneio de duplas, a taxa de mutação era 5\% e a mutação consistia em adicionar ao gene um número aleatório com distribuição uniforme entre $-0,01$ e $+0,01$. O número total de gerações era de 1000 com migração a cada 100 gerações.

Os animais da última geração de cada simulação realizavam uma tarefa adicional, que nós chamamos de tarefa da sequência aleatória. Ela era similar à tarefa anterior com as quais os animais evoluíram, exceto que a sequência de zeros e uns que os animais tinham que prever era completamente aleatória e sem memória com a mesma proporção entre zeros e uns da sequência anterior. A sequência não era mais formada de um padrão menor que se repetia. O desempenho dos animais nesta tarefa era comparado com o desempenho dos animais na tarefa anterior através do cálculo da acurácia na previsão (a proporção entre o número de previsões corretas e o número total de previsões) e da resposta média (ou previsão média). Uma resposta média próxima a 0,67 indicava que os animais fizeram pareamento de probabilidades; quando era próxima a 1 , indicava que eles maximizaram.

\subsubsection{Resultados e Discussão Parcial}

Os resultados estão mostrados nas figuras 8, 9, 10 e 11. As figuras 8 e 9 mostram a acurácia média dos animais da última geração do experimento e as figuras 10 e 11 mostram a resposta média destes animais. 


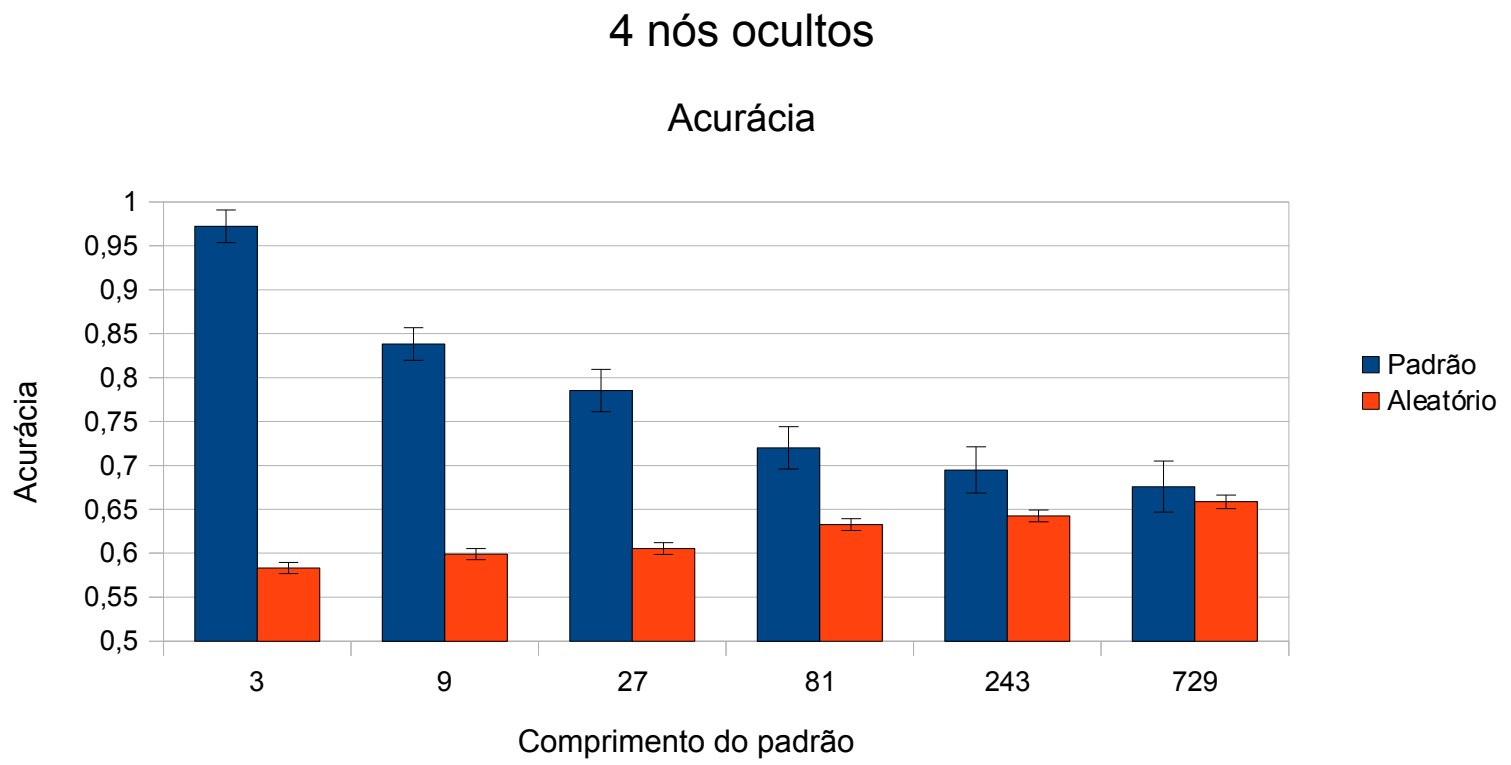

Figura 8 - Acurácia dos animais artificiais com 4 nós ocultos na última geração em função do comprimento do padrão usado na simulação, nas duas tarefas: pareamento de padrões ou sequência aleatória.

\section{8 nós ocultos}

Acurácia

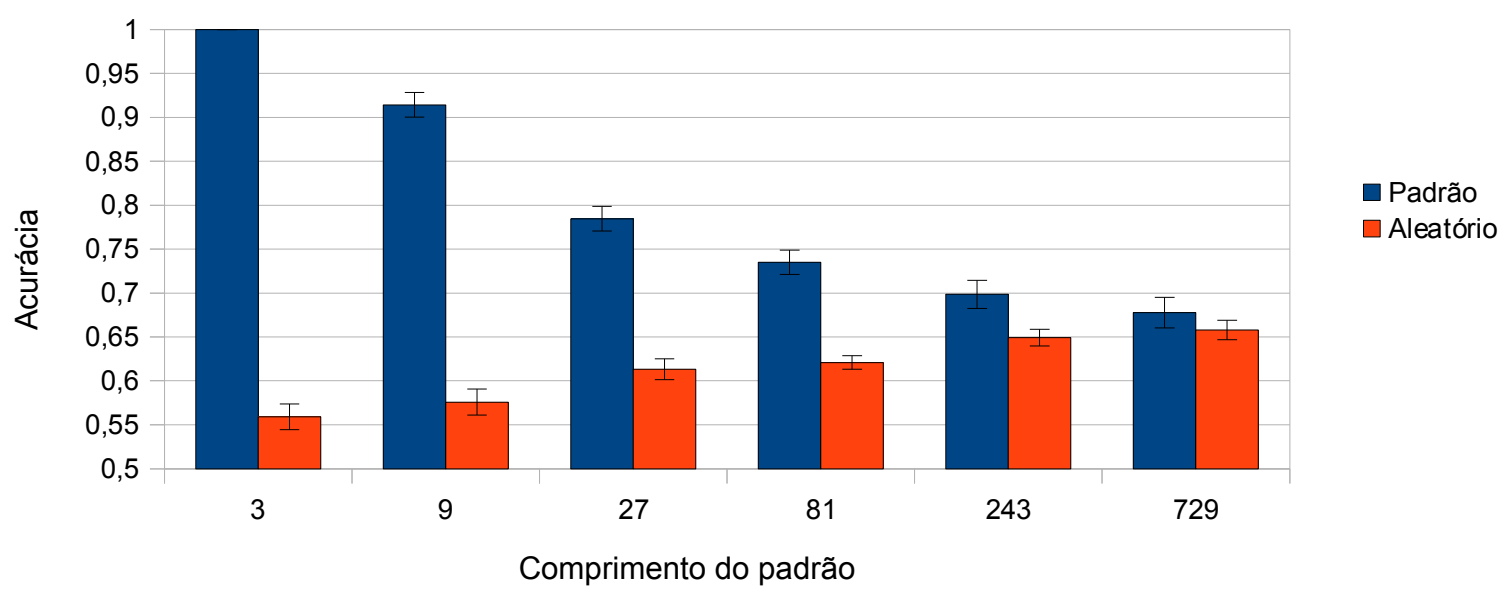

Figura 9 - Acurácia dos animais artificiais com 8 nós ocultos na última geração em função do comprimento do padrão usado na simulação, nas duas tarefas: pareamento de padrões ou sequência aleatória. 


\section{4 nós ocultos}

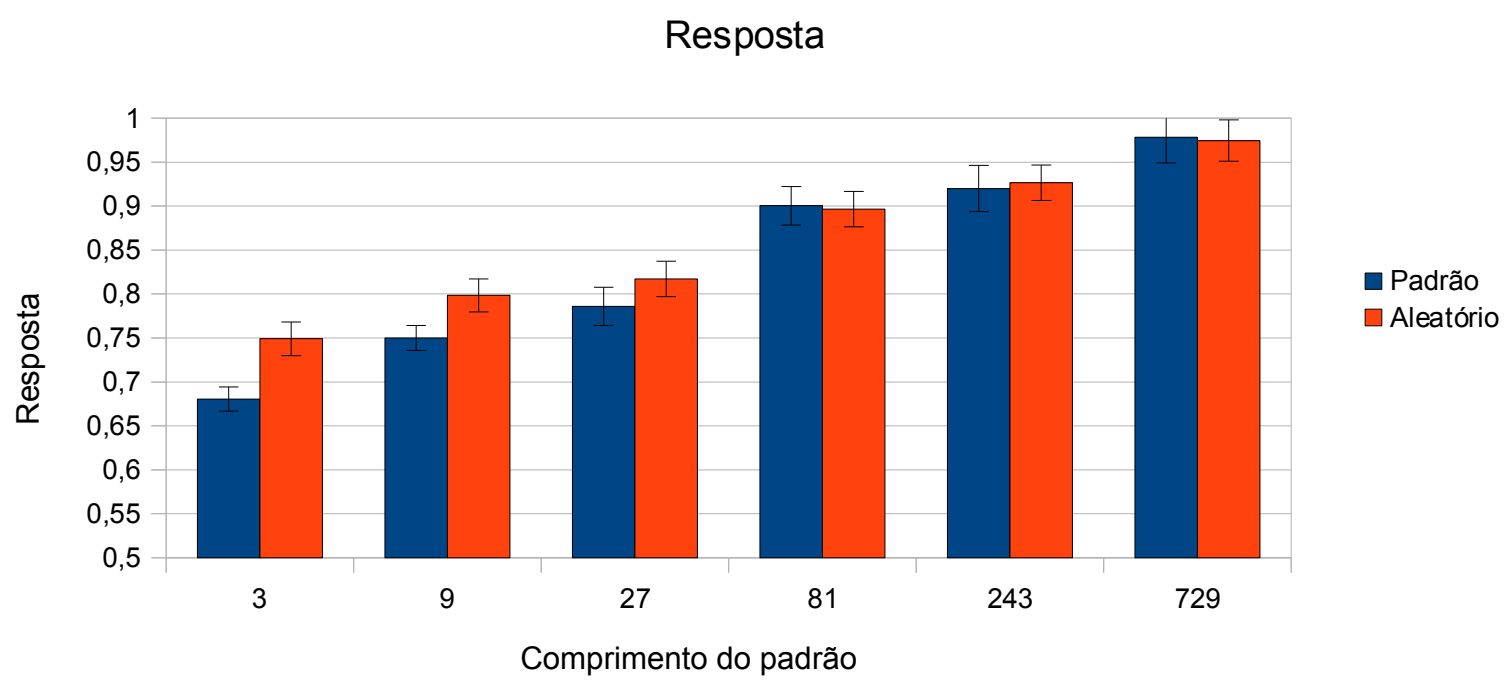

Figura 10 - Resposta média dos animais artificiais com 4 nós ocultos na última geração em função do comprimento do padrão usado na simulação, nas duas tarefas: pareamento de padrões ou sequência aleatória.

\section{8 nós ocultos}

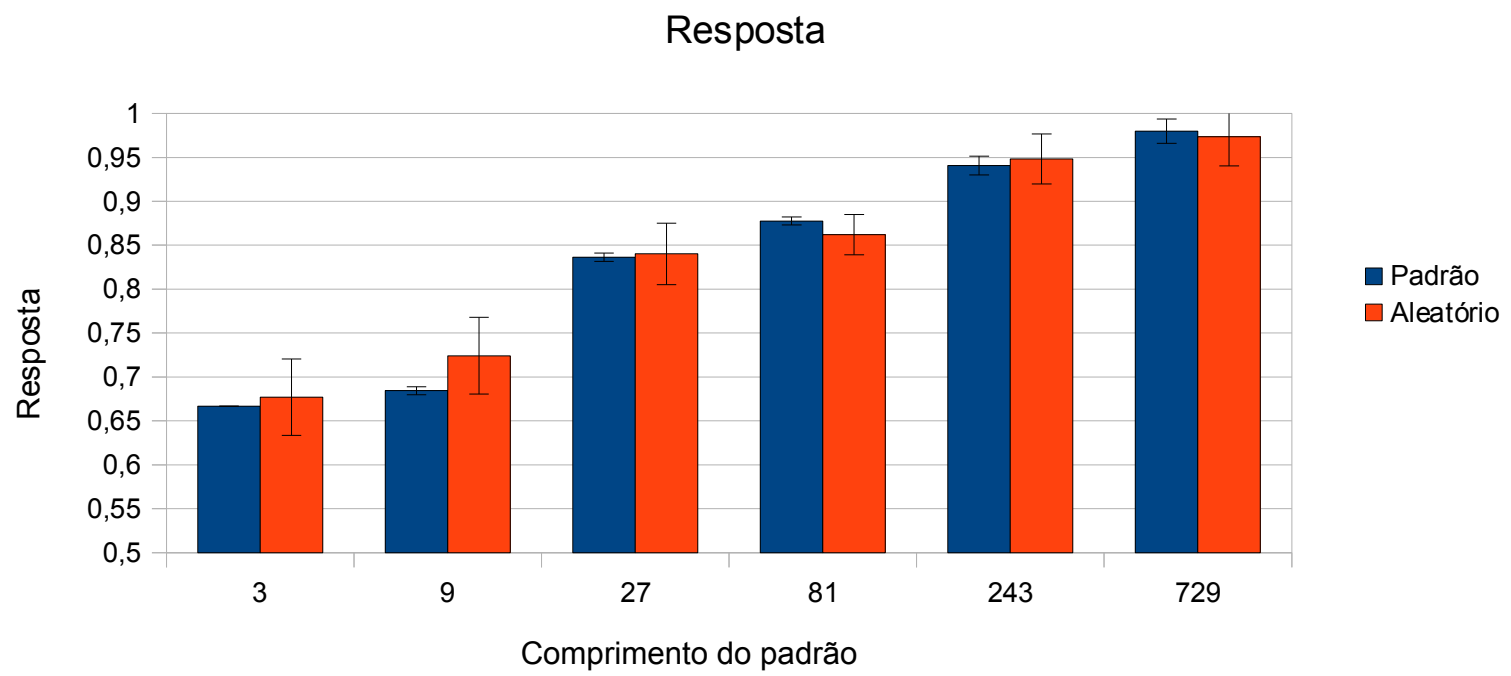

Figura 11 - Resposta média dos animais artificiais com 8 nós ocultos na última geração em função do comprimento do padrão usado na simulação, nas duas tarefas: pareamento de padrões ou sequência aleatória. 
Os animais dotados de mais nós ocultos e que evoluíram com sequências de entrada compostas de padrões repetitivos mais curtos, eram capazes de aprender um padrão repetitivo e atingir uma maior acurácia, chegando próximo a uma taxa de previsões corretas de 100\%. Mas quando os animais da última geração realizavam a tarefa adicional da sequência aleatória, a acurácia estava abaixo do valor ótimo de 67\% que eles poderiam ter atingido com a maximização e próxima do 56\% esperado para o pareamento de probabilidades. De fato, em ambas as tarefas eles previam 1 com frequência de cerca de $67 \%$, ou seja, a estratégia era sempre o pareamento de probabilidades.

No outro extremo, os animais dotados de menor número de nós ocultos, e que evoluíram com sequências de entrada compostas de padrões repetitivos mais longos, não eram capazes de aprender o padrão repetitivo e tinham que adotar uma estratégia próxima da maximização, atingindo uma acurácia um pouco acima de $67 \%$. Quando estes animais eram testados com uma sequência aleatória, a acurácia permanecia ao redor de $67 \%$, que é quase ótimo sob estas circunstâncias. Na verdade, dada a falta de capacidade neural para aprender padrões repetitivos longos, os animais que exibiam o comportamento mais adaptativo - e portanto eram selecionados ao longo de sucessivas gerações - eram aqueles que adotavam uma estratégia maximizadora, na qual o resultado 1 deve ser previsto com frequência próxima de $100 \%$. Conforme poderíamos esperar, a mesma estratégia ótima é adotada quando estes animais lidavam com uma sequência completamente aleatória. Em resumo, quanto melhor é o desempenho de um animal na tarefa de aprendizado de padrões, mais próximo do pareamento de probabilidades ele se mostra na tarefa da sequência aleatória. Já os animais que maximizam na tarefa de pareamento de padrões (por não serem capazes de aprendê-los) também maximizam na tarefa da sequência aleatória.

Os nossos resultados sugerem que os módulos cognitivos do sistema nervoso humano que buscam por padrões no ambiente têm sido cruciais na evolução humana. Quando um padrão é encontrado, previsões acuradas podem ser feitas e o desempenho melhora. Na tarefa de pareamento de padrões, um sujeito que descobre o padrão poderá sempre prever o próximo elemento da sequência corretamente - dizemos que o animal "quebrou o código" a ele apresentado pelo ambiente. Uma análise superficial deste comportamento irá gerar a conclusão de que o sujeito se comporta de acordo com uma estratégia de pareamento de probabilidades (o que de fato é verdade), mas com um desempenho que alcança níveis ótimos. Um sujeito que não é ca- 


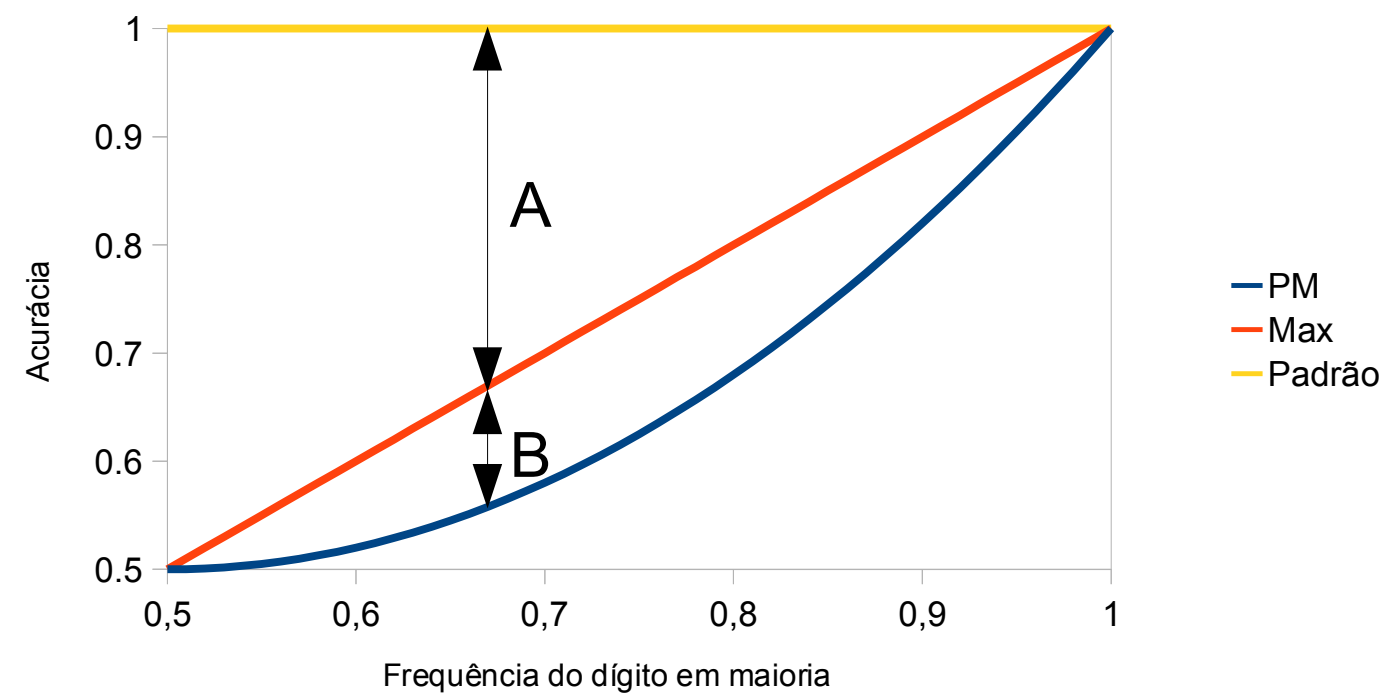

Figura 12 - Acurácia prevista no experimento de escolha binária repetida dependendo da frequência do dígito em maioria e da estratégia empregada: PM (pareamento de probabilidades sem decodificação de padrão), Max (maximização) and Padrão (decodificação de padrão). Para todas as frequências de dígitos, a diferença em acurácia entre a decodificação de padrão e a maximização (seta A) é maior que a diferença em acurácia entre a maximização e o pareamento de probabilidades sem decodificação de padrão (seta B).

paz de encontrar o padrão só pode maximizar, escolhendo o resultado mais frequente e prevendo o próximo elemento da sequência corretamente em dois terços das apresentações (no caso aqui discutido, um terço a menos do que o sujeito que foi capaz de encontrar o padrão).

$\mathrm{Na}$ tarefa de pareamento de padrões, a diferença teórica na acurácia entre decodificar o padrão (levando ao pareamento de probabilidades) e maximização é de um terço, três vezes maior do que a diferença entre o pareamento de probabilidades e a maximização na tarefa da sequência aleatória, que é só de um nono. Mais do que isso, a Figura 12 mostra que, em qualquer experimento de escolha binária repetida, para todas as frequências do dígito majoritário, a diferença em acurácia entre a decodificação de padrão e a maximização é maior que a diferença em acurácia entre a maximização e o pareamento de probabilidades sem decodificação de padrão. Este resultado demostra que buscar por padrões leva a ganhos maiores quando um padrão existe e a perdas relativamente pequenas quando um padrão não existe. Portanto, a tendência a buscar por padrões pode não ser adaptativa quando eles não existem, mas este é justamente o caso em que muito pouco pode ser previsto de qualquer modo, não importando qual estratégia é empregada. 
A decodificação de padrões pode ocorrer conscientemente ou não. Como alguns animais artificiais, os seres humanos adultos podem nunca decidir maximizar, a não ser que eles sejam explicitamente ensinados a fazer isso. A natureza intrínseca do pareamento de probabilidades pode ser ilustrada ao se observar que as pessoas fazem pareamento de probabilidades também quando elas executam tarefas comuns: determinar uma doença dados os seus sintomas (SHANKS; TUNNEY; MCCARTHY, 2002), classificar uma medida de altura como pertencente a um homem ou uma mulher (HEALY; KUBOVY, 1981), tomar a decisão apropriada em resposta a alarmes (BLISS; GILSON; DEATON, 1995), localizar estímulos áudio-visuais no espaço (WOZNY; BEIERHOLM; SHAMS, 2010). Tem-se comentado repetidamente que os seres humanos têm dificuldade em reconhecer a aleatoriedade e, como a falácia do jogador discutida na introdução desta seção ilustra, têm uma intuição incorreta dela (BARHILLEL; WAGENAAR, 1991; FALK; KONOLD, 1997).

Os seres humanos estão sempre tentando encontrar um padrão determinístico que eles possam aprender e usar para fazer previsões corretas o tempo todo. Wolford et al. (2000) fizeram um experimento com pacientes calosotomizados, que participaram de um experimento de busca binária repetida duas vezes, usando cada hemisfério cerebral isoladamente. Foi observado que os hemisférios esquerdos tendiam a fazer pareamento de probabilidades enquanto que os hemisférios direitos maximizavam. Os autores propuseram que o hemisfério esquerdo tem um módulo "interpretador", que tenta "extrair um sentido da informação que ele confronta", e é este módulo interpretador que busca por padrões em sequências, mesmo quando um padrão não existe. Miller e Valsangkar-Smyth (2005), no entanto, descobriram que quando os estímulos usados eram fotografias de faces humanas, o hemisfério direito pareava a frequência das ocorrências anteriores e o hemisfério esquerdo não. Portanto, é possível que a busca de padrões não esteja restrita a uma região neural específica, mas ao invés disso é um mecanismo difuso no córtex humano. Ele provavelmente afeta o comportamento humano toda vez que uma sequência de observações é realizada, portanto ele pode influenciar não só o experimento de escolha binária repetida e suas variações, mas também uma ampla gama de experimentos em tomada de decisão e outros ramos das ciências cognitivas, bem como as nossas vidas diárias. 


\subsection{Experimentos 3 e 4}

Nestes experimentos, avaliamos o comportamento de seres humanos em prever sequências geradas pela cadeia de Markov de ordem 1 cuja matriz de transição é dada pela Tabela 9 (experimento 3) e pela cadeia de Markov de ordem 2 cuja matriz de transição é dada pela Tabela 10 (experimento 4).

Tabela 9 - Cadeia de Markov de ordem 1 usada no experimento 3, com seres humanos.

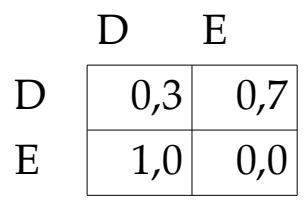

Tabela 10 - Cadeia de Markov de ordem 2 usada no experimento 4, com seres humanos.

\begin{tabular}{|c|c|c|}
\hline & & $E$ \\
\hline DD & 0,7 & 0,3 \\
\hline $\mathrm{DE}$ & 0,0 & 1,0 \\
\hline & 0,3 & 0,7 \\
\hline & 1,0 & 0,0 \\
\hline
\end{tabular}

A cadeia de ordem 1 foi escolhida por ter uma entropia de ordem 0 próxima a 1 $(0,98)$ e uma taxa de entropia de ordem 1 mais baixa $(0,52)$. Isso quer dizer que somente se os sujeitos entenderem o padrão de ordem 1 eles poderão prever o próximo elemento da sequência acima com desempenho melhor do que o que pode ser obtido por pura sorte. Um exemplo de sequência gerada por esta tabela é EDEDEDDEDEDEDDEDEDED.

A cadeia de ordem 2 foi escolhida por ter uma entropia de ordem 0 e uma taxa de entropia de ordem 1 iguais a 1 e uma taxa de entropia de ordem 2 mais baixa $(0,44)$. Isso quer dizer que os sujeitos só podem prever o próximo elemento da sequência acima com desempenho acima da sorte se eles entenderem o padrão de ordem 2. Um exemplo de sequência gerada por esta tabela é DEEDEEDEEDEEDEEDDDDDEEDEEDEEDEEDDDDDEE.

\subsubsection{Métodos}

O procedimento é semelhante ao do experimento 1, exceto que só havia dois blocos de 150 ou 250 apresentações cada (só um sujeito fez o experimento com dois 
blocos de 150 apresentações; os outros fizeram o experimento com dois blocos de 250 apresentações). Diminuímos o número de blocos, pois muitos voluntários achavam que a sequência mudava ou se reiniciava entre um bloco e outro. Os cinco voluntários que fizeram o experimento 3 e os três voluntários que fizeram o experimento 4 eram alunos de pós-graduação.

Para analisar a resposta dos voluntários no experimento 3, calculamos a probabilidade de o voluntário responder esquerda (E) dado que o resultado anterior foi direita (D) e a probabilidade de o voluntário responder direita (D) dado que o resultado anterior foi esquerda (E). Representaremos estas duas probabilidades por $\mathrm{p}\left(\mathrm{R}_{2}=\mathrm{E}\right.$ I $\left.X_{1}=\mathrm{D}\right)$ e $\mathrm{p}\left(\mathrm{R}_{2}=\mathrm{D} \mid \mathrm{X}_{1}=\mathrm{E}\right)$, respectivamente. Estas probabilidades foram calculadas somente para as 100 últimas apresentações do experimento. A probabilidade de a bola de fato aparecer à esquerda (E) dado que o resultado anterior foi direita (D) e a probabilidade de a bola de fato aparecer à direita $(\mathrm{D})$ dado que o resultado anterior foi esquerda (E) respectivamente serão representados por $p\left(X_{2}=E\right.$ । $\left.X_{1}=D\right)$ e $p\left(X_{2}=\right.$ D | $X_{1}=$ E) e têm os valores 0,7 e 1,0 segundo a Tabela 9.

Para analisar a resposta dos voluntários no experimento 4 , calculamos a probabilidade de o voluntário responder direita (D) dados os dois resultados anteriores. Representaremos estas quatro probabilidades por $\mathrm{p}\left(\mathrm{R}_{3}=\mathrm{D} \mid \mathrm{X}_{1}=\mathrm{D}, \mathrm{X}_{2}=\mathrm{D}\right), \mathrm{p}\left(\mathrm{R}_{3}=\mathrm{D}\right.$ | $\left.\mathrm{X}_{1}=\mathrm{D}, \mathrm{X}_{2}=\mathrm{E}\right), \mathrm{p}\left(\mathrm{R}_{3}=\mathrm{D} \mid \mathrm{X}_{1}=\mathrm{E}, \mathrm{X}_{2}=\mathrm{D}\right)$ e $\mathrm{p}\left(\mathrm{R}_{3}=\mathrm{D} \mid \mathrm{X}_{1}=\mathrm{E}, \mathrm{X}_{2}=\mathrm{N}\right)$. Estas probabilidades foram calculadas para cada sujeito somente para as 100 últimas apresentações do experimento. A probabilidade de a bola de fato aparecer à direita (D) dados que os dois resultado anteriores foram $\mathrm{DD}$, por exemplo, será representada por $\mathrm{p}\left(\mathrm{X}_{3}\right.$ $=\mathrm{E} \mid \mathrm{X}_{1}=\mathrm{D}, \mathrm{X}_{2}=\mathrm{D}$ ) e de forma análoga representaremos as probabilidades de a bola de fato aparecer à direita dados os outros possíveis resultados das duas apresentações anteriores. 


\subsubsection{Resultados e Discussão Parcial}

Os resultados do experimento 3 são mostrados na Tabela 11 e os resultados do experimento 4 são mostrados na Tabela 12.

Tabela 11 - Resultados do experimento 3, com uma cadeia de Markov de ordem 1 em seres humanos.

\begin{tabular}{l|r|r}
\hline Sujeito & $\mathbf{p}\left(\mathbf{R}_{\mathbf{2}}=\mathbf{E} \mid \mathbf{X}_{\mathbf{1}}=\mathbf{D}\right)$ & $\mathbf{p}\left(\mathbf{R}_{\mathbf{2}}=\mathbf{D} \mid \mathbf{X}_{\mathbf{1}}=\mathbf{E}\right)$ \\
\hline 1 & 0,77 & 0,75 \\
\hline 2 & 0,98 & 1,00 \\
\hline 3 & 0,49 & 0,79 \\
\hline 4 & 0,69 & 0,97 \\
\hline 5 & 0,84 & 0,97 \\
\hline Média & 0,78 & 0,92 \\
\hline
\end{tabular}

Tabela 12 - Resultados do experimento 4, com uma cadeia de Markov de ordem 2 em seres humanos.

\begin{tabular}{|c|c|c|c|c|}
\hline Sujeito & $\begin{array}{c}\mathrm{p}(\mathrm{R} 3=\mathrm{D} \\
\mathrm{X} 1=\mathrm{D}, \mathrm{X} 2=\mathrm{D})\end{array}$ & $\begin{array}{c}\mathrm{p}(\mathrm{R} 3=\mathrm{D} \\
\mathrm{X} 1=\mathrm{D}, \mathrm{X} 2=\mathrm{E})\end{array}$ & $\begin{array}{c}\mathrm{p}(\mathrm{R} 3=\mathrm{D} \\
\mathrm{X} 1=\mathrm{E}, \mathrm{X} 2=\mathrm{D})\end{array}$ & $\begin{array}{c}\mathrm{p}(\mathrm{R} 3=\mathrm{D} \\
\mathrm{X} 1=\mathrm{E}, \mathrm{X} 2=\mathrm{N})\end{array}$ \\
\hline 1 & 0,64 & 0,00 & 0,10 & 1,00 \\
\hline 2 & 0,65 & 0,13 & 0,65 & 0,87 \\
\hline 3 & 0,61 & 0,00 & 0,68 & 0,91 \\
\hline Média & 0,63 & 0,04 & 0,48 & 0,93 \\
\hline
\end{tabular}

Os voluntários foram capazes de aprender as cadeias de Markov de ordem 1 e 2, mas o comportamento deles não é ótimo, pois a estratégia ótima é aquela em que $\mathrm{p}\left(\mathrm{R}_{2}=\mathrm{E} \mid \mathrm{X}_{1}=\mathrm{D}\right)=1$ e $\mathrm{p}\left(\mathrm{R}_{2}=\mathrm{D} \mid \mathrm{X}_{1}=\mathrm{E}\right)=1$ para a ordem 1 e $\mathrm{p}\left(\mathrm{R}_{3}=\mathrm{D} \mid \mathrm{X}_{1}=\mathrm{D}, \mathrm{X}_{2}\right.$ $=\mathrm{D})=1, \mathrm{p}\left(\mathrm{R}_{3}=\mathrm{D} \mid \mathrm{X}_{1}=\mathrm{D}, \mathrm{X}_{2}=\mathrm{E}\right)=0, \mathrm{p}\left(\mathrm{R}_{3}=\mathrm{D} \mid \mathrm{X}_{1}=\mathrm{E}, \mathrm{X}_{2}=\mathrm{D}\right)=0$ e $\mathrm{p}\left(\mathrm{R}_{3}=\mathrm{D} \mid \mathrm{X}_{1}\right.$ $\left.=\mathrm{E}, \mathrm{X}_{2}=\mathrm{N}\right)=1$ para a ordem 2 . Ao invés de "maximizar" desta forma, o comportamento dos voluntários sugere pareamento de probabilidades: ao se comparar as médias da Tabela 11 com os valores equivalentes da Tabela 9 e as médias da Tabela 12 com a primeira coluna da Tabela 10. Os voluntários podem estar procurando padrões na variação aleatória da cadeia de Markov. 


\subsection{Discussão parcial da seção 4}

Os experimentos desta seção têm o objetivo de testar a teoria de que os seres humanos fazem pareamento de probabilidades no experimento de escolha binária repetida porque eles tentam buscar um padrão na sequência de apresentações. $\mathrm{O}$ experimento 1 somente replica os resultados clássicos deste experimento. Nota-se que poucos voluntários se aproximaram da estratégia ótima (maximização), mesmo sendo oferecida a informação de que o resultado de cada apresentação é sorteado independentemente para cada apresentação, não depende das apresentações anteriores. Ou estes voluntários fizeram pareamento de probabilidades por outro motivo além da busca de padrões, ou eles não acreditaram que a sequência não obedecia um padrão, ou ainda eles buscaram por padrões inconscientemente, ainda que conscientemente eles soubessem que não havia padrões. Esta última explicação é corroborada pelos resultados do experimento 2 , de vida artificial, onde vimos que os animais artificiais que evoluíram em um ambiente cujo padrão eles conseguiram aprender faziam pareamento de probabilidades mesmo quando a sequência era aleatória. Da mesma forma, os seres humanos podem ter um viés cognitivo que leva à busca de padrões, conscientemente ou inconscientemente, em qualquer contexto.

As discussões sobre busca de padrões na literatura não abordam a definição de padrão, motivo pelo qual nos dedicamos ao estudo das cadeias de Markov e da teoria da informação. Os experimentos 3 e 4 relevaram que os voluntários fizeram pareamento de probabilidades até mesmo na cadeia de Markov; por exemplo, se, em um dado experimento, depois de um D vinha $\mathrm{E}$ com probabilidade $70 \%$, os voluntários escolhiam E depois de um D aproximadamente 70\% das vezes. Estes experimentos foram a base de outros experimentos que estão sendo realizados em nosso laboratório, envolvendo várias faixas etárias e pacientes com deficiência intelectual, e serão a base de futuros experimentos com seres humanos e animais artificiais. 


\section{ALOCAÇÃO DA ATENÇÃO ESPACIAL}

\subsection{Introdução}

Na introdução, foram citadas duas principais explicações para o fenômeno da atenção seletiva - a capacidade limitada do sistema nervoso e a diferença de relevância dos estímulos para a ação. Com experimentos de vida artificial, podemos, então, testar quais destas explicações causam o surgimento evolutivo de mecanismos de seleção de estímulos.

\subsection{Experimento 5}

Durante o Mestrado, realizamos um experimento que consistia em seis conjuntos de simulações, nos quais variavam (1) o tamanho das redes neurais e (2) a relevância dos diversos estímulos para os animais (FEHER-DA-SILVA, 2005; FEHERDA-SILVA; CATICHA; BALDO, 2008). O objetivo era testar se as redes neurais menores desenvolviam mecanismos de seleção para processar somente os estímulos mais relevantes, pois elas não eram capazes de processar os todos os estímulos que eram apresentados a ela. Além disso, pretendia-se fazer um paralelo entre a evolução dos pesos sinápticos com a mudança de foco da atenção. Durante o doutorado, replicamos esses resultados e estendemos a simulação conforme descrito abaixo.

\subsubsection{Métodos}

Os animais artificiais viviam por 500 unidades de tempo. A cada unidade de tempo, eram apresentados a eles dois objetos, que podiam ser de dois tipos: "comida" ou "não-comida". Os animais podiam escolher se comiam ambos os objetos, só um deles ou nenhum deles, e seu valor adaptativo mudava com cada objeto que eles comiam. Os objetos tinham valores, que eram adicionados ao valor adaptativo quando o objeto era comido; as comidas tinham valores positivos e as não-comidas tinham valores negativos. Não comer nenhum objeto mantinha o valor adaptativo no mesmo valor. 
Iremos nos referir aos dois objetos como os objetos "esquerdo" e "direito", porque eles eram apresentados em diferentes locais nos campos sensoriais dos animais e estimulavam nós de entrada diferentes nas redes neurais. As redes neurais tinham dois nós de entrada, um para cada objeto: o nó de entrada "esquerdo" recebia um estímulo que representava o objeto esquerdo e o nó de entrada “direito" recebia um estímulo que representava o objeto direito. Dois nós de saída determinavam se o animal comeria cada um dos objetos apresentados: o nó de saída esquerdo determinava se o animal comeria o objeto esquerdo e o nó de saída direito determinava se o animal comeria o objeto direito.

Além dos nós de entrada e saída, as redes neurais também tinham um número variável de nós ocultos, que determinavam se elas tinham ou não capacidade suficiente para processar os dois estímulos. As relevâncias evolucionárias dos objetos esquerdo e direito também podiam variar dependendo de como eles afetavam o valor adaptativo quando ingeridos. Nós comparamos o processamento sensorial em animais com ou sem capacidade limitada, que evoluíram em simulações em que os objetos tinham relevâncias iguais ou diferentes.

Se a seleção é uma solução para um problema de capacidade limitada, nós esperamos que a seleção só irá surgir em populações onde os animais têm capacidade limitada.

\subsubsection{Redes neurais}

Os animais tinham redes neurais alimentadas adiante e totalmente conectadas com dois nós lineares de entrada, um número variável de nós ocultos, conforme especificado mais adiante, e dois nós de saída. Cada nó de entrada era estimulado com um número no intervalo $[-1 ; 1)$, que indicava uma comida se o número também era um elemento do intervalo $[-0,3 ; 0,3)$ e uma não-comida caso contrário. Os nós ocultos e os nós de saída eram perceptrons, conforme descrito no item 3.1, página 35. As saídas dos dois nós de saída determinavam se o animal comia cada um dos dois objetos. Se a saída do nó esquerdo era maior do que zero, o animal comia o objeto esquerdo; caso contrário, aquele objeto não era comido. A mesma regra era aplicada ao nó de saída e ao objeto direitos. Os vieses dos neurônios e os pesos sinápticos eram determinados pelos cromossomos dos animais. Os pesos sinápticos eram constantes du- 
rante a vida de um animal (não havia aprendizado), mas podiam mudar por mutação ao longo das gerações.

\subsubsection{Conjuntos de simulações}

Em vários conjuntos de simulações, nós estudamos o efeito de dois fatores na emergência de mecanismos de seleção: o número de nós ocultos na rede neural e as relevâncias dos estímulos para a ação (Tabela 13). O número de nós ocultos podia ser dois, quadro ou oito. Dois nós ocultos não são suficientes para a identificação correta de ambos os estímulos o tempo todo. Estes animais tinham que processar somente um estímulo totalmente ou ambos parcialmente; estas redes neurais tinham capacidade limitada. Redes neurais com quatro oito nós internos tinham a capacidade de identificar corretamente ambos os estímulos o tempo todo; estes animais não tinham capacidade limitada.

De fato quatro nós internos são necessários e suficientes para a identificação de ambos os estímulos, porque os nós ocultos e os nós de saída são perceptrons: eles separam o espaço de entrada por um hiperplano em duas categorias. Dois nós ocultos são necessários para identificar um estímulo: um nó para classificá-lo como maior do que $-0,3$ ou não e outro nó para classificá-lo como maior do que 0,3 ou não. Assim, com dois nós ocultos, era possível identificar uma comida, que era representada por um estímulo no intervalo $[-0,3 ; 0,3)$. Esta é a única maneira que um nó de saída pode responder de maneira diferente a comidas e não-comidas. Os estímulos à esquerda e à direita tinham que ser processados por diferentes nós a fim de serem corretamente identificados, pois os dois estímulos eram independentes. Como havia dois objetos a serem identificados, uma rede neural precisaria então de quatro nós ocultos, dois para cada objeto. De fato, nós fomos capazes de demonstrar que uma rede neural

Tabela 13 - Conjuntos de simulações do experimento 5.

\begin{tabular}{l|l|l|l|l|l|l}
\hline \multirow{2}{*}{\multicolumn{1}{c|}{ Variáveis }} & \multicolumn{7}{c}{ Conjuntos de simulações } \\
\cline { 2 - 8 } & $2-6-6$ & $4-6-6$ & $8-6-6$ & $2-11-1$ & $4-11-1$ & $8-11-1$ \\
\hline Número de nós ocultos & 2 & 4 & 8 & 2 & 4 & 8 \\
\hline Valor inicial da comida esquerda & 6 & 6 & 6 & 11 & 11 & 11 \\
\hline Valor inicial da comida direita & 6 & 6 & 6 & 1 & 1 & 1 \\
\hline
\end{tabular}


com quatro nós internos que era capaz de identificar corretamente os dois objetos o tempo todo (FEHER-DA-SILVA, 2005).

Além do número de nós ocultos, as relevâncias dos estímulos para a ação podiam variar nos diferentes conjuntos de simulações. As relevâncias dos estímulos à esquerda e à direita eram definidas pela variação do valor adaptativo do animal quando este comia os objetos que eles representavam (no caso de os objetos serem comida; no caso contrário, quando o animal comia uma não-comida, o valor adaptativo variava sempre com o mesmo valor de -3 , independentemente do lado onde estava o objeto).

Assim, os estímulos à esquerda e à direita tinham a mesma relevância quando o valor era o mesmo tanto por uma comida localizada à esquerda quanto à direita (por exempo, +6 à direita e também +6 à esquerda). Os estímulos tinham diferentes relevâncias quando o valor de uma comida de um lado diferia da comida do outro lado (por exemplo, +1 à direita e +11 à esquerda ou, inversamente, +11 à direita $\mathrm{e}+1$ à es querda). Note que o valor total possível de ser obtido pelo animal, em qualquer dos casos, é sempre o mesmo: $6+6=1+11=11+1$.

Os conjuntos de simulações tinham rótulos tais como "2-11-1": o primeiro número era o número de nós internos na rede neural (2 neste exemplo), o segundo número era o valor inicial das comidas à esquerda (11 neste exemplo) e o terceiro número era o valor inicial das comidas à direita (1 neste exemplo). Na segunda metade de cada simulação, os valores das comidas à direita e à esquerda foram trocados. Cada simulação era executada por 40 mil gerações, tal que durante as primeiras 20 mil gerações as comidas à esquerda eram mais valiosas do que as comidas à direita e nas últimas 20 mil gerações, as comidas à direita se tornavam mais valiosas do que as comidas à esquerda. Devido aos resultados obtidos na simulação 8-11-1, também fizemos uma variação dela que alcançava 80 mil gerações, sem que o valor das comidas à direita e à esquerda fosse modificado na geração 20 mil (veja a discussão parcial).

Cada conjunto de simulações consistia de dez simulações. Elas eram idênticas exceto pela semente usada para iniciar o gerador de números aleatórios; como consequência, os valores iniciais dos genes eram, em geral, diferentes. Nós queríamos averiguar se os resultados seriam consistentes dentro de um conjunto de simulações, $\mathrm{o}$ que indicaria que as diferenças entre as simulações eram devidas a diferentes parâmetros, e não a fatores fortuitos (acidentes históricos durante o curso das simulações). 


\subsubsection{Evolução}

A evolução de redes neurais foi simulada por um algoritmo genético. Cada animal vivia por 500 unidades de tempo e seus valores adaptativos eram computados durante suas vidas de acordo com o número de comidas e não-comidas que eles comiam. Os cromossomos eram vetores de números reais pertencentes ao intervalo [-1, 1), inicialmente sorteados com distribuição uniforme, que determinavam os vieses e os pesos sinápticos das redes neurais. Havia um gene para cada viés e um gene para cada peso sináptico.

Durante cada simulação, dez populações de vinte indivíduos evoluíam em paralelo por 40 mil gerações. Para criar uma nova população, usamos seleção por torneio, elitismo, mutação, crossover e migração a cada 200 gerações.

\subsubsection{Análise}

Ao analisar o d' das redes neurais, foi possível determinar quais estímulos as redes neurais processavam e corretamente identificavam. As taxas de acertos e de falsos alarmes foram calculadas para os animais da seguinte forma: 100 números distribuídos uniformemente no intervalo $[-1,1)$ foram gerados e então combinados em pares, gerando todos os pares possíveis (10 mil no total), e os pares foram usados como entrada para os dois nós de entrada das redes neurais. A resposta de uma rede neural a cada par de estímulo era gravada e a taxa de acertos e de falsos alarmes era computada para os objetos esquerdo e direito separadamente. Quando um animal comia uma comida, isto era um acerto. Quando o animal comida uma não-comida, isto era um alarme falso. Então o d' era calculado independentemente para os estímulos à es querda e para os estímulos à direita.

\subsubsection{Resultados e Discussão Parcial}

Os resultados estão mostrados nas figuras abaixo. 


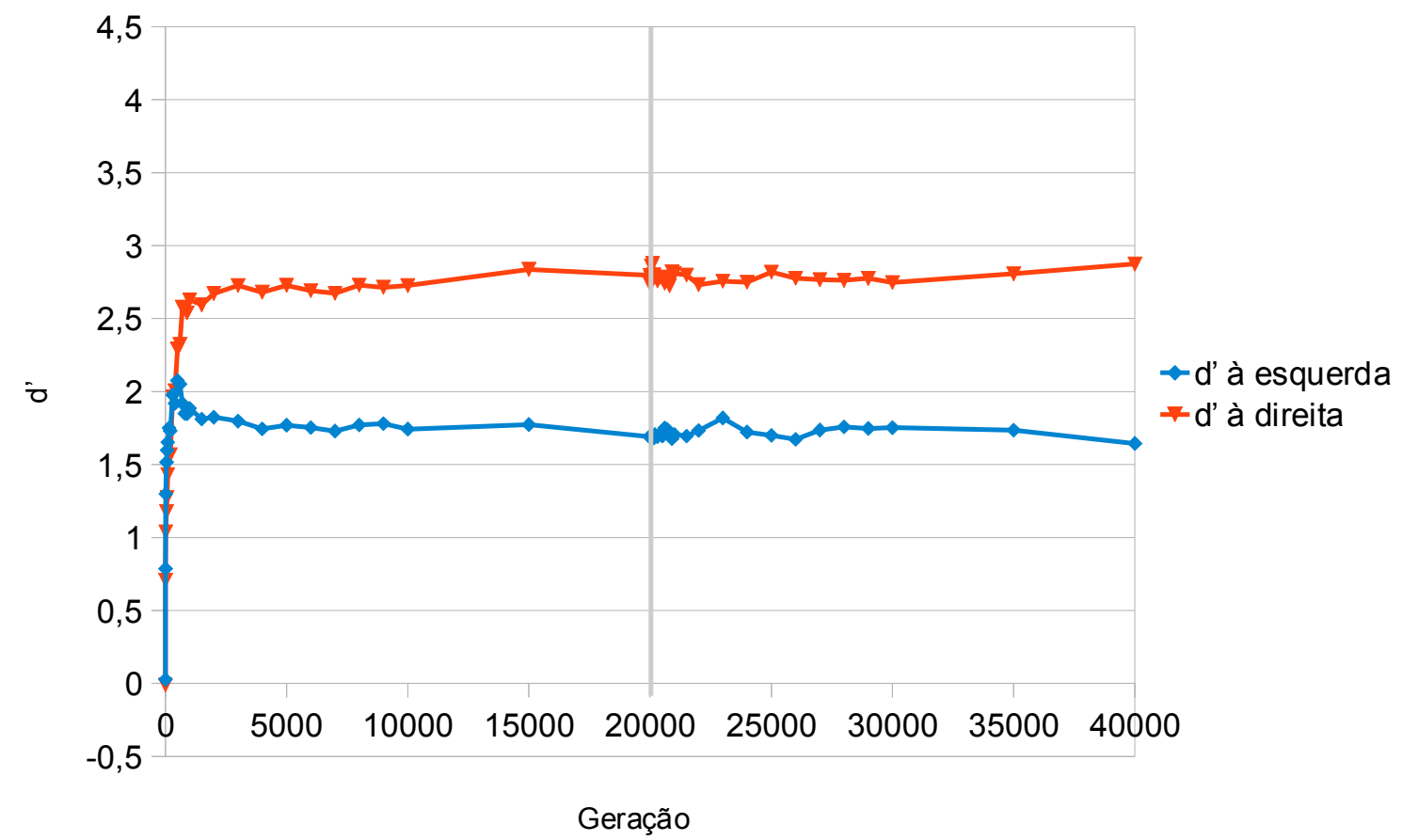

Figura 13 - Evolução do d' médio para os estímulos à esquerda e à direita para o conjunto de simulações 2-6-6.

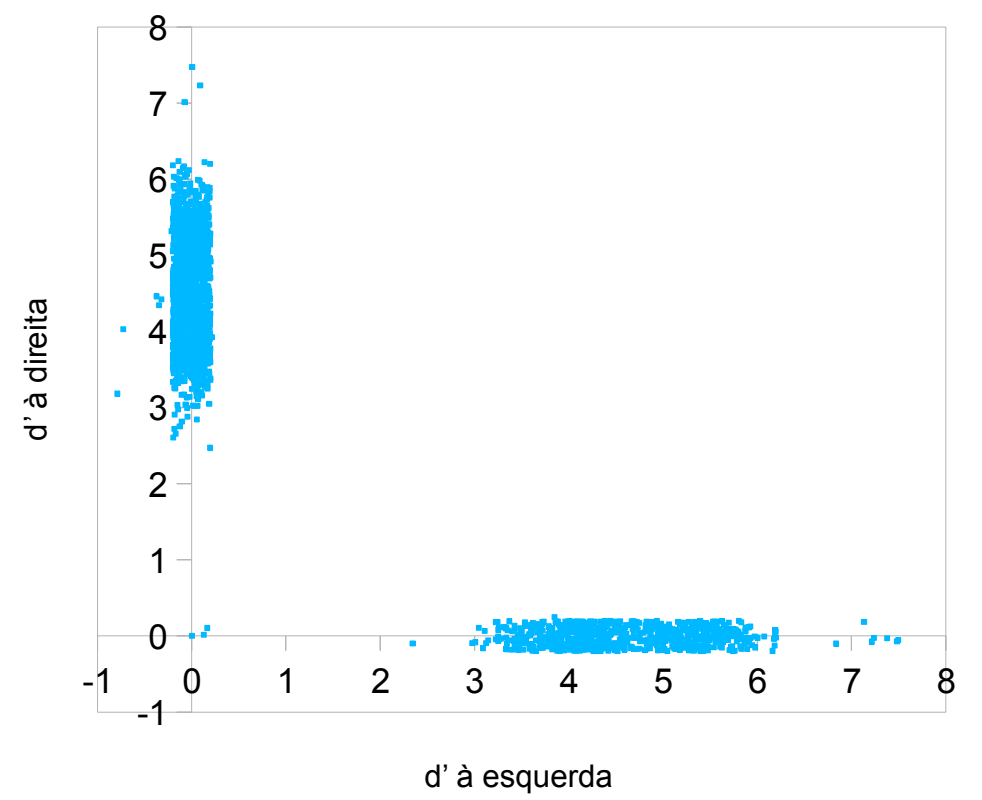

Figura 14 - $d^{\prime}$ para os estímulos esquerdo e direito para os animais da geração 40,000 do conjunto de simulações 2-6-6. Cada ponto na figura representa um animal. Números aleatórios com distribuição uniforme entre -0,2 e 0,2 foram adicionados a todos os valores para que os pontos pudessem ser melhor visualizados no gráfico. 


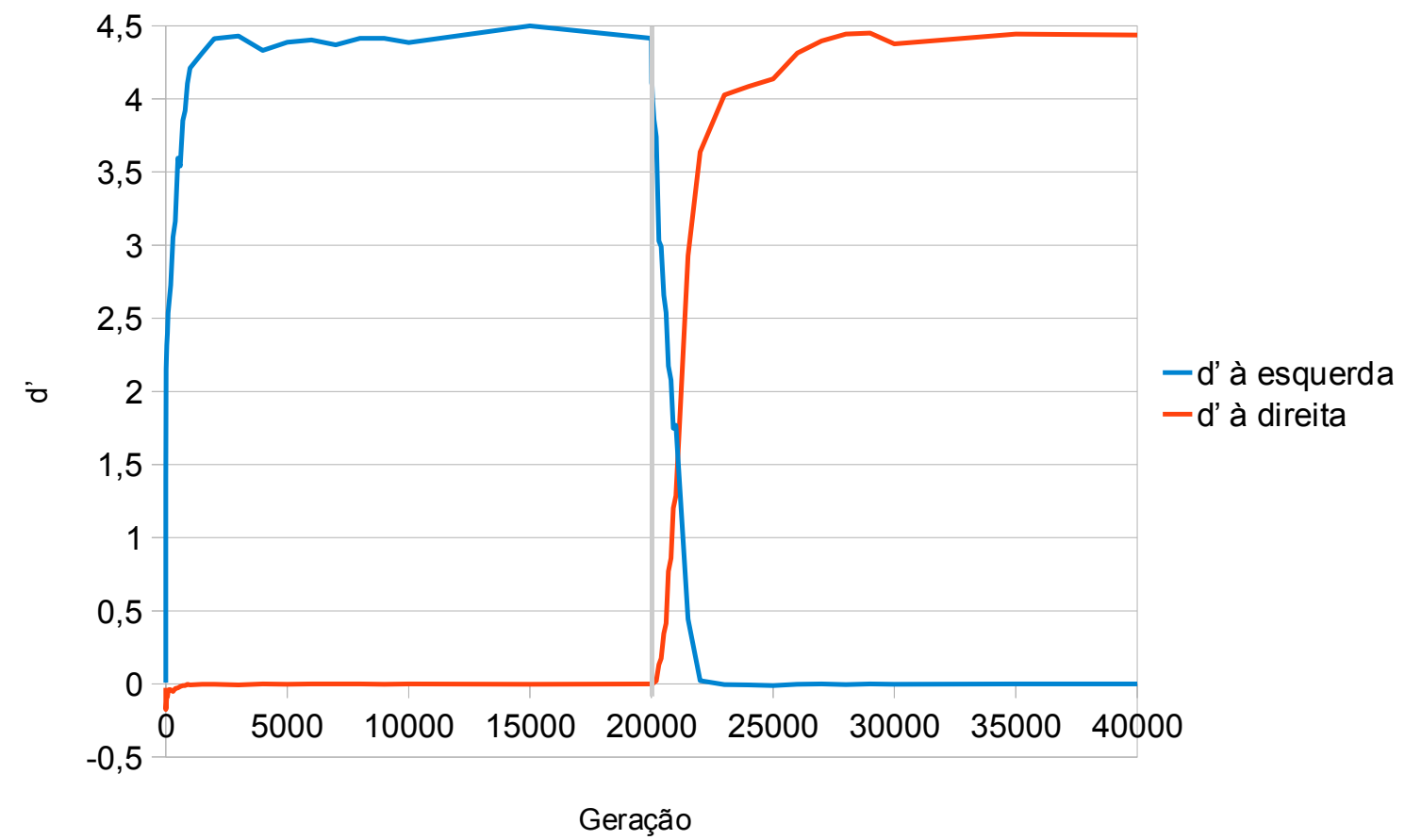

Figura 15 - Evolução do d' médio para os estímulos à esquerda e à direita para o conjunto de simulações 2-11-1.

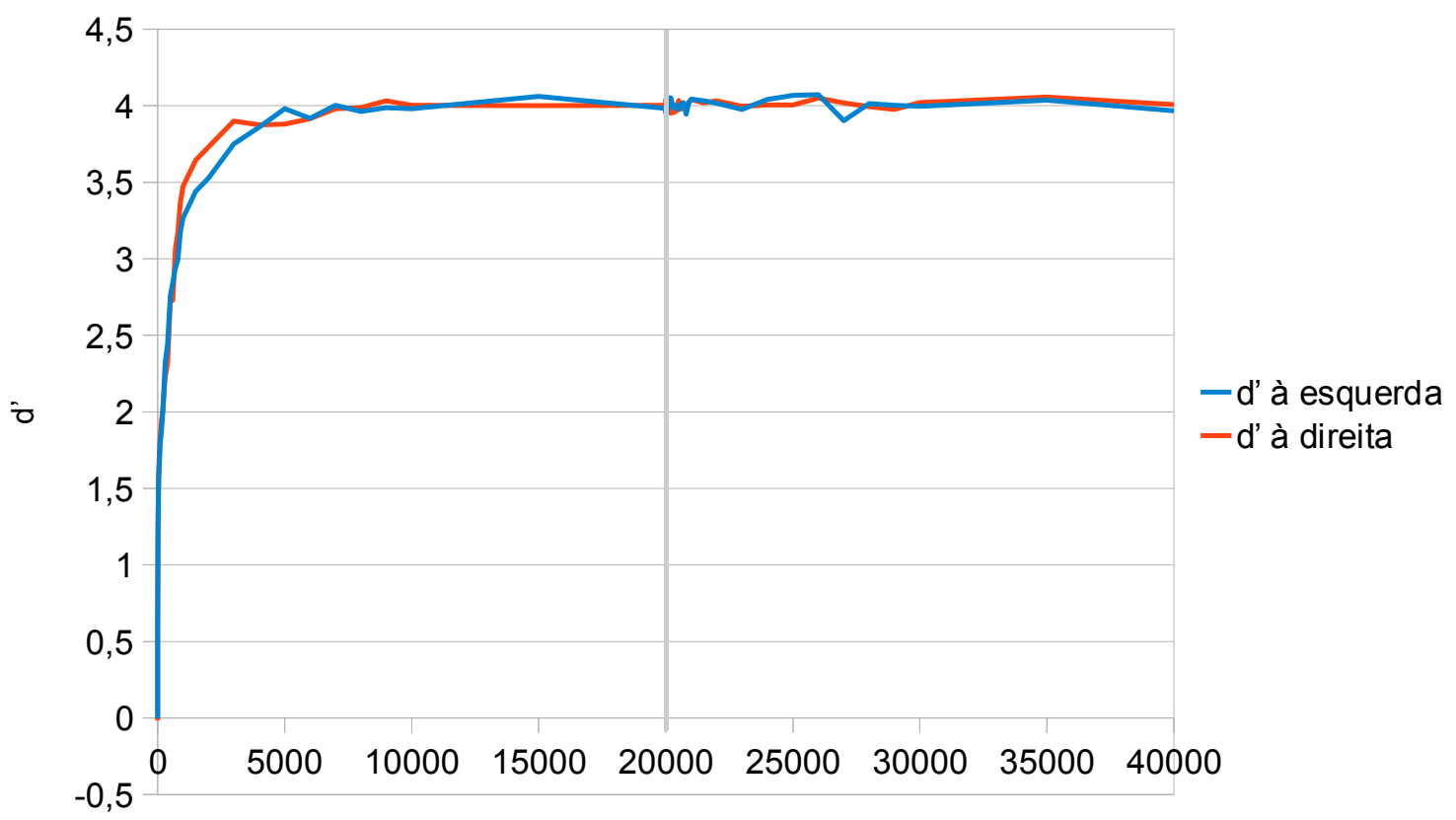

Geração

Figura 16 - Evolução do d' médio para os estímulos à esquerda e à direita para o conjunto de simulações 4-6-6. 


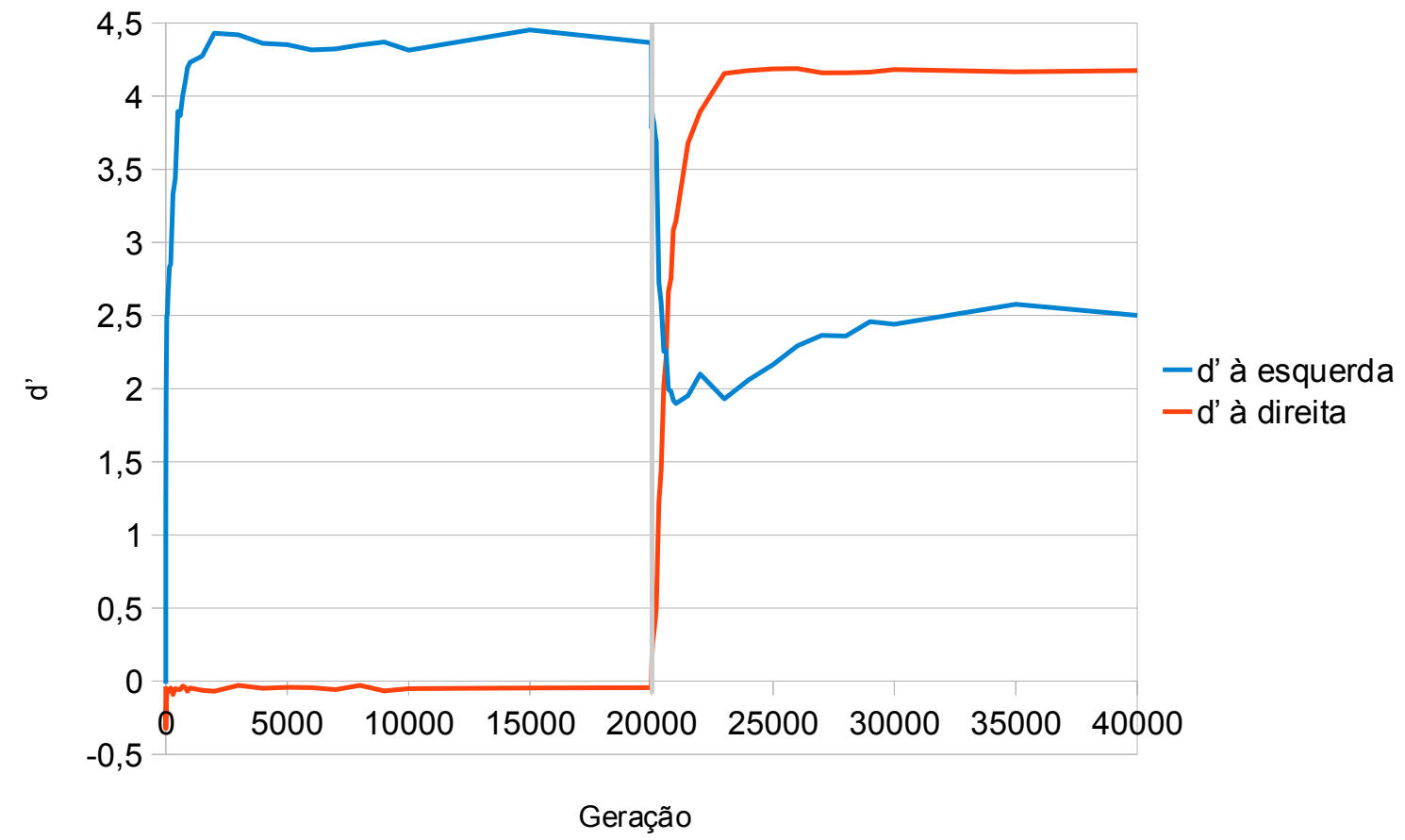

Figura 17 - Evolução do d' médio para os estímulos à esquerda e à direita para o conjunto de simulações 4-11-1.

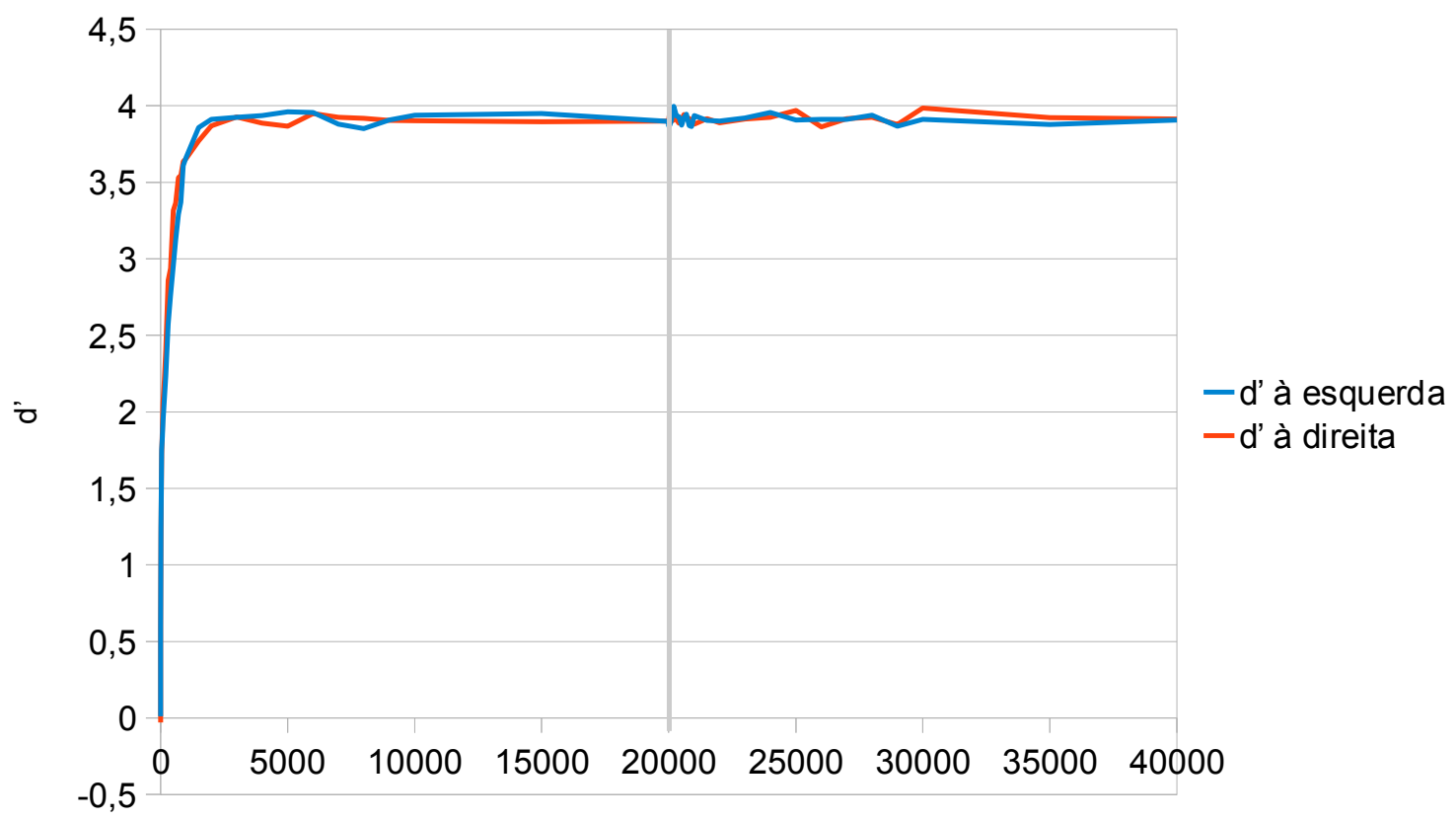

Geração

Figura 18 - Evolução do d' médio para os estímulos à esquerda e à direita para o conjunto de simulações 8-6-6. 


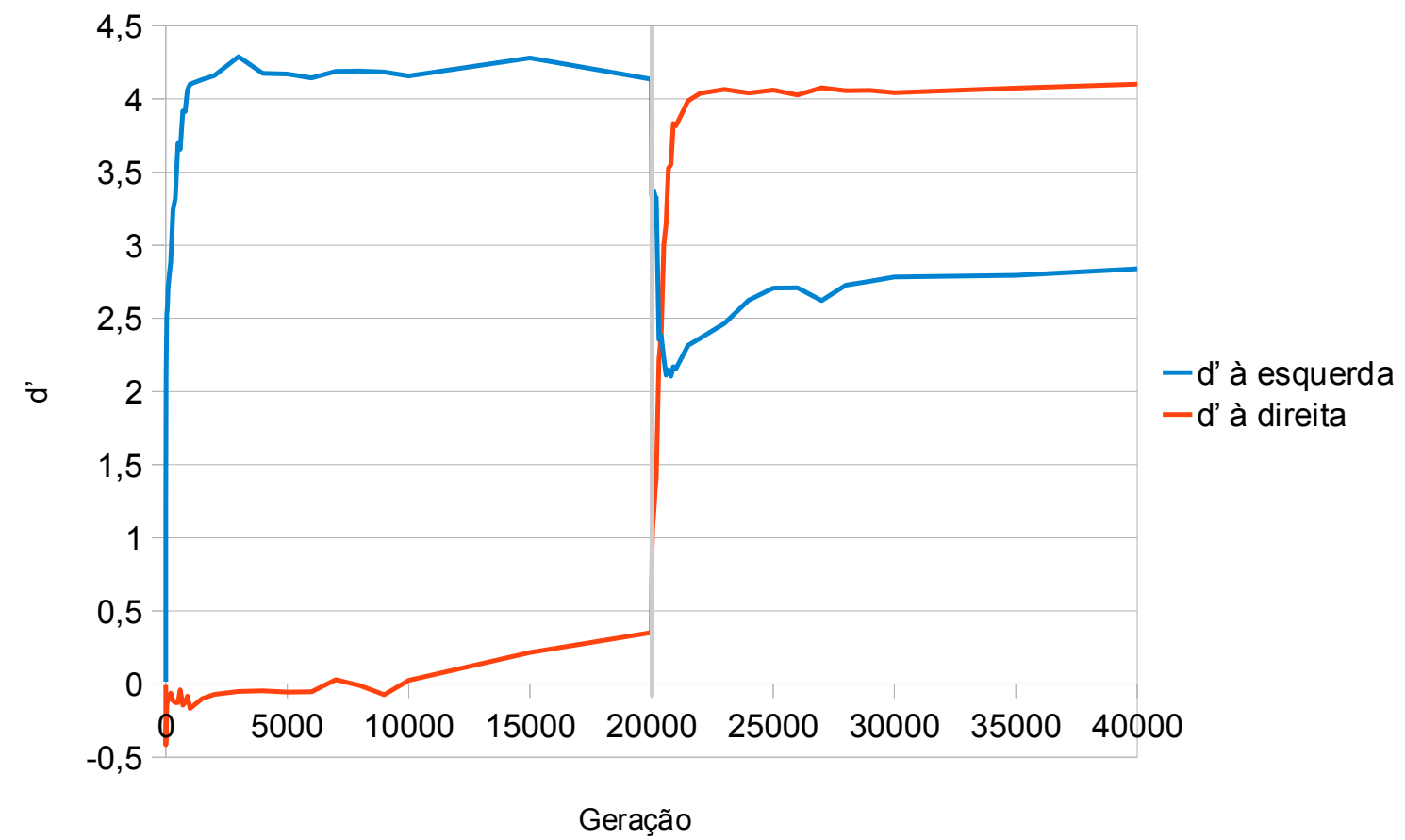

Figura 19 - Evolução do d' médio para os estímulos à esquerda e à direita para o conjunto de simulações 8-11-1.

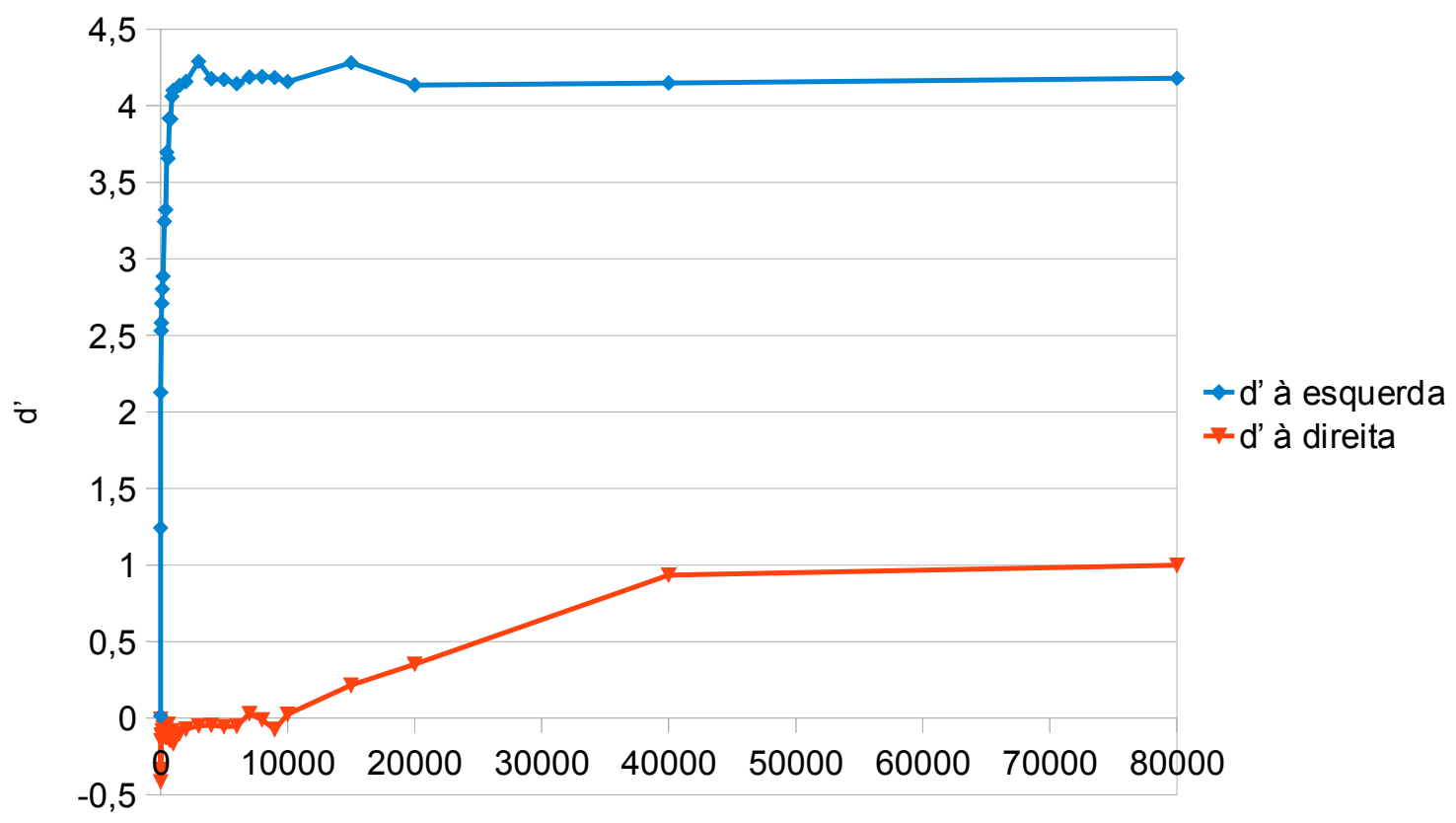

Geração

Figura 20 - Evolução do d' médio para os estímulos à esquerda e à direita para o conjunto de simulações 8-11-1 sem a inversão na relevância dos estímulos na geração 20 mil. 
Nós demonstramos matematicamente que redes neurais com somente dois nós ocultos não são capazes de identificar os dois objetos corretamente o tempo todo (FEHER-DA-SILVA, 2005). Nenhuma simulação era necessária para mostrar que estes animais não atingiriam um d' alto para ambos os estímulos; seria impossível. Quais estímulos eram inicialmente processados e quais eram inicialmente ignorados dependia das relevâncias dos mesmos. Quando os estímulos à esquerda eram os mais relevantes, eles eram processados.

Os resultados mostrados nas Figuras 13 e 14 são de simulações em que ambos os estímulos tinham a mesma relevância. Olhando somente para a Figura 13, poderse-ia pensar que os animais destas simulações processavam os dois estímulos parcialmente, já que o d' para os objetos esquerdos e direitos, nestas simulações, estavam entre 1,5 e 3 (um d' entre 4 e 4,5 significava uma alta acurácia neste experimento, conforme se observa nos resultados das outras simulações). Também poder-se-ia pensar que os animais estavam, por algum motivo, dando mais prioridade aos objetos à direita. As duas conclusões são incorretas. A Figura 14 demonstra que os animais não processavam os dois estímulos parcialmente; ao invés disso, duas subpopulações distintas emergiram, que processavam somente os estímulos à esquerda ou somente os estímulos à direita (Figura 14). Os animais exibiam uma condição semelhante à heminegligência em animais biológicos. E apesar de nesta amostra de simulações 2-6-6 o valor de d' para os objetos direitos ter sido em média maior do que o valor de d' para os objetos esquerdos, todas as simulações em que os dois objetos valem 6 foram projetadas para serem exatamente simétricas, sendo portanto quaisquer diferenças observadas nas simulações 2-6-6, bem como nas simulações 4-6-6 ou 8-6-6, consequências do acaso, ou seja, elas só existem por causa de uma amostra pequena $(n=10)$ de simulações de um conjunto. Assim, é correto dizer que os animais tinham igual probabilidade de processar somente os estímulos à esquerda ou somente os estímulos à direita.

Nas simulações 2-11-1, as redes neurais processavam somente os estímulos mais relevantes com alta acurácia e ignoravam os estímulos do outro lado. Quando as relevâncias dos estímulos eram trocadas na geração 20 mil, as redes em 2-11-1 foram capazes de mudar quais estímulos eram processados para que eles fossem sempre os mais relevantes.

Nas simulações 4-6-6 e 8-6-6 (Figuras 16 e 18), os animais foram capazes de processar os dois estímulos com alta acurácia $\left(\mathrm{d}^{\prime}=4\right)$, conforme esperado, mas as outras 
simulações tiveram resultados surpreendentes. Baseado na teoria da capacidade limitada, poderíamos supor que nos conjuntos de simulações 4-11-1 e 8-11-1 (Figuras 17 e 19), os animais seriam capazes de identificar ambos os estímulos corretamente, já que eles tinham capacidade suficiente para processar todas as entradas sensoriais. Porém, enquanto que o d' para os estímulos à esquerda, que eram inicialmente os mais relevantes, atingiram seu valor máximo em algumas gerações, o d' para os estímulos à direita elevou-se pouco e lentamente no caso das simulações 8-11-1, não passando do zero nas simulações 4-11-1. Quando as relevâncias foram trocadas, o d' para os estímulos à direita subiu a níveis máximos, mas o d' para os estímulos à esquerda reduziu-se a níveis intermediários $\left(\mathrm{d}^{\prime}=2,5\right)$, ou seja, os animais perderam a capacidade de processar os estímulos menos relevantes com alta acurácia. Este resultado não pode ser explicado pela capacidade limitada de processamento. Nota-se que as redes neurais maiores, com oito nós internos, tiveram uma pequena vantagem em relação ao processamento dos estímulos menos relevantes em relação às redes neurais com quatro nós internos. Dado o lento crescimento do d' para os estímulos à direita que se vê na primeira metade das simulações 8-11-1, surge a dúvida do que aconteceria se as relevâncias dos estímulos não fossem alteradas na geração 20 mil e as simulações rodassem por mais tempo. Iria o d' para os estímulos à direita crescer gradualmente até atingir o nível do d' para os estímulos à esquerda? Os resultados da Figura 20 sugerem que não. Após 80 mil gerações, o d' para os estímulos à direita parecem ter se estacionado por volta do valor 1 .

Em resumo, o processamento de estímulos à direita foi reduzido não somente quando as redes neurais tinham capacidade limitada, mas também quando aqueles estímulos tinham pouca relevância. Assim, parece que um maior d' inicial para os estímulos à direita não era uma vantagem evolutiva importante e mutações que aumentavam o processamento daquele estímulo podiam se perder facilmente durante a reprodução. Com capacidade suficiente para o processamento da informação, pode ter havido pouca necessidade de seleção, mas havia também pouca necessidade de circuitos capazes de identificar estímulos pouco importantes. Com pouca pressão seletiva, estruturas complexas não se desenvolvem. Os animais são selecionados por suas ações, sendo a percepção importante só quando possui consequências sobre essas ações. Mesmo uma capacidade infinita para processar informações não seria útil sem a habilidade de transformar esta informação em ações adaptativas. Novos mecanismos para o processamento da informação só podem coevoluir com a habilidade 
de tomar decisões melhores - e gerar ações melhores - baseadas nesta informação. Se um conjunto de estímulos é completamente irrelevante, não há pressão evolutiva para processá-los e todos os animais obterão o mesmo valor adaptativo independentemente do que suas redes neurais fizerem com estes estímulos. Então, de acordo com a teoria da evolução, nenhuma estrutura para processar estes estímulos irá surgir.

Os nossos resultados também não puderam ser previstos pela teoria da seleçãopara-a-ação, que diz que os estímulos irrelevantes para a ação devem ser inibidos a fim de que a ação seja coerente. Nossas redes neurais eram capazes de executar duas ações independentemente, comer ou não comer o objeto à esquerda e comer ou não comer o objeto à direita. É verdade que o processamento dos estímulos à direita deveria ser inibidos pelos neurônios que processavam os estímulos à esquerda, pois os estímulos à direita não carregavam nenhuma informação sobre os objetos à esquerda. Mas o processamento dos estímulos à direita não deveria ter que ser inibido em toda a rede neural. Os outros nós, que não são necessários para processar os estímulos à esquerda, estavam livres para processar os estímulos à direita. Ainda assim, o processamento destes estímulos foi inibido parcialmente.

\subsection{Experimento 6}

No experimento acima, os animais com dois nós na camada interna da rede neural processavam apenas um dos estímulos (à direita ou à esquerda), mesmo quando eles tinham a mesma relevância. Eles poderiam também processar os dois estímulos parcialmente, mas não o fizeram. Isso provavelmente ocorreu porque, dados os parâmetros do experimento, é mais vantajoso processar um estímulo inteiramente do que os dois estímulos parcialmente, pois um estímulo é um número entre -1 a 1, sendo que as comidas eram números entre $-0,3$ a 0,3. Assim, a frequência de comida é 0,3 . Sabemos que um perceptron é um separador linear, ou seja, ele é capaz de dividir o intervalo de -1 a 1 em dois intervalos menores. Um só perceptron não é capaz de diferenciar comida de não-comida, pois para isso seria necessário dividir o intervalo de -1 a 1 em três intervalos menores: de -1 a $-0,3$, de $-0,3$ a 0,3 e de 0,3 a 1 . Deste modo, o animal com dois nós ocultos pode processar só um estímulo inteiramente, ou seja, usar um nó oculto para classificar um estímulo como maior ou menor do que -0,3 e usar o outro nó oculto para classificar o mesmo estímulo como maior ou menor do 
que 0,3; assim o animal pode diferenciar entre comida e não-comida de um lado perfeitamente, mas não obter nenhuma informação quanto ao estímulo do outro lado. $\mathrm{O}$ animal com dois nós ocultos também pode processar os dois estímulo parcialmente, ou seja, usar um nó oculto para processar um estímulo como maior ou menor do que $-0,3$ (ou 0,3 ) e usar o outro nó oculto para processar o outro estímulo como maior ou menor do que -0,3 (ou 0,3); dessa forma, o animal obtém uma informação parcial dos dois lados, podendo comer todas as comidas de ambos os lados, mas também comendo metade das não-comidas dos dois lados por não ser capaz de diferenciá-las das comidas. A esperança do valor adaptativo de um animal que processa um estímulo inteiramente (heminegligência), assumindo que a comida tem valor +6 , é portanto 0,3 $\times 6=1,8$. Já a esperança do valor adaptativo de um animal que processa os dois estímulos parcialmente, assumindo que a comida tem valor +6 , é portanto $2 \times 0,3 \times 6-2$ $\times 0,35 \times 3=1,5$. Desta forma, o animal consegue mais pontos quando processa só um dos estímulos inteiramente, daí o resultado observado.

Repetimos, portanto, este mesmo experimento agora mudando a frequência de comida para 0,4 e o valor da não-comida para -2. Desta forma, a esperança do valor adaptativo de um animal que processa um estímulo inteiramente (heminegligência), assumindo que a comida tem valor +6 , é $0,4 \times 6=2,4$. A esperança do valor adaptativo de um animal que processa os dois estímulos parcialmente, assumindo que a comida tem valor +6 , é $2 \times 0,4 \times 6-2 \times 0,3 \times 2=3,6$. Agora o animal conseguirá mais pontos quando processar os dois estímulos parcialmente e o resultado esperado é que os animais do conjunto de simulações 2-6-6 processem os dois estímulos parcialmente e não desenvolvam nada parecido com heminegligência, como no experimento 1.

\subsubsection{Métodos}

Os detalhes das simulações são basicamente os mesmos descritos anteriormente, estando as diferenças na frequência de comida e no valor da não-comida, como explicamos. Cada animal vive por 200 unidades de tempo. Dez populações de vinte animais cada evoluem em paralelo e há migração a cada 200 gerações. Cada simulação roda por 40 mil gerações e há inversão das relevâncias dos estímulos após 20 mil gerações. Para determinar o d' dos animais para os estímulos à direita e à esquerda, eles foram testados com um conjunto de estímulos conforme explicado para o experi- 
mento anterior, mas usando-se 20 números distribuídos uniformemente no intervalo $[-1,1)$, que foram combinados em pares, gerando todos os pares possíveis (400 no total).

\subsubsection{Resultados e Discussão Parcial}

Os resultados deste experimento são mostrados nas figuras a seguir. 


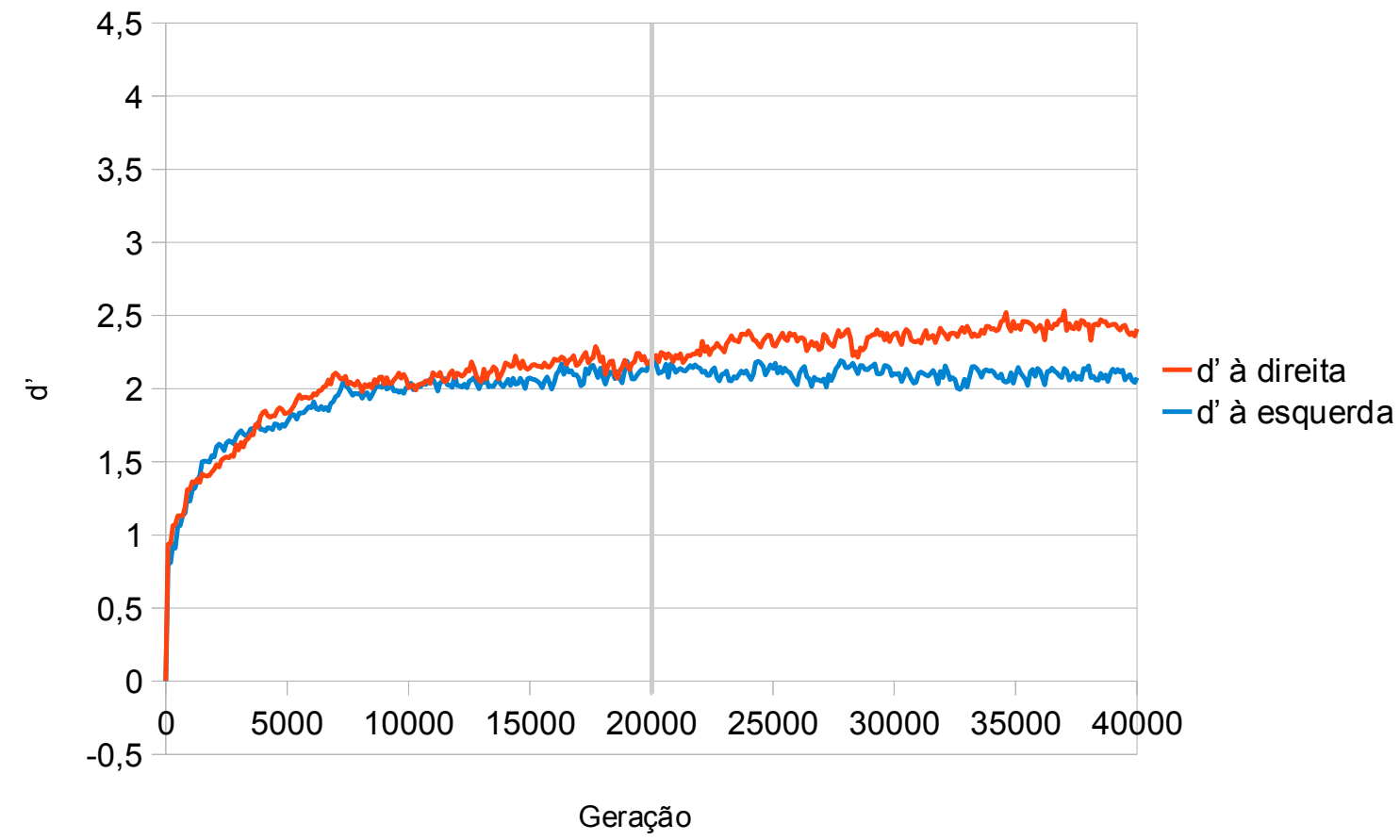

Figura 21 - Evolução do d' médio para os estímulos à esquerda e à direita para o conjunto de simulações 2-6-6.

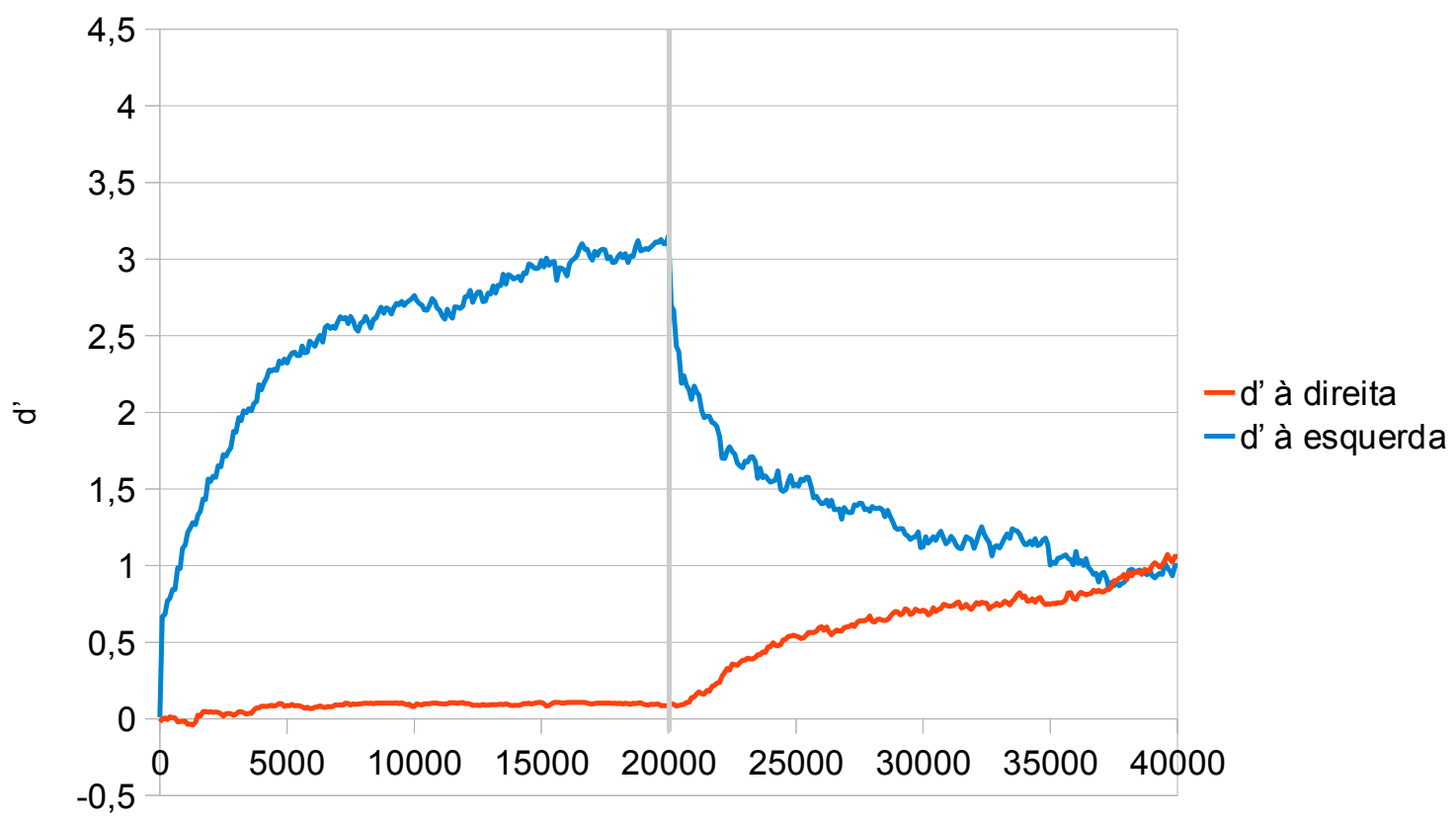

Geração

Figura 22 - Evolução do d' médio para os estímulos à esquerda e à direita para o conjunto de simulações 2-11-1. 


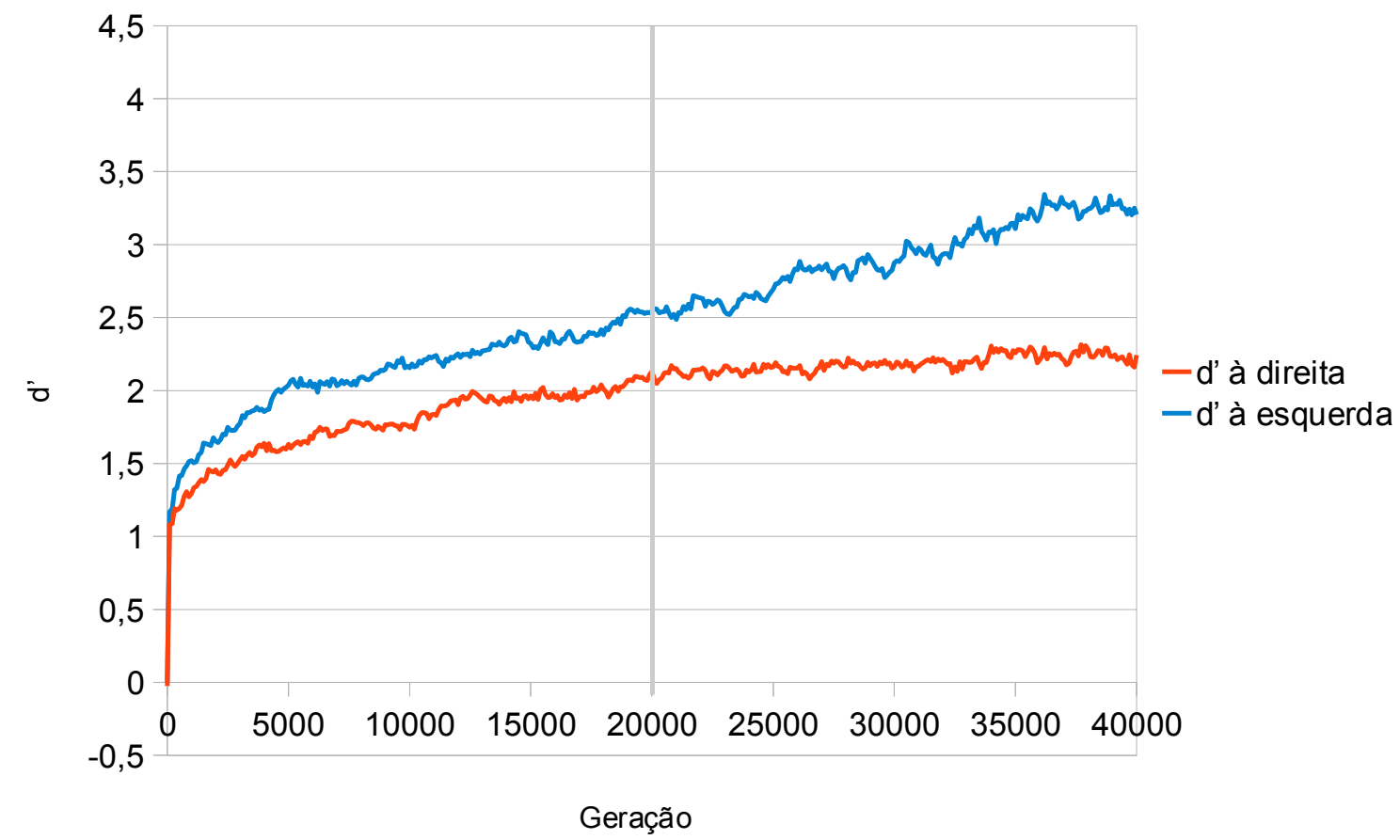

Figura 23 - Evolução do d' médio para os estímulos à esquerda e à direita para o conjunto de simulações 4-6-6.

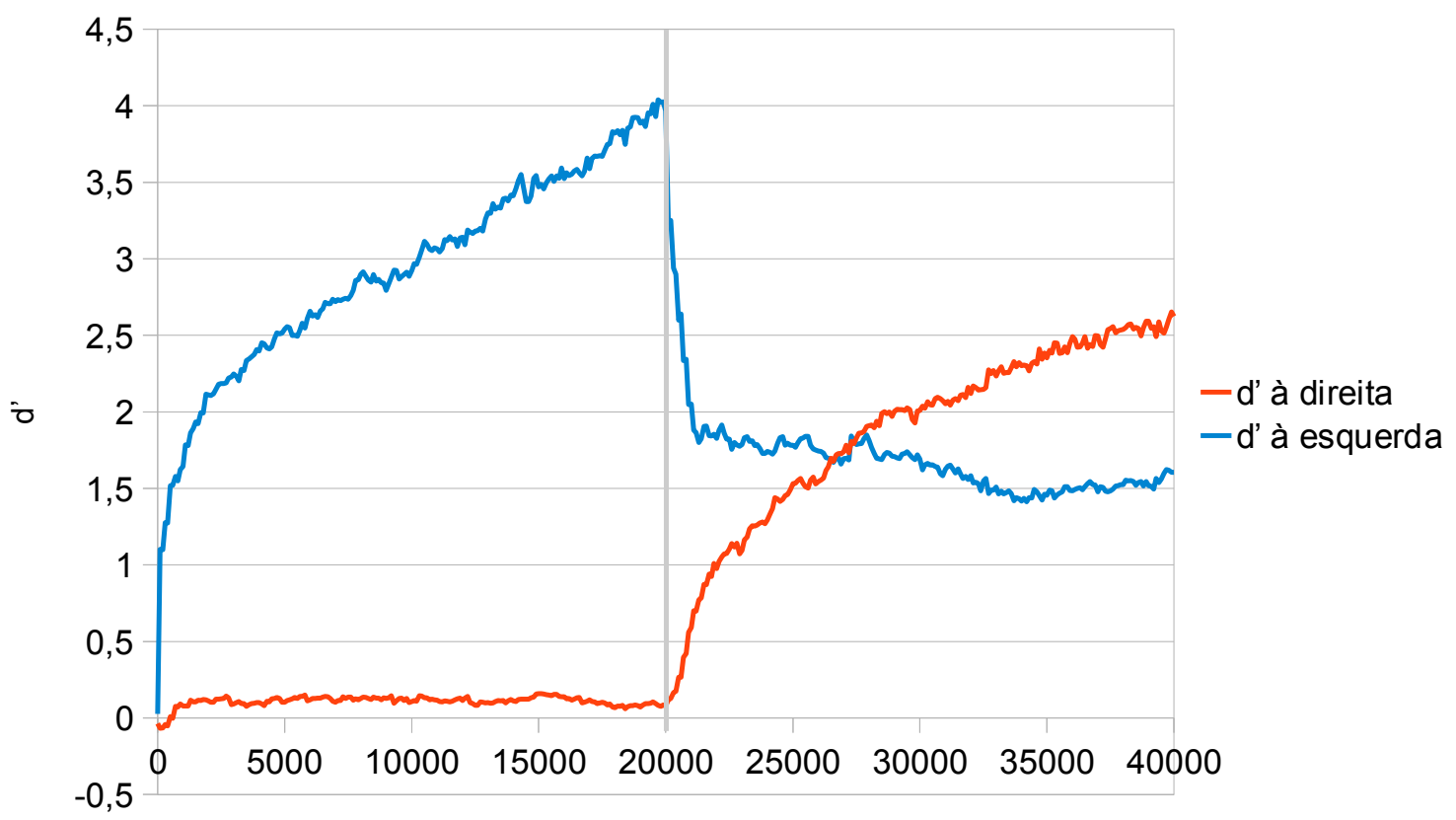

Geração

Figura 24 - Evolução do d' médio para os estímulos à esquerda e à direita para o conjunto de simulações 4-11-1. 


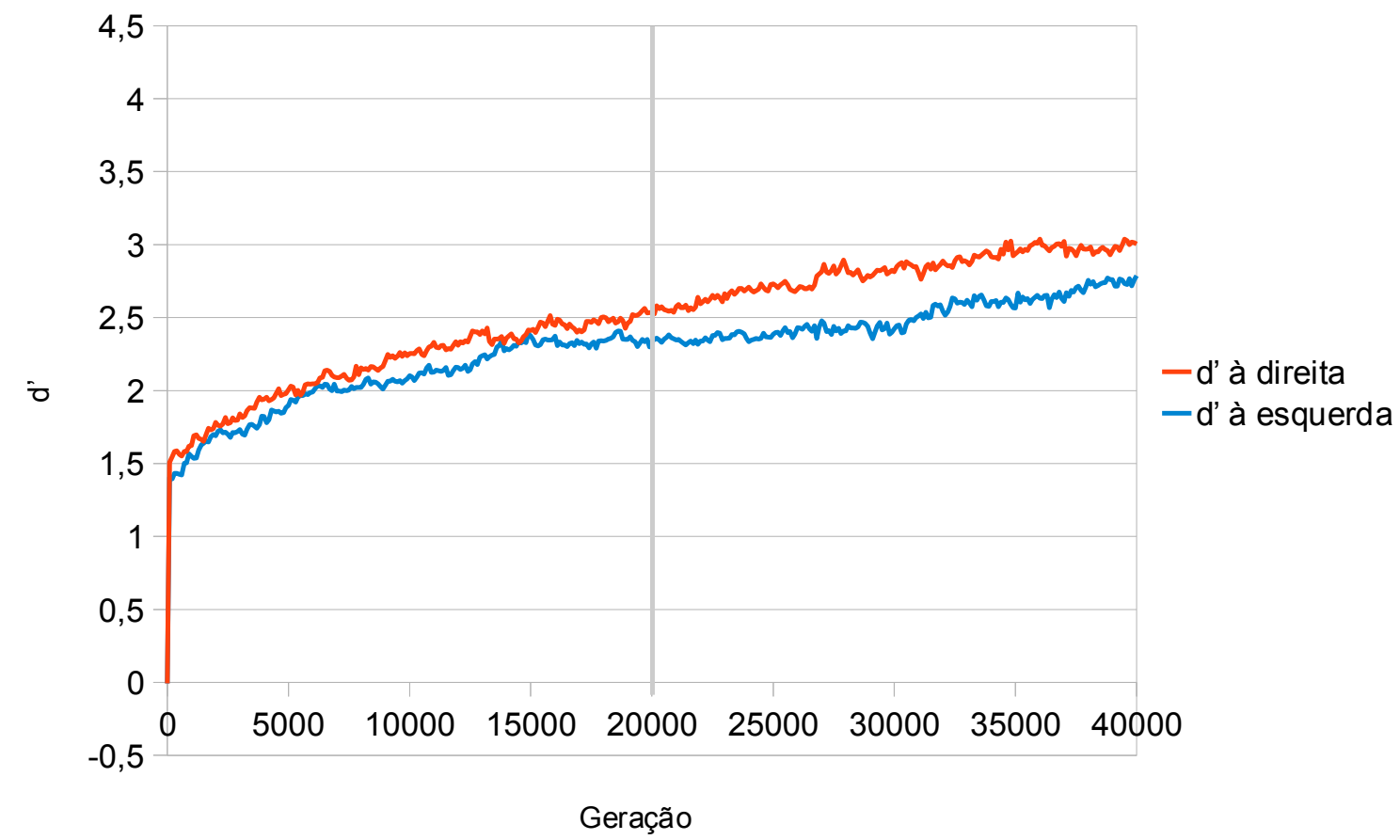

Figura 25 - Evolução do d' médio para os estímulos à esquerda e à direita para o conjunto de simulações 8-6-6.

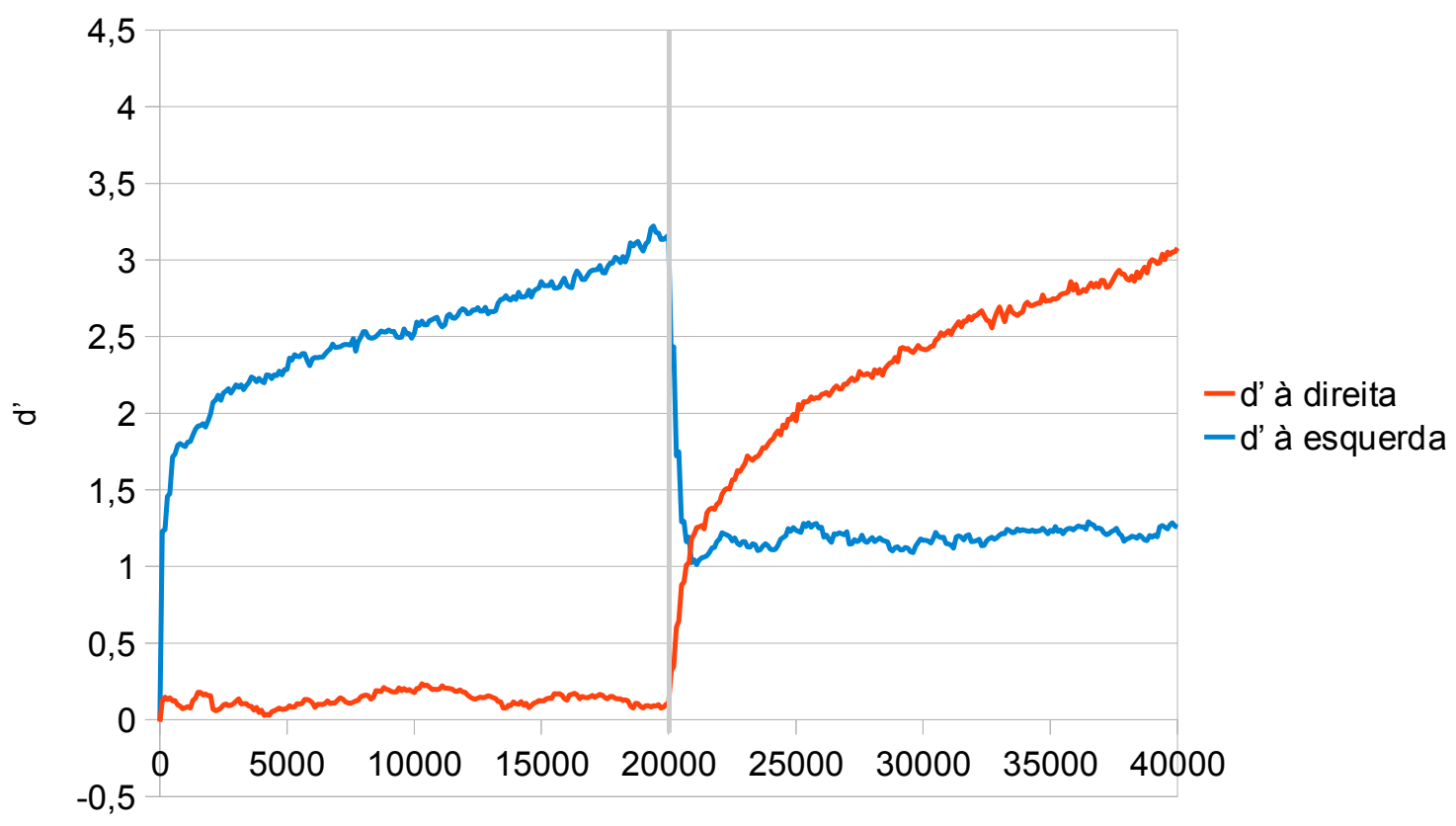

\section{Geração}

Figura 26 - Evolução do d' médio para os estímulos à esquerda e à direita para o conjunto de simulações 8-11-1. 
Os resultados da Figura 21 (simulações 2-6-6 deste experimento) lembram os da Figura 13 (simulações 2-6-6 do experimento anterior), mas no experimento anterior as médias da detectabilidade mostradas escondem o fato de que os animais da última geração daquela simulação se dividem em dois grupos: os dois animais que só processam o estímulo à direita e os que só processam o estímulo à esquerda (eles exibem heminegligência). Nesta simulação, como prevíamos, as médias da detectabilidade de fato refletem a detectabilidade dos animais (eles não exibem heminegligência, processando os dois estímulos parcialmente), visto que o desvio padrão amostral para a média das detectabilidades na Figura 21 é menor do que 0,7 para todos os pontos.

Os outros resultados obtidos neste experimento não são fundamentalmente diferentes dos resultados obtidos no experimento anterior, mas neste experimento os valores das detectabilidades aumentam e diminuem mais lentamente. Isso pode ser devido à menor pressão seletiva, pois há mais comida e a não-comida tem um valor absoluto menor.

\subsection{Experimento 7}

Como os experimentos 5e 6 envolviam simulações de vida artificial, não sabemos se os resultados são relevantes no estudo da atenção em animais biológicos. Assim, resolvemos testar se seres humanos se comportam de maneira semelhante em uma tarefa análoga em psicofísica. Mais especificamente, resolvemos testar se os seres humanos também adotam a estratégia sub-ótima de prestar menos atenção em estímulos pouco relevantes, mesmo que eles tenham capacidade para tanto e, se caso eles prestassem atenção nos estímulos pouco relevantes, eles teriam um melhor desempenho.

\subsubsection{Métodos}

Os sujeitos de nossos experimentos foram 59 alunos voluntários de graduação ou pós-graduação da USP. 


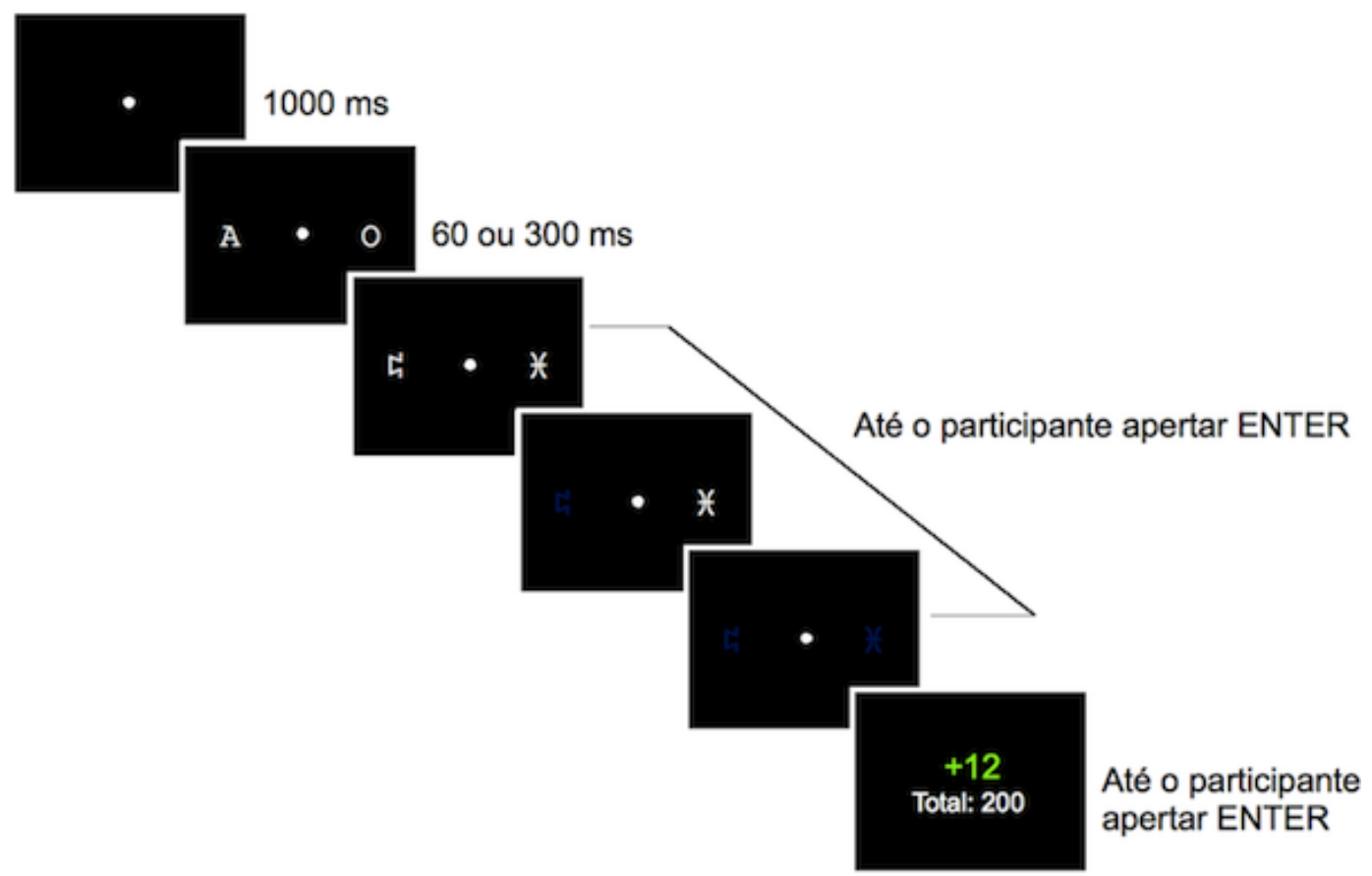

Figura 27 - Esquema temporal de uma apresentação.

Estímulos visuais eram exibidos na tela do computador e em seguida os participantes deveriam emitir uma resposta a estes estímulos usando um teclado.

Cada apresentação de estímulos começava com uma tela escura contendo um ponto branco de fixação no centro (Figura 27). O sujeito deveria manter seu olhar neste ponto, o que foi verificado com uma câmera filmadora. Após 1000 ms, duas letras maiúsculas apareciam na tela, sorteadas entre A, O, U, H, M, S, T, F, X, Z. Cada letra aparecia de um lado da tela, em fonte Courier New na cor branca. As letras permaneciam na tela por um tempo de $60 \mathrm{~ms}$ ou $300 \mathrm{~ms}$. No primeiro bloco, o tempo era de $300 \mathrm{~ms}$, para que o sujeito pudesse treinar, mas a partir do segundo bloco o tempo era de $60 \mathrm{~ms}$. Cada letra era em seguida substituída por um caractere pertencente a alfabetos asiáticos ou árabe. Estes caracteres também apareciam na cor branca, eram escolhidos aleatoriamente para cada apresentação e tinham o papel de "máscara", impedindo que as letras anteriores fossem armazenadas na memória icônica do participante.

A seguir, o participante podia emitir uma resposta, apertando a tecla 1 se ele tinha percebido uma vogal do lado esquerdo da tela e a tecla 3 se ele tinha percebido uma vogal do lado direito da tela. Como podiam aparecer vogais dos dois lados, em apenas um dos lados ou de nenhum dos lados, o participante podia apertar as teclas 1 e 3 para a mesma apresentação, só uma das teclas ou nenhuma delas, caso achasse 
que ambas as letras eram consoantes. O participante apertava ENTER quando tivesse terminado sua resposta.

Toda vez que o participante respondia que havia vogal na tela, ele ganhava ou perdia um valor em pontos. Os pontos que o participante ganhava ou perdia em uma apresentação apareciam então na tela, bem como o valor total que ele tinha obtido até o momento com as apresentações anteriores. Quando o participante apertava ENTER novamente, uma nova apresentação começava. As apresentações estavam distribuídas em dois blocos de treino, que eram os dois primeiros, em que as vogais valiam 6 pontos, e quatro blocos que constituíam no experimento propriamente dito. Todos os blocos eram feitos no mesmo dia, consecutivamente, com um pequeno intervalo entre eles.

\subsubsection{Situação de mesma relevância}

Estes blocos foram os blocos 3 e 4 para metade dos sujeitos e 5 e 6 para a outra metade (os blocos 1 e 2 serviam de treino para ambos os grupos). Neles, as vogais de ambos os lados valiam o mesmo número de pontos (6 pontos).

\subsubsection{Situação de relevâncias diferentes}

Estes blocos foram os blocos 5 e 6 para metade dos sujeitos e 3 e 4 para a outra metade (os blocos 1 e 2 serviam de treino para ambos os grupos). Neles, as vogais de um dos lados, que era o esquerdo para metade dos sujeitos e o direito para a outra metade, valiam mais pontos (11 pontos) do que as vogais do outro lado (1 ponto). $\mathrm{O}$ lado em que as vogais valiam mais pontos nesta situação foi chamado de "lado 1" e o lado em que as vogais valiam menos pontos nesta situação foi chamado de "lado 2".

Os valores de pontos utilizados neste experimento foram os mesmos utilizados no experimento 5 de vida artificial.

\subsubsection{Análise dos dados}

Para o último bloco e meio de cada situação, foi determinado o d' para os lados 1 e 2. O primeiro meio bloco foi descartado, pois era quando os sujeitos descobriam os valores das letras conforme iam assistindo as apresentações. 


\subsubsection{Resultados e Discussão Parcial}

As médias do d' obtidas pelos sujeitos nas diferentes condições do experimento estão mostradas na Figura 28. É possível observar que há uma queda no d' para o lado 2 quando as vogais daquele lado são menos relevantes, como havíamos previsto usando os resultados das simulações, porém esta diferença não foi estatisticamente significativa em seres humanos.

Na Figura 29, podemos observar o desempenho dos sujeitos no lado 2 em função do número total de pontos que eles fizeram. Nesta figura, o d' mostrado corresponde ao d' na situação em que as vogais do lado 2 valem 6 pontos menos o d' na situação em que as vogais do lado 2 valem 1 ponto. De acordo com nossa proposta, este valor deveria ser negativo. De fato, ele é negativo para 58\% dos sujeitos, o que não é estatisticamente significativo. Observando a figura, podemos perceber que os valores de d' para os sujeitos que fizeram menos pontos tendem a ser positivos e os valores de d' para os sujeitos que fizeram mais pontos tendem a ser positivos ou negativos em igual proporção. Estas observações podem indicar a ocorrência de efeito chão e efeito teto: as medidas realizadas não são precisas o suficiente para avaliar sujeitos com desempenho muito ruim ou muito bom. Entre estes dois grupos de sujeitos, há aqueles que fizeram um número intermediário de pontos. Se descartarmos um oitavo da amostra com menos pontos e um oitavo da amostra com mais pontos, $66 \%$ dos sujeitos restantes têm um d' negativo na figura, o que é estatisticamente significativo $(\mathrm{p}=0,02)$. Ainda assim, um número muito grande de sujeitos teve resultado diferente do esperado, o que indica alta flutuação aleatória. 


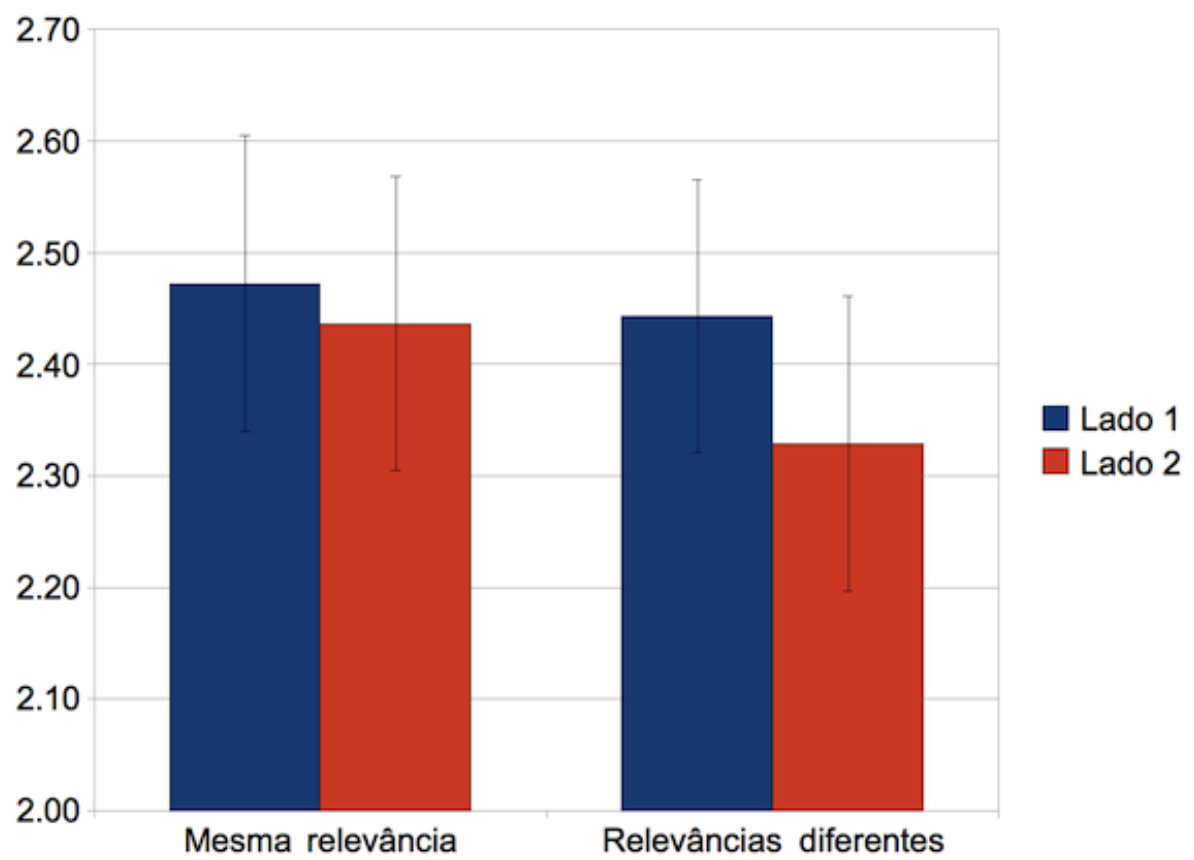

Figura 28 - Resultados do experimento com seres humanos: médias do d' em todas as situações avaliadas.

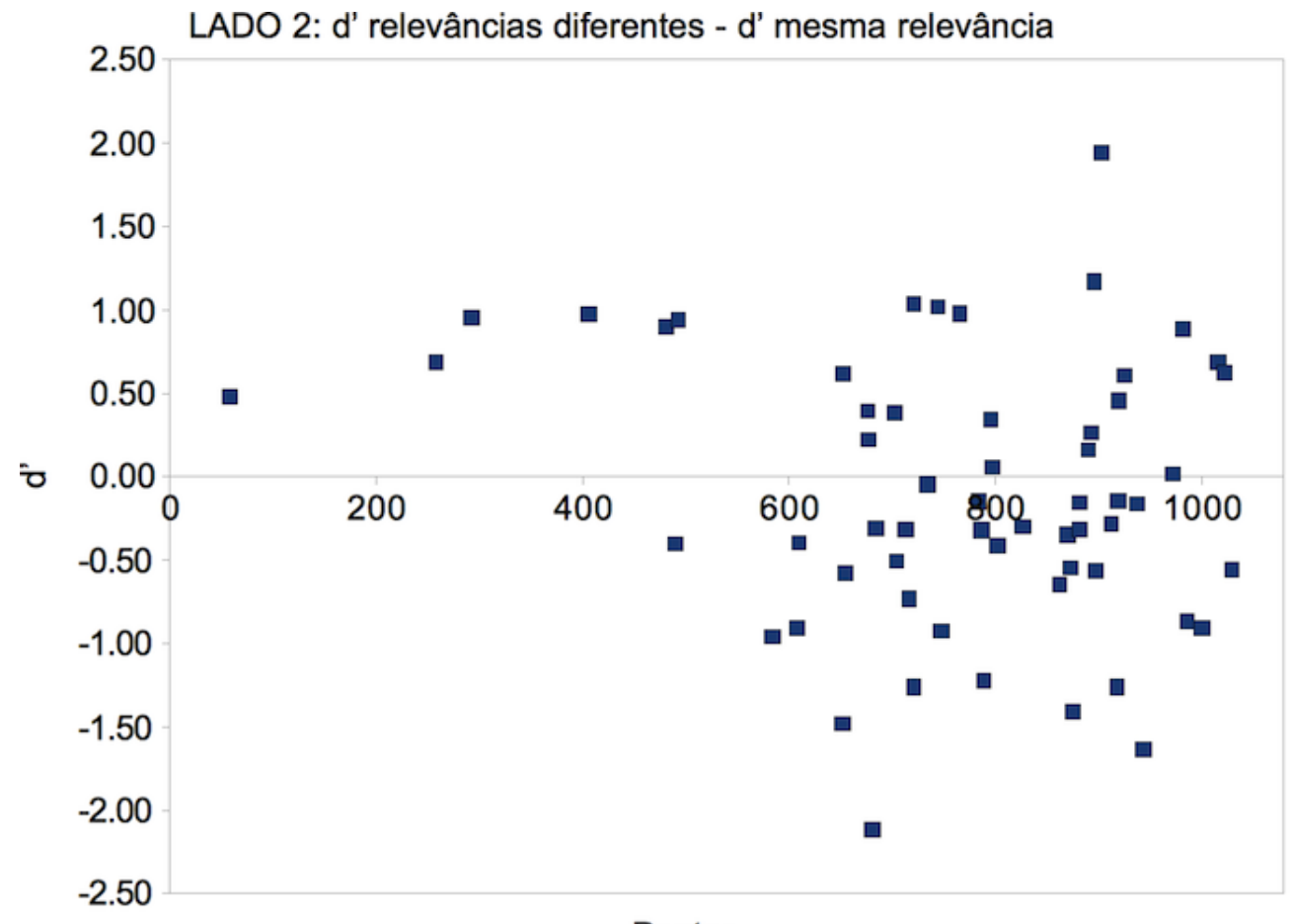

Pontos

Figura 29 - Resultados do experimento com seres humanos: diferença de d' no lado 2 entre as situações de mesma relevância e relevâncias diferentes em função dos pontos ganhos pelos sujeitos. 
Os resultados sugerem que os indivíduos obtêm um pior desempenho quando o estímulo de um lado é menos relevante, ainda que ele tenha a capacidade de obter um alto desempenho dos dois lados, como evidenciado na situação em que os dois estímulos têm a mesma relevância. Porém estes resultados não foram estatisticamente significativos no total da amostra. Só foram significativos para sujeitos com um número de pontos próximo à média.

\subsection{Experimento 8}

Com o experimento 7, mesmo tendo 59 sujeitos, não obtivemos resultados estatisticamente significativos, apesar da tendência observada de acordo com o que era esperado. Decidimos, portanto, empregar experimentos de tempo de reação, ao invés de experimentos de discriminação, para estudar diferenças nos processos cognitivos a estímulos de diferentes relevâncias. Como veremos na seção 6, Tempo de reação e vida artificial, o tempo de reação é uma medida amplamente utilizada no estudo da atenção.

\subsubsection{Métodos}

Os sujeitos de nossos experimentos foram 21 alunos voluntários de graduação da USP.

Cada apresentação de estímulos começava com uma tela escura contendo um ponto branco de fixação no centro. O sujeito devia manter seu olhar neste ponto. Após um tempo aleatório de 500 a 1000 ms, um quadrado aparecia na tela do lado esquerdo ou do lado direito com igual probabilidade. O sujeito deveria emitir uma resposta o mais rapidamente possível, clicando com o botão esquerdo do mouse.

Quando o participante respondia rapidamente ao aparecimento do quadrado, ele ganhava pontos em quantidade dependente do bloco do experimento e da velocidade da resposta. Os pontos que o participante ganhou ou perdeu naquela apresentação apareciam então na tela, bem como o valor total que ele tinha obtido até o momento com as apresentações anteriores. Esta informação era exibida na tela por 1 segundo. As apresentações estavam distribuídas em um bloco de treino de dez apresentações, em que os pontos que o sujeito obtinha não se somavam ao total, e três blocos de cem apresentações que constituíam o experimento propriamente dito. To- 
dos os blocos eram feitos no mesmo dia, consecutivamente, com um pequeno intervalo entre eles.

\subsubsection{Bloco 1}

Neste bloco, os sujeitos ganhavam pontos (P) em função de seu tempo de reação (TR), conforme a equação abaixo.

$$
P=12 e^{-0,008(T R-150)}
$$

Se o sujeito tivesse tempo de reação menor do que $150 \mathrm{~ms}$, a resposta era considerada antecipada (resposta antes de o sujeito ter visto o estímulo) e ele não ganhava nem perdia pontos. Se o sujeito não tivesse respondido em até $1000 \mathrm{~ms}$, a resposta (ou ausência de resposta, no caso) era considerada lenta e ele não ganhava nem perdia pontos.

O objetivo deste bloco era somente determinar o tempo de reação mediano dos sujeitos para ser usado nos blocos seguintes do experimento. Os sujeitos não eram informados disto; só sabiam que os pontos obtidos dependiam da rapidez da resposta.

\subsubsection{Blocos 2 e 3}

Neste bloco, os sujeitos ganhavam pontos de forma "tudo ou nada": se eles respondessem rapidamente ao quadrado, eles ganhavam um número pré-estabelecido de pontos; se eles demorassem para responder ao quadrado, eles não ganhavam nem perdiam pontos. $\mathrm{O}$ limite de velocidade da resposta era a própria mediana do sujeito no bloco 1, mas o sujeito não era informado disto, pois caso contrário ele poderia usar a estratégia de responder mais lentamente aos quadrados no bloco 1. 
Tabela 14 - Pontos que os sujeitos ganhavam de acordo com o tipo de experimento, número do bloco e lado em que o quadrado aparecia.

\begin{tabular}{l|r|r|r|r}
\hline & \multicolumn{2}{|c|}{ Bloco 2 } & \multicolumn{2}{c}{ Bloco 3 } \\
\hline Tipo & Esquerda & Direita & Esquerda & Direita \\
\hline 1 & 6 & 6 & 11 & 1 \\
\hline 2 & 6 & 6 & 1 & 11 \\
\hline 3 & 11 & 1 & 6 & 6 \\
\hline 4 & 1 & 11 & 6 & 6
\end{tabular}

O número de pontos que cada quadrado valia variava com o tipo de experimento (1, 2, 3 e 4), com o bloco (2 e 3) e com o lado em que o quadrado aparecia, de acordo com a Tabela 14. Cinco sujeitos fizeram cada tipo de experimento, exceto o tipo 1, feito por seis sujeitos.

Os valores de pontos utilizados neste experimento foram os mesmos utilizados nos experimentos de vida artificial descritos acima. Para cada bloco, foi determinado o tempo de reação médio e o tempo de reação mediano para cada sujeito.

\subsubsection{Resultados e Discussão Parcial}

Para analisar os resultados, chamamos de "lado 1" o lado esquerdo ou direito em que, para um dado sujeito, o quadrado valia 6 ou 11 pontos dependendo do bloco, e de "lado 2" o lado esquerdo ou direito em que, para um dado sujeito, o quadra-
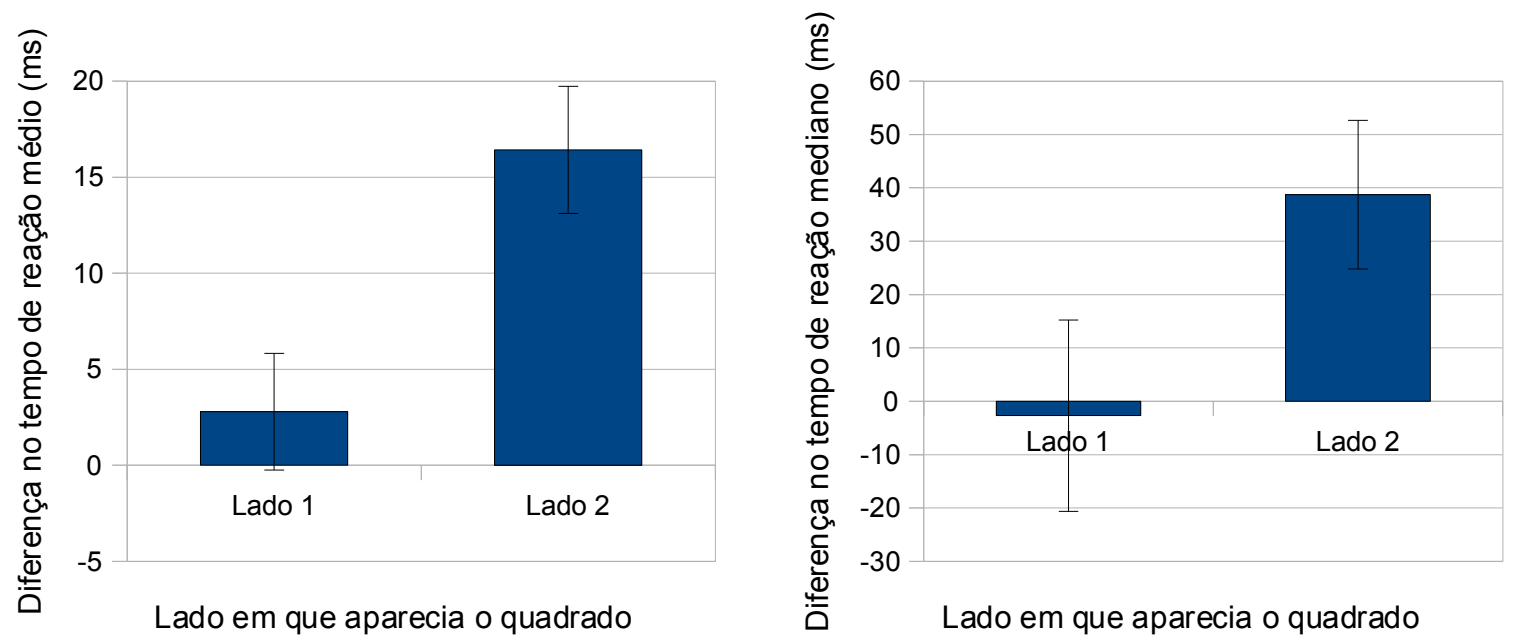

Figura 30 - Diferença no tempo de reação entre o bloco de relevâncias diferentes e o bloco de relevâncias iguais para os dois lados. 
do valia 6 pontos ou 1 ponto dependendo do bloco. Fizemos a diferença nos tempos de reação médio e mediano entre o bloco de relevâncias diferentes e o bloco de relevâncias iguais para os dois lados (Figura 30). Esta diferença não é estatisticamente diferente de zero para o lado 1, tanto para o tempo de reação médio como para o tempo de reação mediano ( $\mathrm{p}>0,3$ para ambos), mas é diferente de zero para o lado 2 ( $\mathrm{p}<0,05$ para ambos), segundo múltiplos testes-t com correção de Bonferroni.

O tempo de reação não mudou para o quadrado do lado 1 quando o valor do quadrado passou de +6 para +11 , mas o tempo de reação aumentou para o quadrado do lado 2 quando o valor do quadrado passou de +6 para +1 . Aqui, os voluntários humanos adotaram a mesma estratégia sub-ótima que os animais artificiais exibiram no experimento 5: eles processam o estímulo que vale menos com menos eficiência quando as relevâncias são diferentes, sem que isso gere um benefício no processamento do estímulo que vale mais. Eles podem alocar mais recursos atencionais para processar os estímulos mais relevantes do que os estímulos menos relevantes, mas como não é a limitação destes recursos que determina o desempenho dos sujeitos (o gargalo está em outro local; no sistema sensorial ou na resposta motora, por exemplo), esta alocação de recursos não gera nenhuma vantagem para os estímulos mais relevantes.

\subsection{Discussão parcial da seção 5}

Os nossos experimentos, baseados em redes neurais evoluindo darwiniamente (experimentos 5 e 6), sugerem que a alocação da atenção, inferida a partir de medidas de detectabilidade para o animal, não é decorrente de limitações na capacidade de processamento, mas, na verdade, da relevância adaptativa relativa dos estímulos frente à ação a ser emitida. Os resultados psicofísicos, baseados em medidas de detectabilidade e tempo de reação, também apontam para a relevância do estímulo - e não para a capacidade limitada do sistema nervoso - como fator determinante da alocação da atenção.

Não só em animais artificiais mas também em seres humanos, os estímulos mais relevantes atraem mais a atenção do que estímulos menos relevantes, mesmo que esta estratégia muitas vezes gere uma desvantagem. Nos experimentos com animais artificiais, não existe pressão seletiva para fazer com que os animais processem estímulos pouco relevantes. Nos experimentos com seres humanos, não existe motivação 
suficiente para que os sujeitos respondam rapidamente a um estímulo que vale somente 1 ponto, quando comparado ao estímulo do outro lado, que vale 11 pontos. 


\section{TEMPO DE REAÇÃO E VIDA ARTIFICIAL}

\subsection{Introdução}

Para testar quais fatores influenciam a evolução do tempo de reação, entre os fatores discutidos na introdução (limitação de recursos, presença de ruído e seleção da ação), fizemos experimentos de vida artificial em que os animais artificiais evoluíam em função de seu desempenho em uma tarefa de tempo de reação.

A Tabela 15 descreve os experimentos desta seção de forma resumida.

Tabela 15 - Experimentos de tempo de reação. São dados o número do experimento, a página em que ele é descrito em detalhes, o tipo do experimento (tempo de reação simples ou tempo de reação de escolha), a proporção entre pistas válidas, neutras e inválidas, o número de gerações total, o desvio padrão do ruído e se o tempo de reação obtido para pistas válidas foi menor do que o tempo de reação obtido para pistas neutras, como observado em seres humanos.

\begin{tabular}{|l|l|l|l|l|l|l}
\hline Número & Página & $\begin{array}{c}\text { Experimento de } \\
\text { tempo de reação }\end{array}$ & $\begin{array}{c}\text { Proporção } \\
\text { entre pistas }\end{array}$ & Gerações & Ruído & $\begin{array}{l}\text { TR válida < } \\
\text { TR neutra? }\end{array}$ \\
\hline 9 & 87 & simples & $8: 5: 2$ & 150 & 0 & não \\
\hline 10 & 91 & simples & $8: 5: 2$ & 30 & 0 & sim \\
\hline 11 & 93 & simples & $8: 15: 2$ & 30 & 0 & não \\
\hline 12 & 95 & simples & $8: 15: 2$ & 150 & 2 & não \\
\hline 13 & 97 & escolha & $8: 15: 2$ & 30 & 0 & não \\
\hline 14 & 98 & escolha & $8: 15: 2$ & 150 & variável & variável \\
\hline 15 & 102 & escolha & $8: 8: 2$ & 150 & 2 & sim \\
\hline 16 & 102 & escolha & $8: 2: 2$ & 150 & 2 & sim \\
\hline 17 & 104 & escolha & $8: 15: 2$ & 150 & 2 & sim \\
\hline
\end{tabular}

\subsection{Experimento 9}

Este experimento de vida artificial é um experimento de tempo de reação simples conforme discutido na introdução e é a base para os experimentos subsequentes. 


\subsubsection{Métodos}

Os animais eram dotados de uma rede neural com seis neurônios, na qual todos os neurônios eram conectados a todos os outros neurônios, inclusive a si mesmos (Figura 31). O modelo de neurônio utilizado neste experimento, assim como em todos os experimentos de tipo de reação descritos abaixo, foi o "integra e dispara", pois ele nos permite medir o tempo de reação, ao contrário do perceptron. Dos seis neurônios que o animal possuía, cinco eram neurônios de entrada, que sinalizavam o aparecimento da pista e do alvo, e o sexto neurônio era de saída, sinalizando a resposta do animal.

O animal participa de um experimento de tempo de reação simples durante sua vida, cujas apresentações estão descritas abaixo.

1. Os neurônios são retornados à sua condição inicial: o potencial de membrana ao potencial de repouso e o nível de estimulação ao viés.

2. O animal não recebe nenhum estímulo por 50 unidades de tempo.

3. O animal recebe uma pista, que pode ser neutra ou indicar o lado esquerdo ou direito, por um intervalo de duração aleatória com distribuição uniforme que vai de 100 a 200 unidades de tempo.

4. Um estímulo alvo é apresentado em um dos lados e o animal deve responder a ele o mais rapidamente possível.

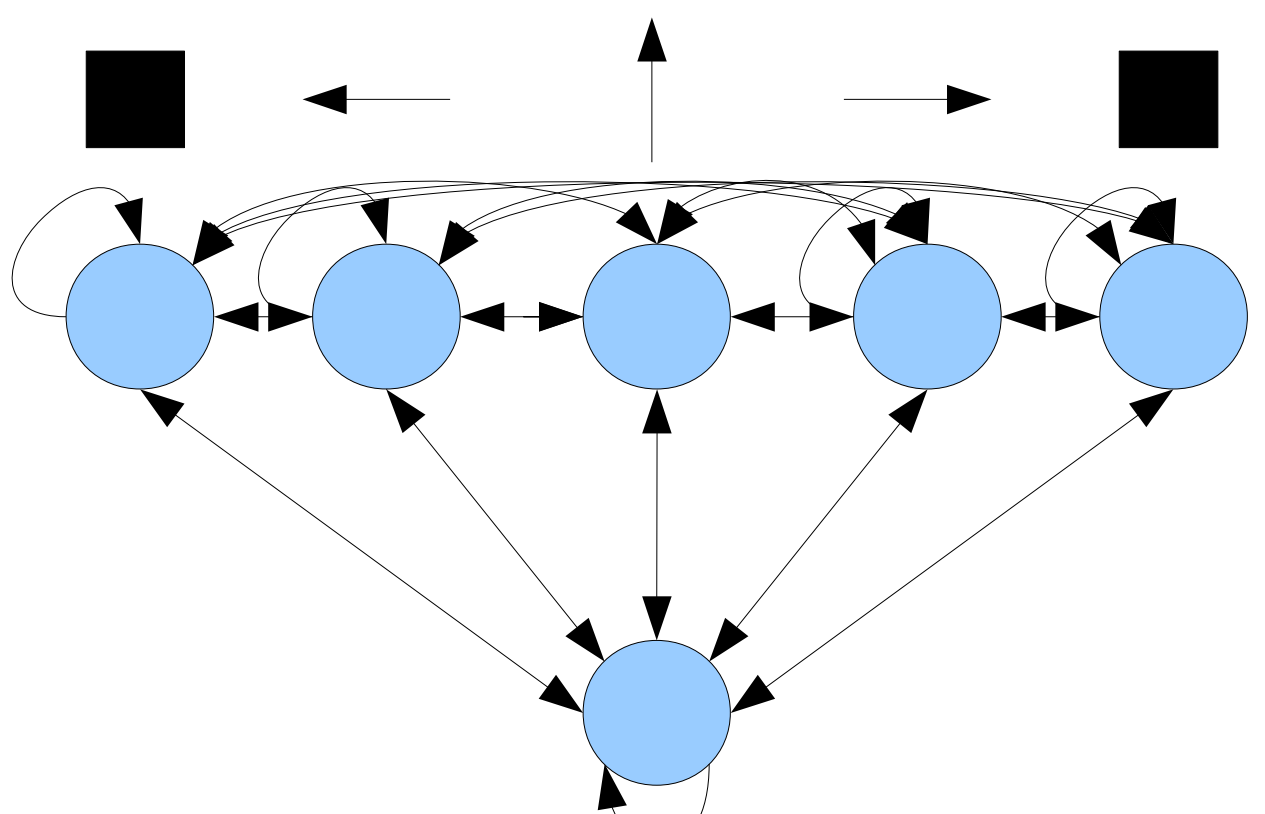

Figura 31 - Rede neural utilizada nos experimentos de tempo de reação simples. 
Quando a pista está presente, o neurônio correspondente à pista esquerda, neutra ou direita da rede neural (Figura 31) é estimulado por uma corrente de intensidade +5 . Da mesma forma, quando o alvo está presente, o neurônio correspondente ao alvo esquerdo ou direito da rede neural é estimulado por uma corrente de intensidade +5 . Não existe resposta certa ou errada - a tarefa do animal é simplesmente responder ao alvo o mais rapidamente possível. Se o animal não responder em até 1000 unidades de tempo após o aparecimento do alvo, o valor adaptativo não é alterado. Se o animal responder ao alvo, o valor adaptativo é alterado conforme a equação abaixo, que é uma função do tempo de reação (rt):

$$
f(r t)=\left\{\begin{array}{l}
0, \text { se } r t<0 \\
1000 \exp (-0,01 r t), \text { se } r t \geq 0
\end{array}\right.
$$

Quando o animal responde ao alvo antes do aparecimento deste $(\mathrm{rt}<0)$, a resposta é dita antecipada e o animal não ganha pontos. Quando o animal não responde ao alvo em até 1000 unidades de tempo, a resposta (neste caso, ausência de resposta) é dita lenta.

A proporção entre pistas válidas, neutras e inválidas é de 8:5:2, próxima das proporções utilizadas na maioria dos experimentos de tempo de reação deste tipo (por exemplo, POSNER, 1980). O alvo aparece o mesmo número de vezes à direita e à esquerda da tela. O número de apresentações nas quais um animal participa durante a sua vida é 60, com tipos de apresentação conforme a Tabela 16. As apresentações são apresentadas em ordem aleatória.

Para cada animal, são armazenados os tempos de reação medianos para pistas válidas, neutras e inválidas, o número de respostas lentas e o número de respostas antecipadas.

Tabela 16 - Tipos de apresentação no experimento 9.

\begin{tabular}{l|l|r}
\hline \multicolumn{1}{c|}{ Pista } & \multicolumn{1}{|c|}{ Posição do alvo } & Número de apresentações \\
\hline Válida & Direita & 18 \\
\hline Válida & Esquerda & 16 \\
\hline Neutra & Direita & 10 \\
\hline Neutra & Esquerda & 10 \\
\hline Inválida & Direita & 4 \\
\hline Inválida & Esquerda & 4 \\
\hline
\end{tabular}


Cada simulação contém cinco populações de vinte indivíduos cada. As populações evoluem por 150 gerações, a seleção é feita por torneio de duplas, há migração a cada 5 gerações, a probabilidade de mutação é 5\% e consiste na adição ao valor do gene de um número aleatório entre -0,2 e 0,2 com distribuição uniforme. Os genes representam os pesos sinápticos e os vieses da rede neural.

Em relação aos fatores citados acima que podem dar origem ao fenômeno estudado, vejamos como cada um deles afeta este experimento:

1. Limitação de recursos: como os animais só possuem seis neurônios, todos eles necessários para a tarefa, não é possível que haja uma limitação de recursos maior do que esta.

2. Presença de ruído: não há ruído no ambiente nem na rede neural.

3. Seleção da ação: como só há uma ação possível, não há necessidade de uma ação apropriada ser selecionada dentre duas ou mais opções.

\subsubsection{Resultados e Discussão Parcial}

Após 150 gerações, considerando os números medianos da simulação, os tempos de reação para qualquer tipo de pista foram de 1 unidade de tempo e os números de respostas lentas e antecipadas foram, ambos, igual a zero. Os animais obtiveram um desempenho perfeito no experimento de tempo de reação simples, sem erros e com a resposta mais rápida ao alvo possível.

Após 150 gerações, não há diferença no tempo de reação do animal a pistas válidas, inválidas e neutras, pois o tempo de reação é o menor possível. A noção de limitação de recursos não é um conceito útil para entender o resultado deste experimento, pois a rede neural do animal é a menor possível e o desempenho do animal é o melhor possível.

O sinal para que a rede neural emita a sua resposta é inequívoco, pois não há ruído, e só há uma resposta possível a cada estímulo. Uma resposta imediata pode ser obtida simplesmente ao conectar os neurônios que são estimulados pelos alvos ao neurônio de resposta com um peso sináptico suficientemente grande para estimular o neurônio de resposta acima do limiar já na próxima unidade de tempo. A informação fornecida pela pista pode ser completamente ignorada. Assim, podemos entender como obtivemos um resultado deste tipo. Porém, mesmo nesta situação, o resultado 
seria diferente se interrompêssemos a simulação no meio, pois certamente existe um período anterior àquele em que as redes neurais ficaram inteiramente otimizadas.

\subsection{Experimento 10}

Por conta do resultado do experimento 9, o experimento 10 foi realizado seguindo os mesmos métodos do experimento 9, mas interrompendo as simulações na geração 30 ao invés de ir até a geração 150. Nesta geração, os tempos de reação medianos em uma simulação já são muito baixos, mas em geral não atingiram o valor mínimo (1 unidade de tempo). Assim, foi possível comparar o comportamento do animal aos diferentes tipos de pista.

\subsubsection{Métodos}

Iguais aos do experimento 9, mas interrompendo as simulações na geração 30. Esta simulação foi replicada 200 vezes por conta da alta variabilidade nos resultados.

\subsubsection{Resultados e Discussão Parcial}

Os resultados são mostrados na Figura 32.
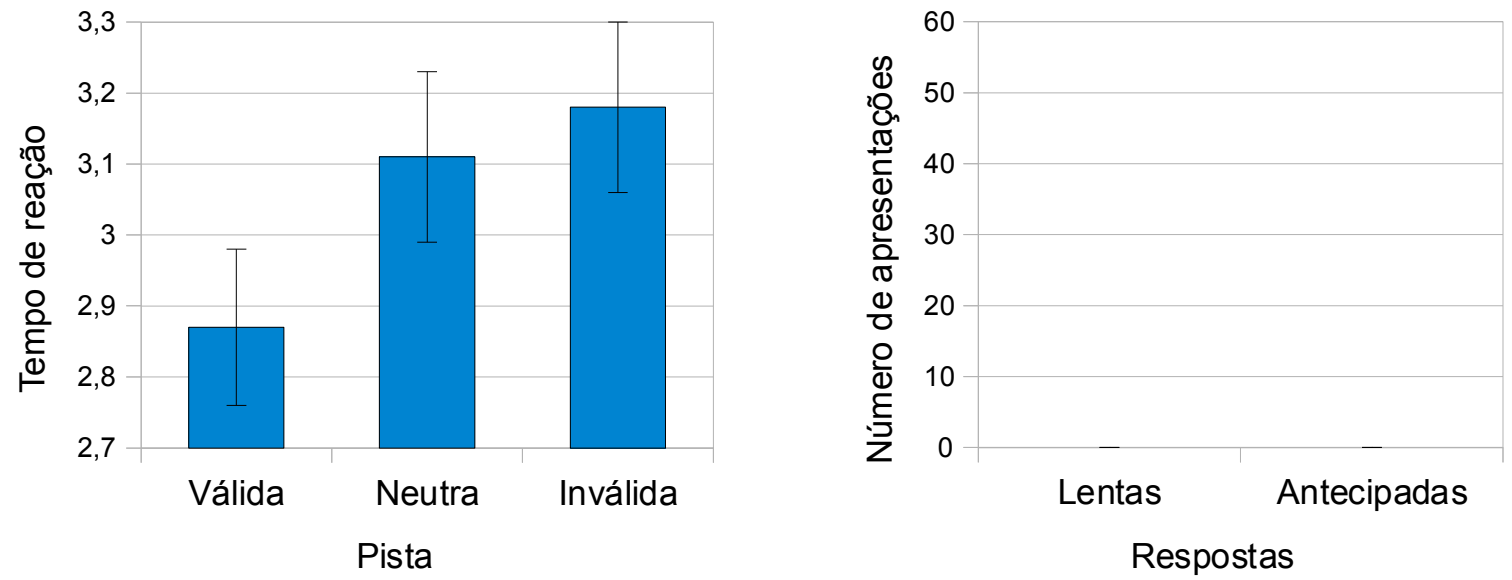

Figura 32 - Tempo de reação médio e número médio de respostas lentas e antecipadas para o experimento 10 .

Os resultados obtidos neste experimento para tempo de reação em função do tipo de pista obedecem a um padrão semelhante aos resultados obtidos com seres 
humanos em uma tarefa de tempo de reação simples. A pista válida gera o menor tempo de reação e a pista inválida, o maior tempo de reação. A pista neutra gera um valor intermediário de tempo de reação.

Este resultado pode indicar que o modo pelo qual as redes neurais dos animais processam os estímulos sensoriais é semelhante ao modo pelo qual os seres humanos processam os estímulos sensoriais nestes experimentos, ou seja, este experimento pode ter capturado uma característica em comum com o processamento neural em seres humanos. A pista válida pode estar fornecendo ao animal algum tipo de informação que facilita o modo como a rede processa estímulos e gera sua resposta.

Essa explicação não parece provável à luz da discussão do experimento anteri or, em que vimos que a informação fornecida pela pista não é necessária nestas condições simples. Há, no entanto, uma explicação alternativa para os resultados obtidos. Primeiro, vamos observar que as barras para cada tipo de pista no gráfico de tempo de reação da Figura 32, repetido abaixo na Figura 33, têm alturas relativas na ordem inversa das barras no gráfico de frequência das pistas na Figura 33, ou seja, a menor barra em um gráfico é a maior barra no outro e assim por diante. O tempo de reação para pistas válidas é o menor e há mais pistas válidas do que pistas neutras e pistas inválidas (somadas, inclusive). O tempo de reação para pistas inválidas é o maior e as pistas inválidas também são as menos frequentes no experimento. Notamos que as apresentações em que a pista é válida contribuem mais do que as outras apresentações para o valor adaptativo e as apresentações em que a pista é inválida contribuem menos do que as outras apresentações. Desta forma, os animais que estão
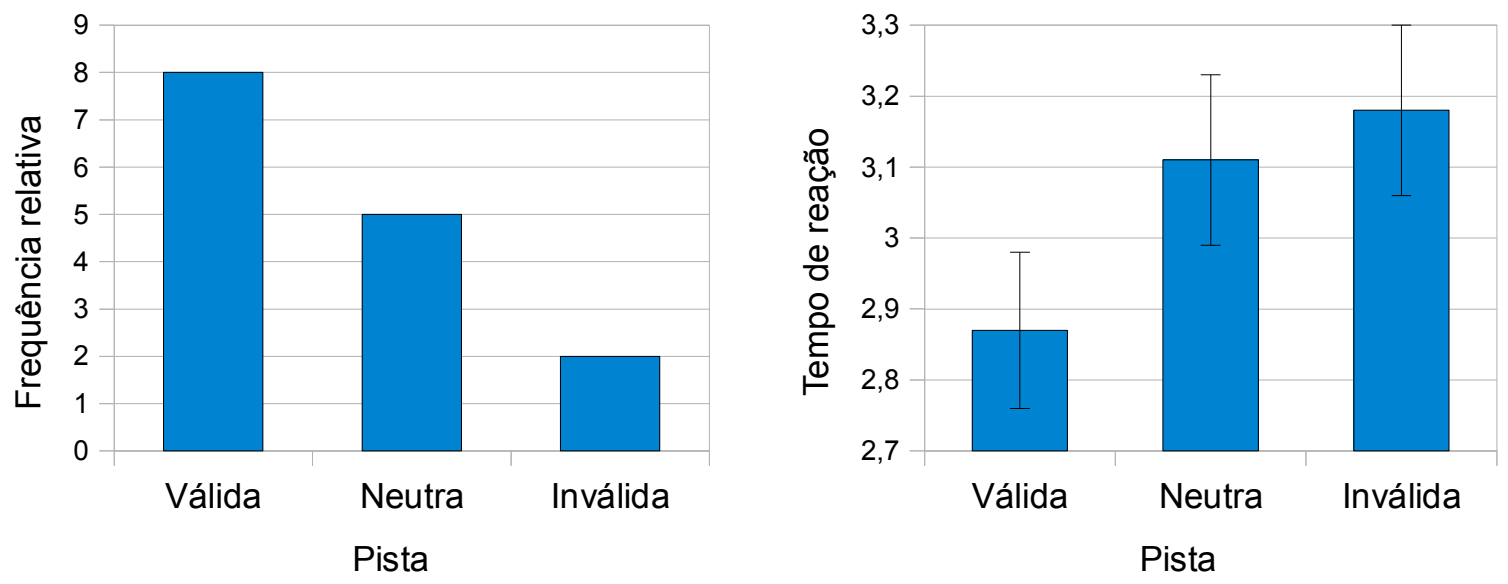

Figura 33 - Frequências relativas dos tipos de pista (8:5:2) e tempo de reação médio para o experimento 10. 
melhor adaptados à pista válida tenderão a ter um valor adaptativo maior, não necessariamente porque a pista fornece uma informação a respeito do local de aparecimento do alvo, mas simplesmente porque ela é mais frequente do que as outras pistas. Chamaremos de "efeito da frequência" esta vantagem de um tipo de pista em relação a outro que nada depende da informação fornecida sobre a posição do alvo, mas é somente uma função das frequências relativas.

Se esse efeito for a causa dos resultados observados neste experimento, então, em uma simulação em que a pista neutra é a mais frequente, espera-se que os animais tenham o tempo de reação menor para a pista neutra e não para a pista válida. Se a pista válida diminui o tempo de reação porque fornece uma informação importante ao animal e não pelo efeito da frequência, então o tempo de reação para a pista válida continuará sendo o menor, ainda que a pista válida não seja a mais frequente.

\subsection{Experimento 11}

Neste experimento, o objetivo foi averiguar o que acontece quando a pista neutra, não a pista válida, é a mais frequente.

\subsubsection{Métodos}

Iguais aos do experimento anterior, mas agora a proporção de pistas válidas, neutras e inválidas é 8:15:2. Cada animal participa de 50 apresentações durante sua vida, metade do que é mostrado na Tabela 17.

Tabela 17: Tipos de apresentação no experimento 11.

\begin{tabular}{l|l|r}
\hline \multicolumn{1}{c|}{ Pista } & \multicolumn{1}{|c|}{ Posição do alvo } & Número de apresentações \\
\hline Válida & Direita & 16 \\
\hline Válida & Esquerda & 16 \\
\hline Neutra & Direita & 30 \\
\hline Neutra & Esquerda & 30 \\
\hline Inválida & Direita & 4 \\
\hline Inválida & Esquerda & 4 \\
\hline
\end{tabular}


Foram realizadas 200 simulações, por conta da alta variabilidade nos resultados, só até a geração 30, para manter os tempos de reação acima do valor mínimo e para que possamos ver diferenças entre os tempos de reação aos diversos tipos de pista.

\subsubsection{Resultados e Discussão Parcial}

Os resultados do experimento 11 estão mostrados na Figura 34.
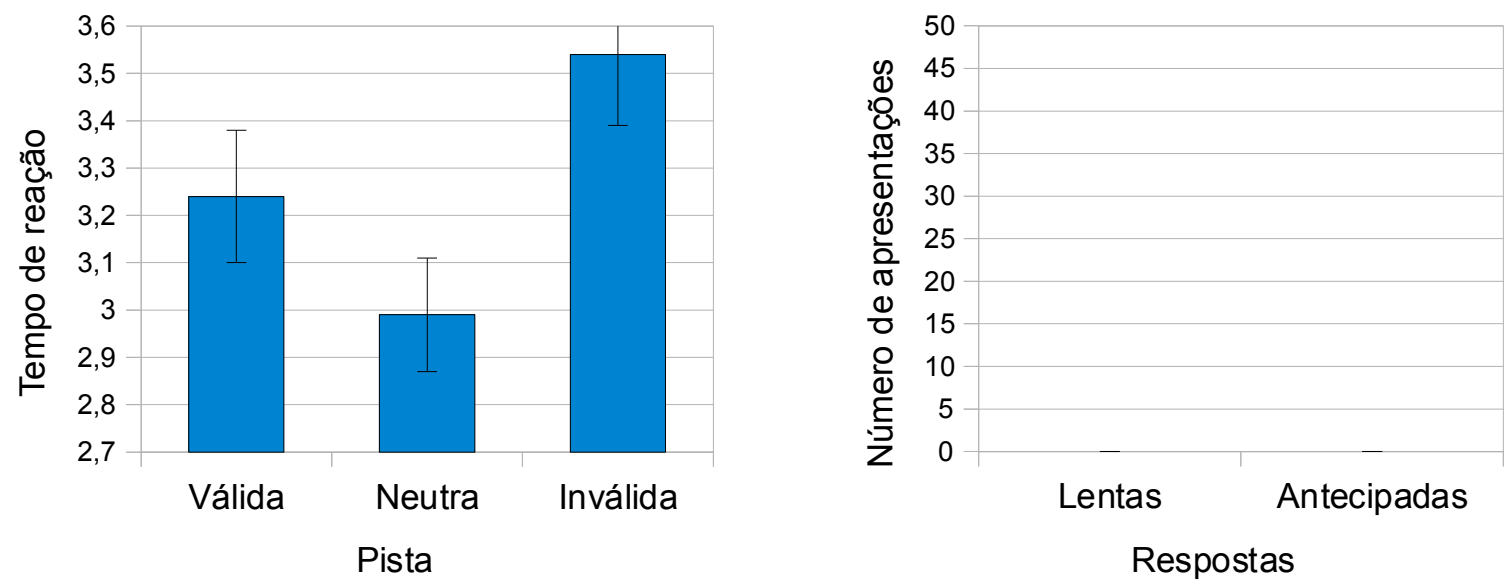

Figura 34 - Resultados do experimento 11.

O resultado do experimento 11 reflete a frequência dos tipos de pistas, conforme mostrado na Figura 35. Podemos então concluir que a informação dada pela pista quanto à localização do alvo não é o fator mais importante para a determinação dos
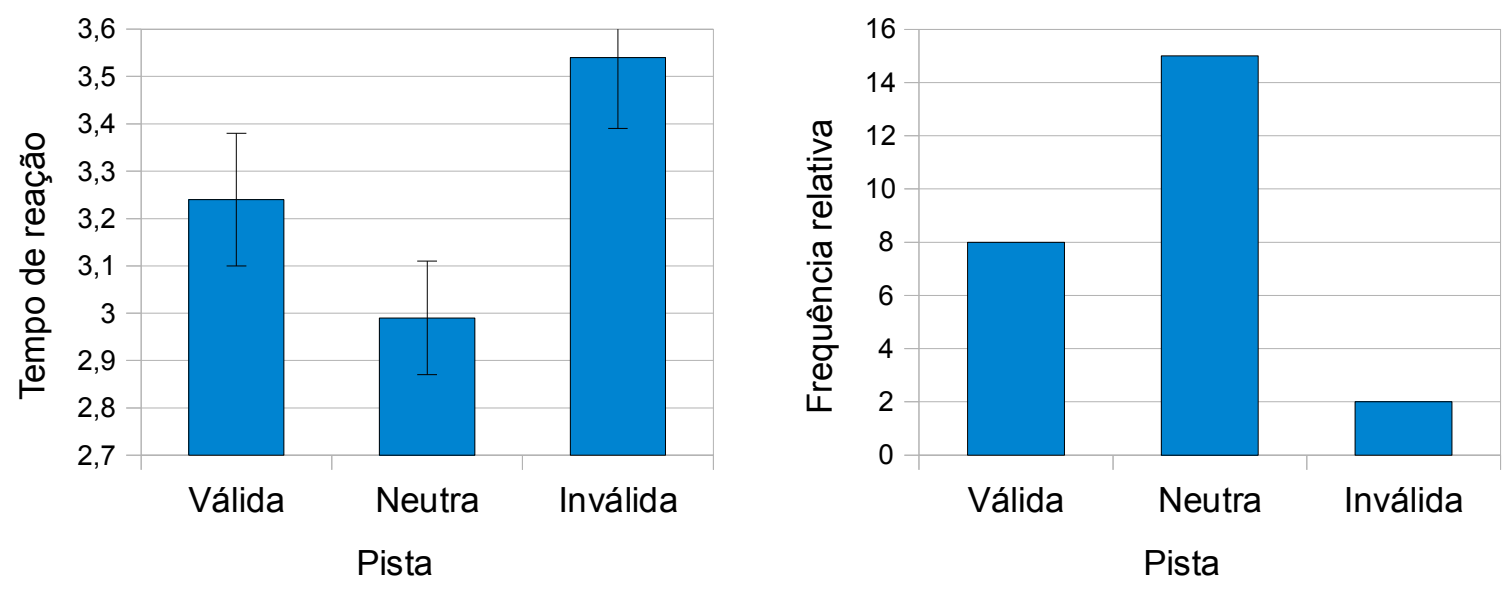

Figura 35 - Frequências relativas dos tipos de pista (8:5:2) e tempo de reação médio para o experimento 11. 
tempos de reação nos experimentos 10 e 11. Os animais obtiveram o menor tempo de reação para a pista mais frequente, quer ela seja informativa (pista válida, pelo experimento 10) ou não (pista neutra, pelo experimento 11). Pelo efeito da frequência, então, o animal tem uma tendência a responder mais rapidamente à pista mais frequente, pois ela contribui mais que as outras pistas para o valor adaptativo. Como queremos obter um modelo em que os animais utilizam as informações fornecidas pelas pistas e por isso obtêm menor tempo de reação a pistas válidas do que a pistas neutras, temos que garantir que os resultados obtidos não são devidos ao efeito da frequência. Assim, nos experimentos seguintes, o número de pistas neutras será sempre maior ou igual ao número de pistas válidas. Aí, então, teremos certeza de que qualquer resultado favorável não se deve ao efeito da frequência.

\subsection{Experimento 12}

Neste experimento, acrescentamos ruído às redes neurais do experimento 11, no qual a pista neutra é a mais frequente. É possível que a adição de ruído à rede neural dê uma vantagem evolutiva ao animal que utiliza a informação espacial dada pela pista válida e assim tenha um tempo de reação menor para a pista válida do que para a pista neutra.

\subsubsection{Métodos}

Iguais aos do experimento anterior com o acréscimo de ruído. O ruído é somado ao nível de estimulação de cada neurônio a cada instante de tempo. Ele é um número aleatório com distribuição normal, média 0 e desvio padrão 2. Quarenta repetições desta simulação foram feitas. 


\subsubsection{Resultados e Discussão Parcial}

Os resultados para 40 replicações deste experimento para a geração 150 são mostrados na Figura 36.

Os tempos de reação obtidos para a geração 150 deste experimento são muito maiores do que aqueles obtidos para a geração 30 dos experimentos anteriores. Os valores observados aqui são cerca de 10 vezes os valores obtidos anteriormente. Quando comparamos estes resultados aos da geração 150 dos experimentos anteriores, a diferença nos tempos de reação é maior ainda, pois neste ponto da simulação os animais dos experimentos anteriores já estavam respondendo ao alvo no tempo mínimo possível. O número de respostas antecipadas também é maior - 0 nos experimentos anteriores e 5,93 $\pm 0,14$ neste experimento. Todas estas diferenças nos resultados decorrem da adição de ruído ao experimento, pois é neste aspecto que os métodos empregados aqui diferem dos método dos experimentos anteriores. Este experimento sugere que a presença de ruído, e com ela a necessidade de ser capaz de distinguir entre sinal e ruído, retarda a geração de uma resposta e aumenta a probabilidade de erros.

Também se nota o efeito da frequência: como o número de pistas neutras é maior do que o número de pistas válidas, os animais têm o menor tempo de reação para pistas neutras. Não há evidências de que estes animais estejam utilizando a informação espacial fornecida pela pista válida, o que difere do que é observado com seres humanos.
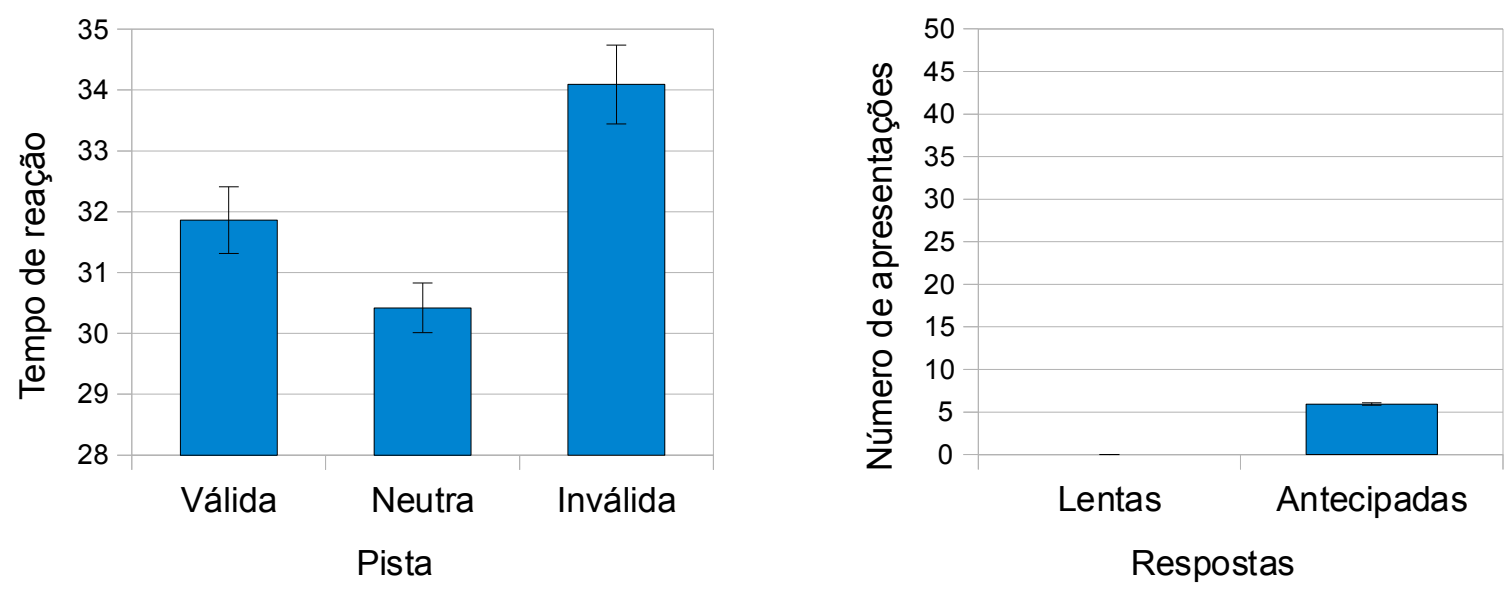

Figura 36 - Resultados do experimento 13. 


\subsection{Experimento 13}

Como a adição de ruído a um experimento de tempo de reação simples não resultou em um comportamento semelhante ao dos seres humanos, que têm um tempo de reação menor para a pista válida ainda que a pista neutra seja a mais frequente, resolvemos testar a evolução de animais artificiais para fazer uma tarefa de tempo de reação de escolha ao invés de tempo de reação simples. Esta mudança adiciona à simulação o fator de seleção da ação.

\subsubsection{Métodos}

Os métodos diferem do métodos empregado nos experimentos anteriores, já que a rede neural dos animais tem, aqui, um neurônio de saída a mais, conforme, mostrado na Figura 37, e os animais devem responder ao alvo à esquerda com um determinado neurônio de saída e ao alvo à direita com o outro neurônio de saída. Se os animais emitem uma resposta com o neurônio errado, eles não ganham pontos naquela apresentação. Não há ruído e a simulação foi repetida 40 vezes.

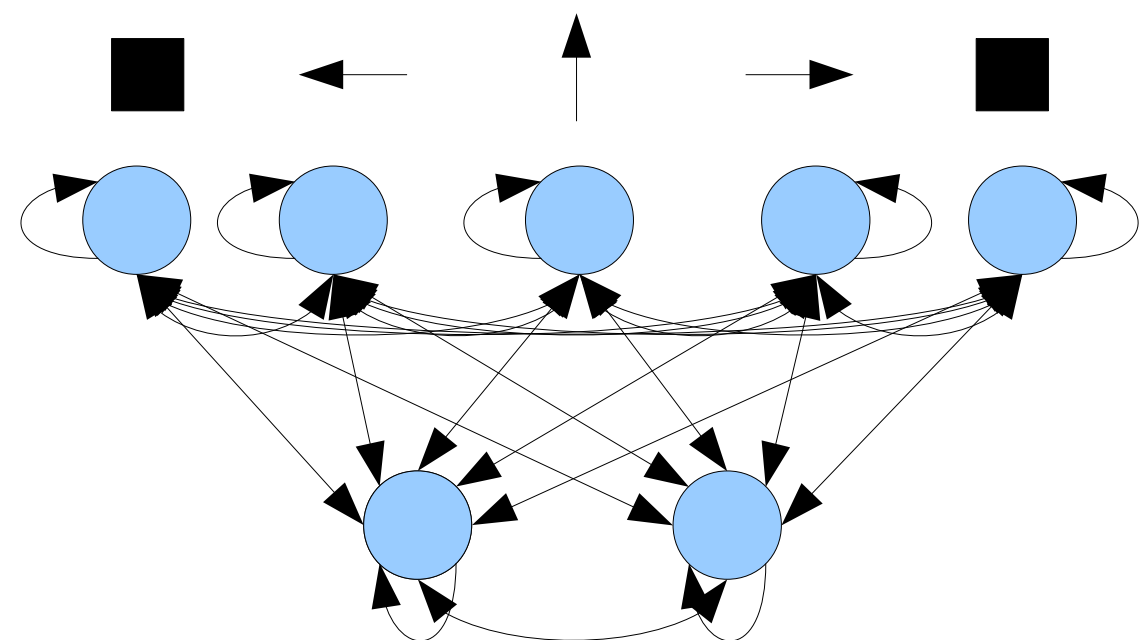

Figura 37 - Rede neural utilizada nos experimentos com tempo de reação de escolha. 


\subsubsection{Resultados e Discussão Parcial}

Os resultados das simulações na geração 30 são mostrados na Figura 38.
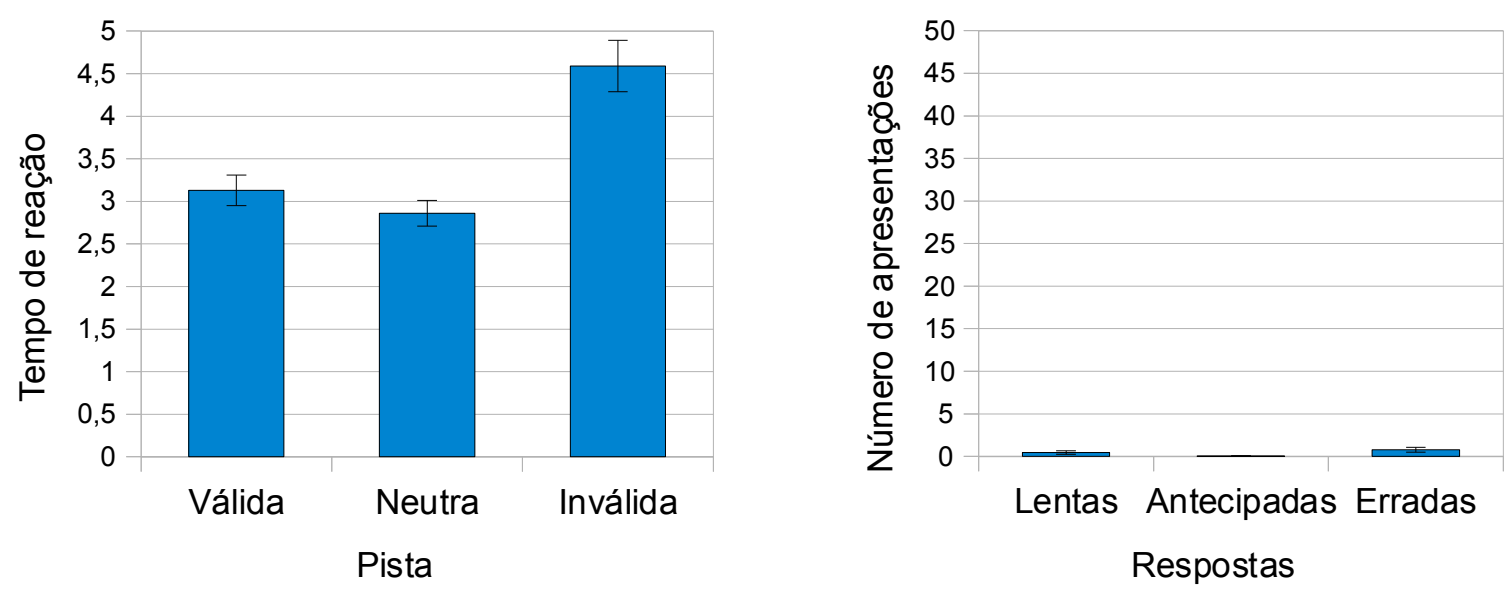

Figura 38 - Resultados do experimento 13.

Quando a tarefa é de tempo de reação de escolha e não há ruído, o padrão dos resultados é igual aos dos outros experimentos sem ruído - o animal atinge um tempo de reação muito baixo logo no início da simulação e tem menor tempo de reação para a pista mais frequente (neste caso, a neutra).

\subsection{Experimento 14}

No experimento 14, resolvemos testar o que acontece quando níveis diferentes de ruído, dados pelo desvio padrão da distribuição normal de média 0, eram adicionados ao experimento de tempo de reação de escolha.

\subsubsection{Métodos}

Exceto pelo nível variável de ruído $(0,25 ; 0,5 ; 1 ; 2 ; 4$ ou 8$)$, as simulações eram idênticas às do experimento anterior, ou seja, era um experimento de tempo de reação de escolha em que a proporção entre as pistas válidas, neutras e inválidas era 8:15:2. Quarenta repetições desta simulação foram feitas para cada nível de ruído. 


\subsubsection{Resultados e Discussão Parcial}

Os resultados deste experimento são mostrados na Figura 39 e na Figura 40. A diferença entre os tempos de reação para as pistas neutras e as válidas só é estatistica mente significativa $(\mathrm{p}<0,05)$ por dois testes-t pareados com correção de Bonferroni) quando o desvio padrão do ruído era 2 ou 4. 


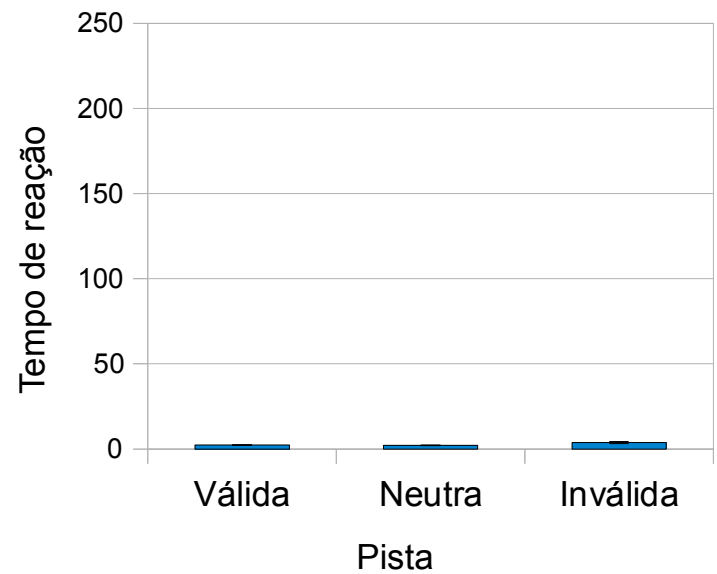

Ruído 0,25

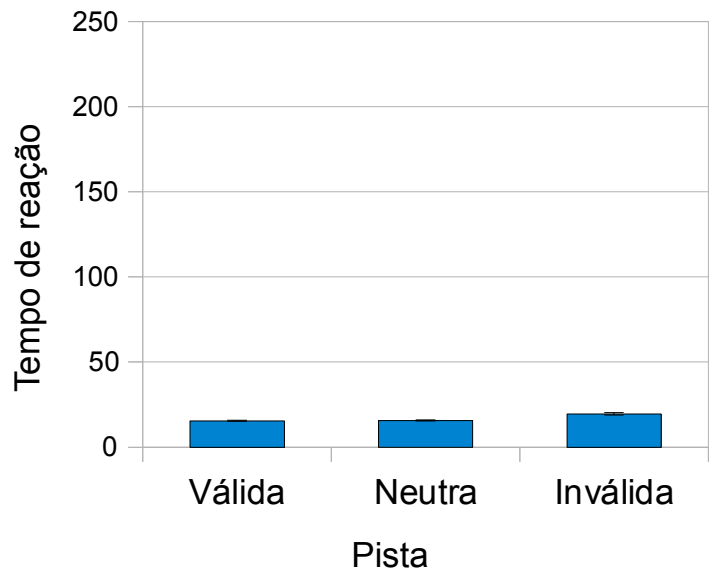

Ruído 1

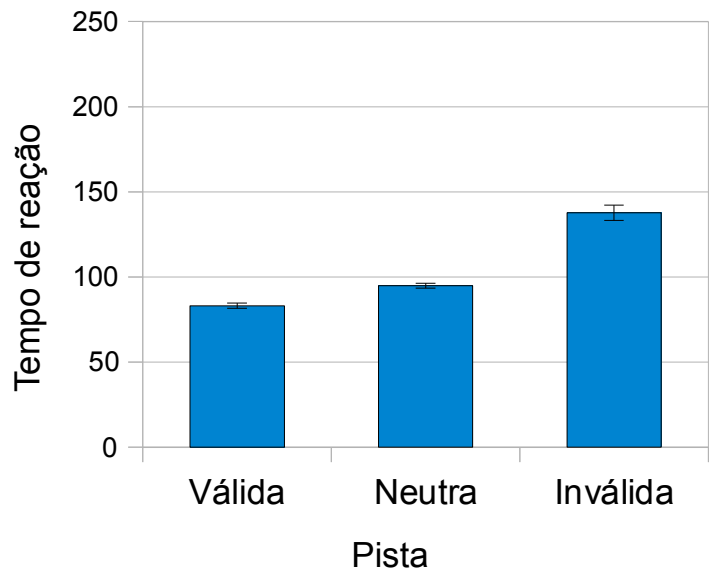

Ruído 4

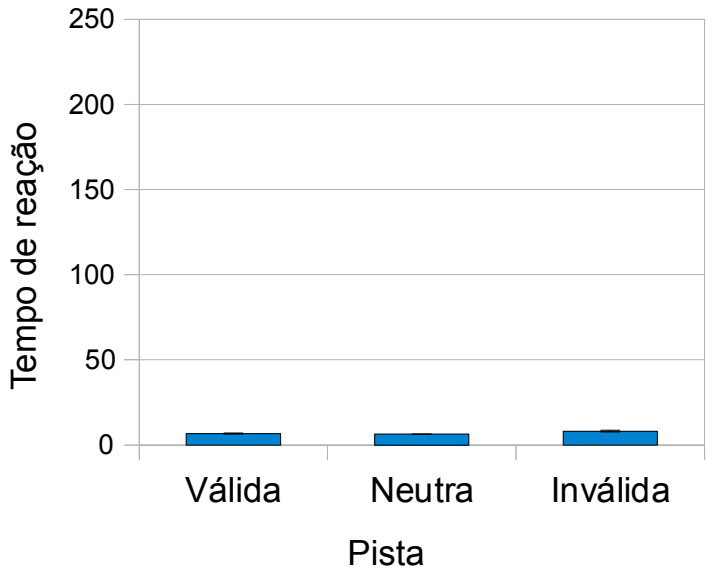

Ruído 0,5

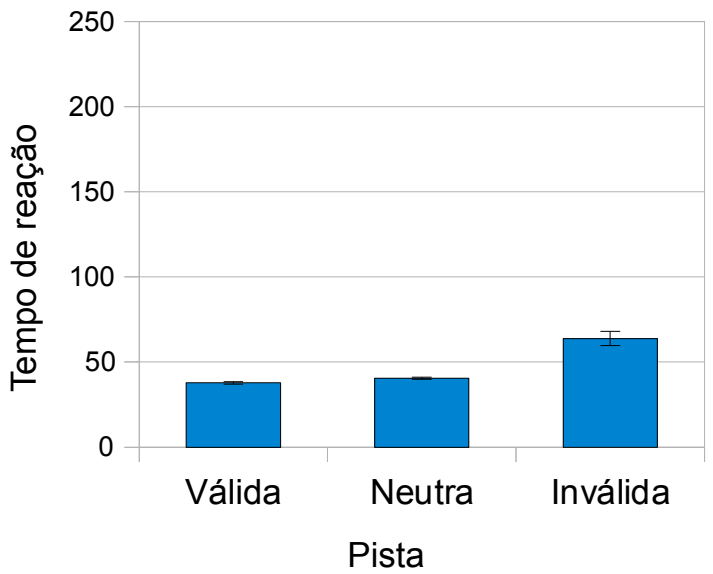

Ruído 2

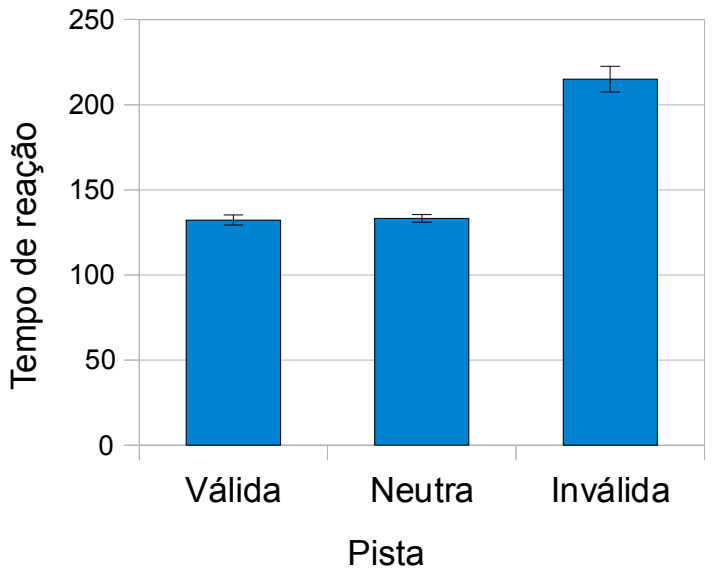

Ruído 8

Figura 39 - Resultados obtidos no experimento 14: tempo de reação para pistas válidas, neutras e inválidas. 


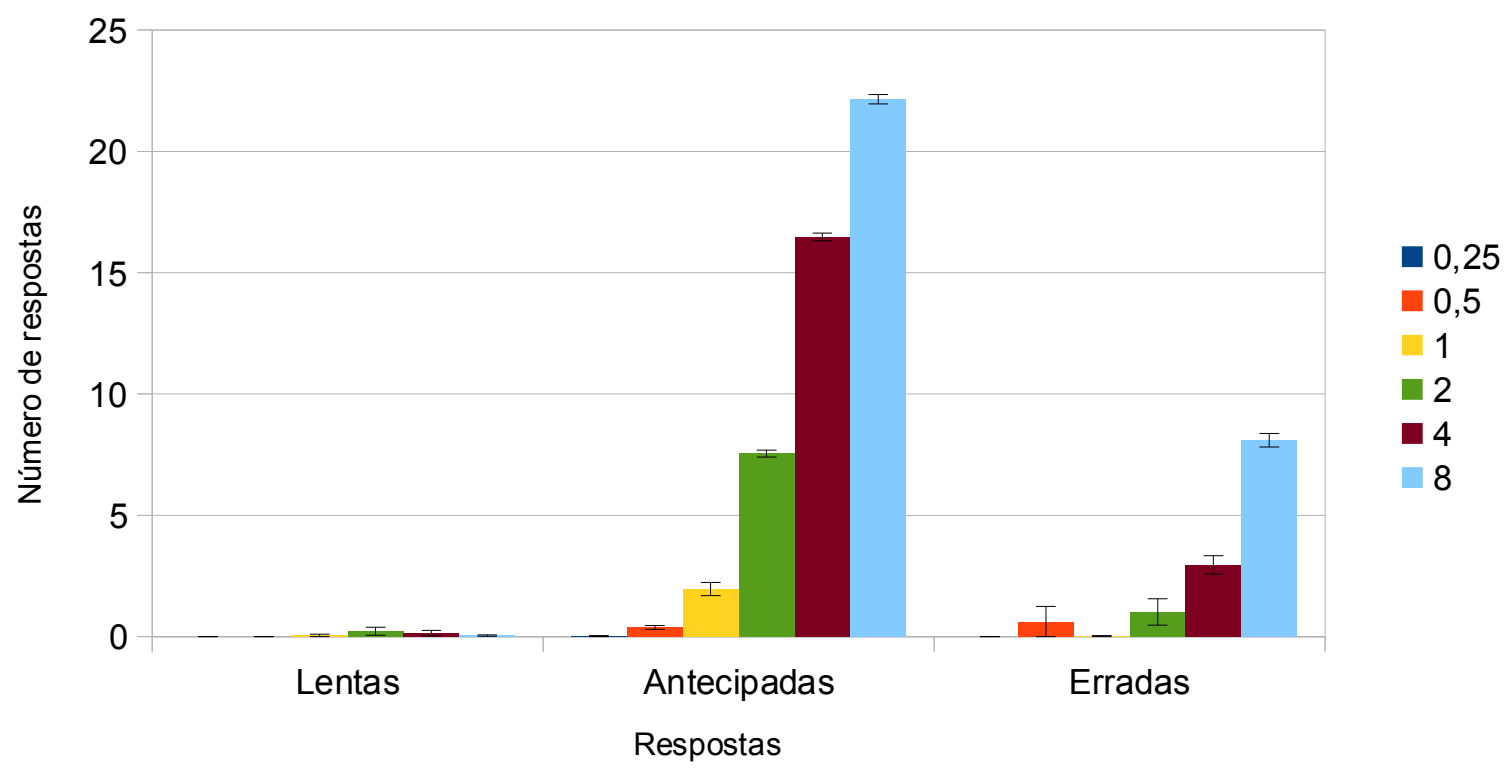

Figura 40 - Resultados obtidos no experimento 14: número de respostas lentas, antecipadas e erradas para os seis níveis de ruído analisados.

Este experimento deixa claro que o ruído aumenta os tempos de reação, bem como o número de respostas antecipadas e erradas.

As simulações em que o nível de ruído é 2 ou 4 foram as únicas até agora nesta série de experimentos em que o tempo de reação para a pista válida é o menor mesmo quando a pista válida é menos frequente do que a pista neutra. Estes resultados são os que mais se aproximam dos resultados obtidos com seres humanos. Eles indicam que os animais estão usando a informação fornecida pelas pistas válidas e sugerem que a existência de ruído e a necessidade de selecionar uma ação apropriada são ambos fatores necessários para que a informação dada por pistas válidas seja aproveitada.

Surpreendentemente, o tempo de reação para pistas válidas não é menor do que o tempo de reação para pistas neutras quando o nível de ruído é 8. Talvez o alto número de erros neste caso (mais da metade de todas as apresentações são antecipadas ou respondidas incorretamente) esteja sinalizando que é muito difícil detectar o alvo corretamente nestas simulações e a informação fornecida pela pista válida não ajude tanto quanto nos outros experimentos. Analogamente, se um problema é muito fácil, não precisamos de dicas para resolvê-lo. Se um problema já é mais difícil, ter dicas pode fazer muita diferença na nossa capacidade de resolvê-lo. Mas se um problema é extremamente difícil, mesmo tendo dicas não conseguimos resolvê-lo, de modo que 
tê-las ou não não fará diferença. Ainda assim, pelo fato de que o tempo de reação para pistas neutras não é menor do que o tempo de reação para pistas válidas, sabemos que os resultados obtidos não são devidos somente ao efeito da frequência.

\subsection{Experimentos 15 e 16}

Nestes experimentos, estudamos uma tarefa de tempo de reação de escolha com ruído, como foi feito no experimento anterior, mas analisamos o que acontece quando o ruído tem desvio padrão 2 e o número de pistas neutras é igual ao número de pistas válidas, assim como o que acontece quando o número de pistas neutras é igual ao número de pistas inválidas. Estes experimentos nos dão duas informações: qual é o benefício da pista válida sobre a pista neutra e o quão prejudicial é a informação incorreta dada pela pista inválida em relação à pista neutra, que não dá nenhuma informação. Esta análise somente será possível quando não houver mais o efeito da frequência, que por si só é capaz de modificar o tempo de reação.

\subsubsection{Métodos}

No experimento 15, o número de pistas válidas é igual ao número de pistas neutras. A proporção entre pistas válidas, neutras e inválidas é de 8:8:2. O número de apresentações na vida do animal é 36 e tanto as pistas válidas quanto as neutras estão presentes em $44 \%$ das apresentações.

No experimento 16, o número de pistas neutras é igual ao número de pistas inválidas. A proporção entre pistas válidas, neutras e inválidas é de 8:2:2. O número de apresentações na vida do animal é 24 e tanto as pistas inválidas quanto as neutras estão presentes em $17 \%$ das apresentações.

Para cada experimento, a simulação foi repetida 40 vezes. 


\subsubsection{Resultados e Discussão Parcial}

Os resultados estão mostrados na Figura 41 e na Figura 42. No experimento 15, os tempos de reação para pistas válidas, neutras e inválidas foram $37,18 \pm 0,84$, $42,48 \pm 0,97$ e $62,50 \pm 2,55$. No experimento 16 , os tempos de reação para pistas válidas, neutras e inválidas foram 37,94 \pm 0,58, 49,64 \pm 1,83 e 60,23 $\pm 2,19$ (média \pm erro padrão da média).

O experimento 15 mostra que a pista válida tem um efeito benéfico de $-5,30$ unidades de tempo ou de $-12,5 \%$ em relação à pista neutra, independentemente do efeito da frequência, que não existe neste experimento. Já a pista inválida, pelo experimento
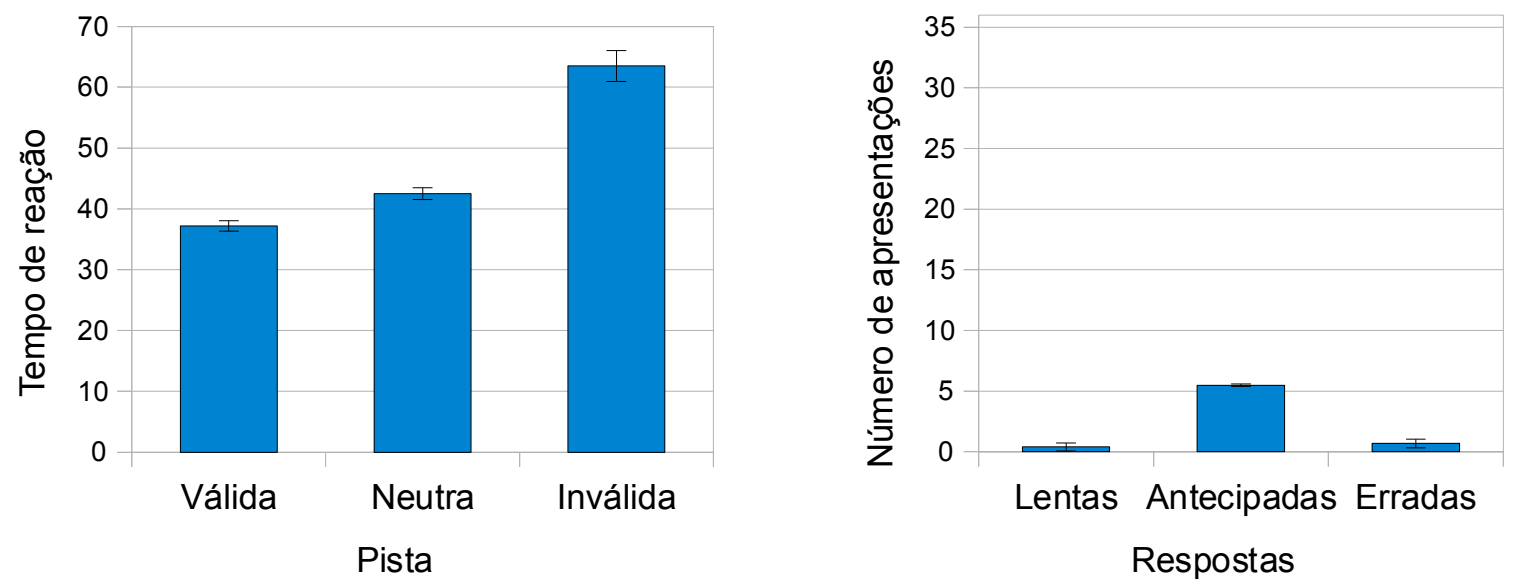

Figura 41 - Resultado do experimento 15, em que o número de pistas válidas é igual ao número de pistas neutras.
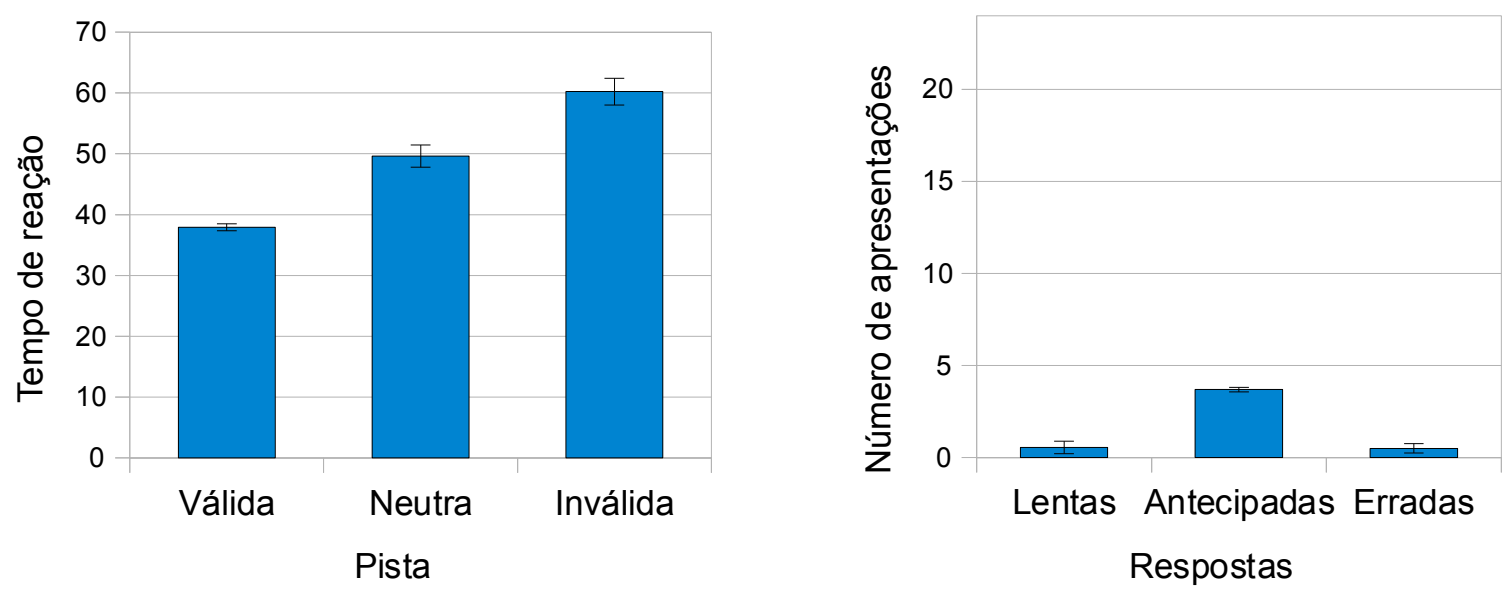

Figura 42 - Resultado do experimento 16, em que o número de pistas neutras é igual ao número de pistas inválidas. 
16, tem um efeito prejudicial de 10,59 unidades de tempo ou de $21,3 \%$ em relação à pista neutra, também independentemente do efeito da frequência.

Os resultados mostram o tamanho do benefício conferido pela informação contida na pista válida (o local em que o alvo vai aparecer) e mostram que a informação incorreta fornecida pela pista inválida de fato causa um aumento no tempo de reação em relação à ausência de informação fornecida pela pista neutra.

\subsection{Experimento 17}

No modelo dos experimentos anteriores, com ruído, o tempo de reação menor observado para a pista válida do que para a neutra é uma consequência do ruído e da necessidade de se gerar uma resposta correta ao alvo. Não é claro como o outro fator que discutimos na seção 6, a quantidade de recursos computacionais da rede neural, possa modular este resultado. Com um número maior de neurônios, aumentaria o ruído interno da rede neural; por outro lado, aumentaria o poder de processamento da rede. No entanto, também não é claro por que um maior poder de processamento seria vantajoso nesta tarefa. Como já havíamos comentado, o melhor desempenho foi obtido pela rede mais simples, quando não há ruído. Assim, neste experimento, aumentamos o número de nós internos da rede neural.

\subsubsection{Métodos}

A rede neural ganhou 7 nós internos, sendo que cada nó da rede neural continuou conectado a todos os outros nós. O ruído tinha desvio padrão 2 e era aplicado a cada nó da rede neural. A proporção entre pistas válidas, neutras e inválidas era 8:15:2. Esta simulação foi repetida 25 vezes. 


\subsubsection{Resultados e Discussão Parcial}

Os resultados são mostrados na Figura 43. Comparamos os tempos de reação deste experimento com os do experimento 14, ruído 2, usando múltipos testes-t e respectiva correção de Bonferroni. O tempo de reação para a pista válida neste experimento é menor do que no experimento $14(34,75 \pm 0,82$ é diferente de 37,72 $\pm 0,67$; $\mathrm{p}=0,02)$, mas não para os outros tipos de pista.
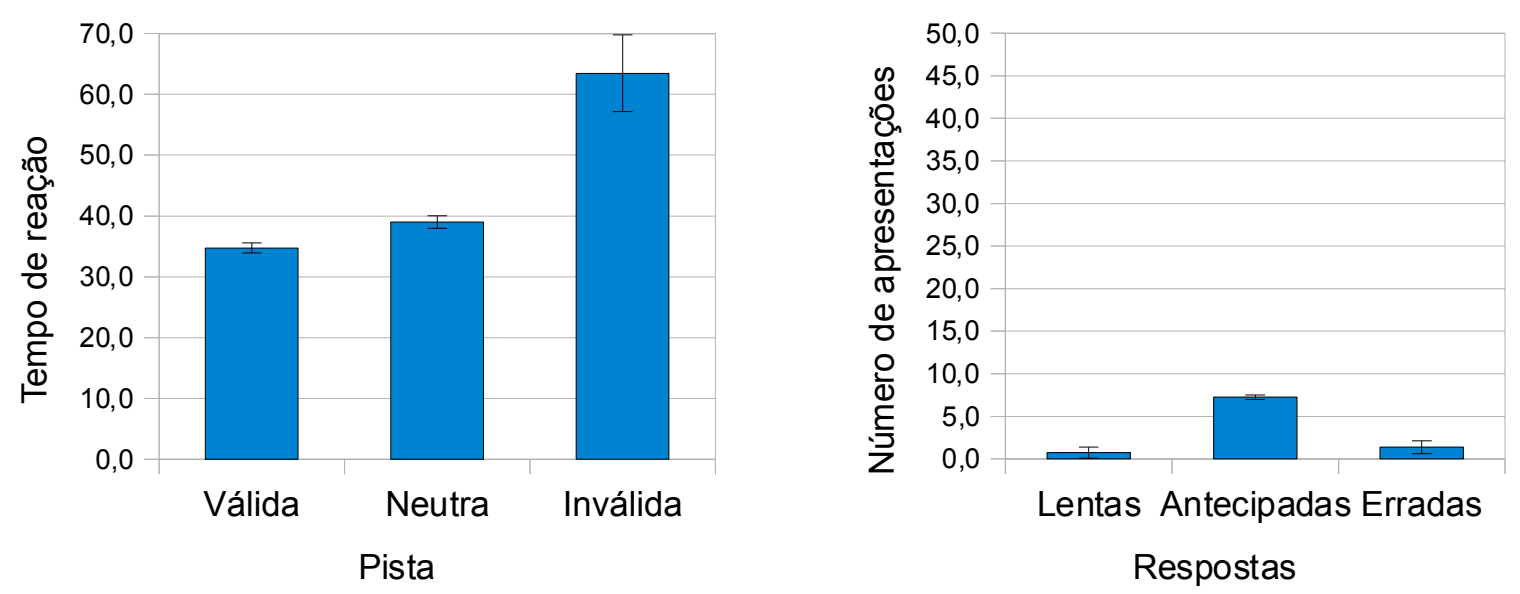

Figura 43 - Resultados do experimento 17.

Recursos computacionais adicionados às redes neurais não anularam o efeito atencional na tarefa; ao contrário, eles podem ter aumentado a vantagem dada pela pista válida, o que corresponde a um maior efeito atencional. Estes resultados não são surpreendentes visto que uma maior quantidade de neurônios não é necessária para a realização da tarefa e na verdade aumenta o nível de ruído interno da rede neural.

\subsection{Discussão parcial da seção 6}

Nestes experimentos envolvendo tempo de reação, populações de animais artificiais evoluíram pela aplicação de um algoritmo genético, sendo o valor adaptativo de cada indivíduo calculado em função do seu desempenho em uma tarefa de tempo de reação. $\mathrm{O}$ valor adaptativo era maior quanto mais rapidamente o indivíduo respondia após aparecimento do alvo, contanto que a resposta estivesse correta, nos experimentos de tempo de reação de escolha. Eles mostram em geral que redes neurais artificiais evoluindo em um ambiente de vida artificial podem ser modelos úteis na 
investigação dos princípios fisiológicos inerentes a medidas de tempos de reação em tarefas de resposta simples ou de escolha.

O primeiro experimento (experimento 9, na página 87) simplesmente segue os métodos empregados no experimento de Posner (1980), sem ruído nem seleção de ação. Os resultados obtidos mostram que os animais tiveram um desempenho perfeito, ou seja, respondiam ao aparecimento do alvo no menor tempo possível, sem erros. A estrutura deste experimento lembra, por sua simplicidade tanto na rede neural quanto na tarefa, o circuito lâmpada-interruptor mencionado na introdução. Seria, pois, muito simples construir uma máquina que realiza rapidamente e sem erros a tarefa considerada; no entanto, esta máquina, ao contrário do ser humano, só saberia lidar com esta situação específica, em que os sinais são inequívocos e só existe uma resposta possível.

Como pela própria natureza da tarefa os números de pistas válidas, neutras e inválidas eram diferentes, tornou-se logo claro que somente as diferenças nas frequências das pistas já poderiam gerar uma diferença nos tempos de reação (efeito da frequência), pois quanto mais frequente era um tipo de apresentação na vida de um indivíduo, mais este tipo contribuía para o valor adaptativo daquele indivíduo. Por isso, na maioria dos experimentos, usamos o número de pistas neutras maior ou igual ao número de pistas válidas. Deste modo, se observássemos uma diminuição do tempo de reação para as pistas válidas em relação às neutras, saberíamos que ele não seria devido ao efeito da frequência.

É provável que, devido ao aprendizado, o efeito da frequência se aplique também em experimentos com seres humanos. Parte da diferença entre os tempos de reação observados para a pista válida, neutra e inválida, que em geral é totalmente atribuída à ação da atenção voluntária e a fenômenos sensoriais, deve ser gerado pelo efeito da frequência - geralmente, há menos pistas inválidas do que neutras e menos neutras do que válidas. Por outro lado, pode-se considerar o efeito da frequência um fenômeno atencional também, em que os estímulos mais frequentes capturam mais a atenção devido à sua maior relevância. De qualquer modo, ele não se deve à informação fornecida pelas pistas.

Voltando aos nossos experimentos acima, a adição de ruído teve um enorme efeito no aumento dos tempos de reação, bem como do número de erros. Ela parece ser um elemento essencial para que os tempos de reação não convirjam para a unida- 
de temporal mínima (passo da simulação), e possam se distribuir por um intervalo amplo o suficiente para refletir a eventual modulação por fatores de interesse.

Em todos os experimentos com tarefas de resposta simples, os tempos de reação escalam com a frequência das pistas, e não com as suas validades. Com a introdução da seleção de ação no nosso modelo em adição ao ruído, saímos do cenário simples do experimento 9. A adição de seleção de ação, por si só, não alterou os resultados obtidos, mas com combinada ao ruído, observamos o tempo de reação para pistas válidas menor do que o tempo de reação para pistas neutras, ainda que o efeito da frequência favorecesse as pistas neutras na maioria dos experimentos. Em seres humanos, talvez estes fatores também sejam responsáveis por gerar, evolutivamente, grande parte do efeito atencional observado. Assim como nos experimentos da seção 5, "Alocação da atenção espacial", aqui também a atenção se relaciona ao fato de que alguns estímulos (alvo e pista) são mais importantes do que outros (ruído). Neste caso, é necessário que os circuitos de tomada de decisão sejam influenciados somente por estímulos relevantes a fim de que a ação correta seja tomada (seleção para a ação).

No último experimento, aumentamos o tamanho da rede neural a fim de testar uma possível diminuição do efeito atencional com o aumento de recursos computacionais, mas esta diminuição não aconteceu. Ao contrário, houve um possível aumento na vantagem conferida pela pista válida, o que aumentou o efeito atencional. Isso pode ter acontecido porque a rede neural já possui todos os recursos computacionais necessários para executar esta tarefa com máxima eficiência, bem como porque neurônios extras adicionam também ruído interno extra. De qualquer modo, nesta série de experimentos com tempo de reação, assim como na seção 5, o conceito de recursos limitados não foi útil para entender o surgimento da atenção.

Em resumo, o modelo mais simples, que já captura minimamente os aspectos inerentes à modulação atencional dos tempos de resposta, é uma rede neural com neurônios do tipo integra-e-dispara, simulando uma tarefa de tempo de reação de escolha, na qual seja adicionada uma dose adequada de ruído (não alta o suficiente para corromper o processamento e nem tão baixa que permita a rede convergir para uma faixa estreita e mínima de tempos de resposta). 


\section{DISCUSSÃO GERAL}

Sabemos pela literatura e pelos resultados do experimento 1 que em geral o ser humano, ao contrário de outros animais, não adota a estratégia ótima em experimentos de escolha binária repetida cuja sequência de resultados é dada por uma cadeia de Markov de ordem 0 . Os nossos resultados mostraram que existia uma flexibilidade na estratégia adotada pelos sujeitos: o desempenho deles melhorava ao longo do experimento e ao receber a informação de como a sequência de apresentações era gerada. No entanto, muito poucos sujeitos atingiram o desempenho ótimo.

A partir de nossos resultados no experimento 2, pudemos propor que existem vantagens evolutivas em se buscar um possível padrão intrínseco que determina a ocorrência de fenômenos repetitivos. Essa estratégia é útil quando (1) existe, de fato, um padrão subjacente e (2) o animal possui condições de decifrá-lo (capacidade cognitiva compatível com a complexidade do fenômeno e tempo suficiente). Nesse caso, o animal terá grande vantagem adaptativa em um cenário suficientemente regular e decifrável. No entanto, ele adotará uma estratégia sub-ótima (pareamento de frequências) quando confrontado com fenômenos aleatórios de memória nula. Já animais com pequena capacidade cognitiva relativa são favorecidos pela adoção de uma estratégia perseverante, já que esta é uma solução maximizadora na maioria dos cenários (neste caso, dada a capacidade cognitiva reduzida do animal, não há diferença pragmática entre um cenário regular e outro aleatório).

Portanto, não só pudemos demonstrar de forma simples que a estratégia de pareamento de probabilidades de fato pode surgir de uma busca por padrões de regularidade, mas também podemos concluir que provavelmente se constitui em uma estratégia ótima na maioria dos cenários ecologicamente válidos para o ser humano, dada a sua capacidade cognitiva e tempo disponível. A estratégia de busca por padrões conduz a um resultado sub-ótimo em condições não ecológicas de laboratório ou condições naturais eventuais de possível baixo impacto adaptativo, onde os fenômenos repetitivos carecem de qualquer memória e regularidade intrínseca. Nesse caso, o prejuízo imputado pela estratégia de busca de padrões é, como evidenciado matematicamente na Figura 12, mais que compensado pelos ganhos oriundos da mesma estratégia em condições onde os fenômenos repetitivos são regidos por um padrão subjacente. 
Nos experimentos sobre atenção, ao tentarmos reproduzir em redes neurais algumas características deste fenômeno, algumas ideias se mostraram mais úteis do que outras. Uma ideia amplamente mencionada na literatura sobre atenção é a de o sistema nervoso possui capacidade limitada para processar estímulos sensoriais e o papel da atenção é o de selecionar somente os estímulos mais importantes de forma a não sobrecarregar o sistema. Em nossos experimentos, a introdução desta ideia nas simulações não produziu os resultados esperados, nem nos experimentos de alocação da atenção espacial, nem nos experimentos de tempo de reação. Ao invés disso, nossos experimentos reforçam ideias diferentes: as de que o sistema nervoso se focaliza no que é relevante para a ação, pois só existe pressão seletiva para processar este tipo de informação, e o sistema nervoso deve inibir estímulos distratores a fim de que eles não influenciem os circuitos de tomada de decisão e a ação apropriada seja selecionada somente com base em estímulos relevantes. A primeira ideia não é em geral mencionada na literatura, mas a segunda aborda um problema amplamente reconhecido, como discutido na introdução da seção sobre tempo de reação. Concluímos que embora o sistema nervoso humano seja de fato limitado e esta limitação possa ter um papel fundamental para explicar os resultados de certos tipos de experimento, os aspectos que abordamos aqui não resultam desta limitação. Mesulam (MESULAM, 1985) afirmou que "se o cérebro tivesse capacidade infinita para processar informações, haveria pouca necessidade para mecanismos atencionais", mas nossos experimentos indicam que isso não é verdade; ao contrário, a necessidade de inibir estímulos irrelevantes pode gerar em parte esta limitação. Além disso, como já observamos, módulos de processamento sensorial só podem evoluir concomitantemente com a capacidade de transformar esta informação sensorial em ação adaptativa. Assim, muitas possíveis limitações sensoriais não são relevantes, pois mesmo se elas não existissem, ainda assim não teríamos a capacidade de usar as informações obtidas para a ação.

Outro "gargalo" atencional é dado pela natureza unitária do processo consciente - para o qual a atenção é considerada uma condição necessária - e pelo fato imperioso e inexorável de que uma única ação deverá ser selecionada e executada em uma janela temporal viável e com resultados ecologicamente vantajosos. Este é um fato que os nossos experimentos de simulação evolutiva em particular ressaltam, pois somente as ações de um animal têm um impacto direto no seu valor adaptativo. Assim, 
a atenção, como aliás todos os outros componentes da percepção, está subordinada à ação.

Não podemos voltar ao passado e observar a evolução biológica do nosso sistema nervoso, por isso devemos inferir o que aconteceu a partir de experimentos com seres humanos e animais modernos, modelos matemáticos, como os discutidos neste trabalho, e outros métodos. Os resultados discutidos aqui nos ajudam a entender a atenção e a tomada de decisão como processos influenciados pelos problemas que nossos antepassados enfrentaram, resultantes de certos aspectos do ambiente que buscamos determinar. Assim, podemos ver como a evolução moldou a nossa cognição e entender que o nosso pensamento, por mais abstrato que às vezes pareça, também surgiu da necessidade de sobreviver e se reproduzir no mundo e está estritamente ligado a ela. 


\section{CONCLUSÕES}

1. O processo evolutivo deixa vieses no sistema nervoso de forma a optimizar as nossas capacidades cognitivas para a sobrevivência e reprodução no ambiente em que evoluímos.

2. Em outros ambientes, estas capacidades podem ser sub-ótimas. Por exemplo, no experimento de escolha binária repetida, os seres humanos em geral adotam pareamento de probabilidades. Nossos experimentos sugerem que este comportamento parece ser o resultado de um comportamento, consciente ou não, voltado à busca de padrões simples que determinem a sucessão de eventos periódicos, ainda que aparentemente complexos.

3. A eficiência de uma estratégia de busca por padrões em produzir resultados ótimos ou sub-ótimos depende da relação entre a capacidade cognitiva do organismo e a complexidade da sequência de eventos com a qual tem que lidar: em condições em que o potencial cognitivo é predominantemente inferior quando comparado à complexidade do meio, a estratégia ótima se constitui em perseverar na escolha da recompensa de maior frequência, o que leva à maximização. Já quando o potencial cognitivo é suficiente para enfrentar uma parcela relevante das complexidades do ambientes, a busca por padrões terá uma dentre duas possíveis consequências: (1) levará a resultados que tenderão aos ótimos no caso de um padrão de regularidade ser encontrado (este é o caso em que o "código foi quebrado"); (2) no caso da estratégia de busca por padrões não ser bem-sucedida - o que acontece em condições de completa imprevisibilidade (por exemplo, uma sequência de Bernoulli), serão obtidos resultados sub-ótimos (em comparação à estratégia de perseveração).

4. A capacidade limitada do sistema nervoso não parece ser a única explicação plausível para a necessidade de mecanismos atencionais. A alocação da atenção existe mesmo em condições de capacidade excedente de processamento, $\mathrm{o}$ que refuta a ideia segundo a qual, caso o sistema nervoso possuísse uma capacidade ilimitada de processamento, seria desnecessário qualquer tipo de alocação da atenção.

5. É possível que a alocação da atenção - com suas características marcantes de processamento serial e lento - esteja fundamentalmente condicionada aos pro- 
cessos de seleção e execução da ação a ser emitida, e não aos processos de seleção e processamento dos estímulos sensoriais relevantes.

6. Modelos relativamente simples de redes neurais artificiais podem constituir valiosas ferramentas na simulação de tarefas de detecção e de tempo de reação, permitindo averiguar a influência, sobre o resultado comportamental simulado, de fatores tais como a natureza da tarefa, a validade de pistas atencionais, a arquitetura e capacidade de processamento da rede, a presença de diferentes níveis de ruído interno ou externo, entre outros. 


\section{REFERÊNCIAS ${ }^{2}$}

ACUÑA, D. E.; SCHRATER, P. Structure Learning in Human Sequential DecisionMaking. PLoS Computational Biology, v. 6, n. 12, p. e1001003, 2010.

ALLPORT, A. Selection for action: Some behavioral and neurophysiological considerations of attention and action. In: HEUER, H.; SANDERS, A. F. (Ed.). Perspectives on perception and action. Hillsdale, NJ: Lawrence Erlbaum Associates, 1987. p. 395419.

BALDO, M. V. C.; KIHARA, A. H.; NAMBA, J.; KLEIN, S. A. Evidence for an attentional component of the perceptual misalignment between moving and flashing stimuli. Perception, v. 31, n. 1, p. 17-30, 2002.

BALDO, M. V. C.; KLEIN, S. A. Extrapolation or attention shift? Nature, v. 378, n. 6557, p. 565-566, 1995.

BARHILLEL, M.; WAGENAAR, W. The perception of randomness. Advances in Applied Mathematics, v. 12, n. 4, p. 428-454, 1991.

BARTOLOMEO, P.; PAGLIARINI, L.; PARISI, D. Emergence of Orienting Behavior in Ecological Neural Networks. Neural Process. Lett., v. 15, n. 1, p. 69-76, 2002.

BEHREND, E. R.; BITTERMAN, M. E. Probability-matching in the fish. The American Journal of Psychology, v. 74, n. 4, p. 542-551, 1961.

BLISS, J. P.; GILSON, R. D.; DEATON, J. E. Human probability matching behaviour in response to alarms of varying reliability. Ergonomics, v. 38, n. 11, p. 2300-2312, 1995.

BROADBENT, D. E. Perception and Communication. London: Pergamon Press, 1958.

CELA-CONDE, C. J.; AYALA, F. J. Human Evolution. New York: Oxford University Press, 2007.

${ }^{2}$ De acordo com:

ASSOCIAÇÃO BRASILEIRA DE NORMAS TÉCNICAS. NBR 6023: Informação e documentação: referências: elaboração. Rio de Janeiro, 2002. 
CRAVO, A. M.; BALDO, M. V. C. A psychophysical and computational analysis of the spatio-temporal mechanisms underlying the flash-lag effect. Perception, v. 37, n. 12, p. 1850-1866, 2008.

DAYAN, P.; KAKADE, S.; MONTAGUE, P. R. Learning and selective attention. Nature Neuroscience, v. 3, p. 1218-1223, 2000.

DESIMONE, R.; DUNCAN, J. Neural mechanisms of selective visual attention. Annual Review of Neuroscience, v. 18, p. 193-222, 1995.

DOSHER, B. A.; LU, Z.-L. Noise exclusion in spatial attention. Psychological Science, v. 11, n. 2, p. 139-146, 2000.

ERIKSEN, C. W.; HOFFMAN, J. E. The extent of processing of noise elements during selective encoding from visual displays. Perception \& Psychophysics, v. 14, n. 1, p. 155-160, 1973.

FALK, R.; KONOLD, C. Making sense of randomness: Implicit encoding as a basis for judgment. Psychological Review, v. 104, n. 2, p. 301-318, 1997.

FANTINO, E.; ESFANDIARI, A. Probability matching: encouraging optimal responding in humans. Canadian Journal of Experimental Psychology $=$ Revue Canadienne de Psychologie Expérimentale, v. 56, n. 1, p. 58-63, 2002.

FEHER-DA-SILVA, C. Surgimento de Atenção Seletiva em Redes Neurais Artificiais 3Evoluindo em Ambientes com Estímulos Complexos. 2005. 112 f. Dissertação (Mestrado em Fisiologia Humana) - Instituto de Ciências Biomédicas, Universidade de São Paulo, São Paulo, 2005.

FEHER-DA-SILVA, C.; CATICHA, N.; BALDO, M. V. C. Emergence of sensory selection mechanisms in Artificial Life simulations. BMC Neuroscience, v. 9, p. P78, 2008. Suppl 1.

FLOREANO, D.; URZELAI, J. Evolutionary Robotics: The Next Generation. In: GOMI, T. (Ed.). Evolutionary Robotics III. Ontario (Canada): AAI Books. 2000.

FLOREANO, D.; URZELAI, J. Evolution of Plastic Control Networks. Auton. Robots, v. 11, n. 3, p. 311-317, 2001. 
GAISSMAIER, W.; SCHOOLER, L. J. The smart potential behind probability matching. Cognition, v. 109, n. 3, p. 416-422, 2008.

GAZZANIGA, M. S.; IVRY, R. B.; MANGUN, G. R. Cognitive Neuroscience. New York: W. W. Norton \& Company, 1998.

GRAF, V.; BULLOCK, D. H.; BITTERMAN, M. E. Further experiments on probabilitymatching in the pigeon. Journal of the Experimental Analysis of Behavior, v. 7, n. 2, p. 151, 1964.

GRANT, B. S. Fine tuning the peppered moth paradigm. Evolution, v. 53, n. 3, p. $980-$ 984, 1999.

HARDY-VALLÉE, B. Artificial life, natural rationality and probability matching. In: IEEE SYMPOSIUM ON ARTIFICIAL LIFE, 2007, Honolulu, HI. Anais... IEEE, 2007. p. 123-129.

HASELTON, M. G.; BRYANT, G. A; WILKE, A.; et al. Adaptive Rationality: An Evolutionary Perspective on Cognitive Bias. Social Cognition, Oct. 2009.

HAYKIN, S. Neural Networks: A Comprehensive Foundation. 2nd ed. Upper Saddle River, NJ, USA: Prentice Hall, 1998.

HEALY, A. F.; KUBOVY, M. Probability matching and the formation of conservative decision rules in a numerical analog of signal detection. Journal of Experimental Psychology: Human Learning \& Memory, v. 7, n. 5, p. 344-354, 1981.

HEBB, D. O. The organization of behavior: A neuropsychological theory. New York: John Wiley and Sons, Inc., 1949.

HERCULANO-HOUZEL, S. Scaling of Brain Metabolism with a Fixed Energy Budget per Neuron: Implications for Neuronal Activity, Plasticity and Evolution. (M. PERC, Ed.)PLoS ONE, v. 6, n. 3, p. e17514, 2011.

HERRNSTEIN, R. J. Relative and absolute strength of response as a function of frequency of reinforcement. Journal of the Experimental Analysis of Behavior, v. 4, n. 3, p. 267-272, 1961.

HINDMOOR, A. Rational Choice. New York: Palgrave Macmillan, 2006. 
HINTON, G. E.; NOWLAN, S. J. How learning guides evolution. Complex Systems, v. 1, p. 495-502, 1987.

HOKKANEN, J. E. Visual simulations, artificial animals and virtual ecosystems. The Journal of Experimental Biology, v. 202, pt. 23, p. 3477-3484, 1999.

KOEHLER, D. J.; JAMES, G. Probability matching in choice under uncertainty: intuition versus deliberation. Cognition, v. 113, n. 1, p. 123-127, 2009.

LU, Z.-L.; LESMES, L. A; DOSHER, B. A. Spatial attention excludes external noise at the target location. Journal of vision, v. 2, n. 4, p. 312-323, 2002.

MACMILLAN, N. A.; CREELMAN, C. D. Detection Theory. 2nd ed. New York: Psychology Press, 2004.

MESULAM, M.-M. Attention, confusional states, and neglect. In: . Principles of Behavioral Neurology. Oxford, UK: Oxford University Press. 1985. p. 125-168.

MILLER, M. B.; VALSANGKAR-SMYTH, M. Probability matching in the right hemisphere. Brain and Cognition, v. 57, n. 2, p. 165-167, 2005.

MITCHELL, M. An Introduction to Genetic Algorithms (Complex Adaptive Systems). Cambridge, Mass.: The MIT Press, 1998.

MORRIS, G.; NEVET, A.; ARKADIR, D.; VAADIA, E.; BERGMAN, H. Midbrain dopamine neurons encode decisions for future action. Nature Neuroscience, v. 9, n. 8, p. 1057-1063, 2006.

NAMBA, J.; BALDO, M. V. C. The modulation of the flash-lag effect by voluntary attention. Perception, v. 33, n. 5, p. 621-631, 2004.

NIV, Y.; JOEL, D.; MEILIJSON, I.; RUPPIN, E. Evolution of Reinforcement Learning in Uncertain Environments: A Simple Explanation for Complex Foraging Behaviors. Adaptive Behavior, v. 10, n. 1, p. 5-24, 2002.

NOLFI, S. Evolution and learning in neural networks. In: ARBIB, M. A. (Ed.). Handbook of brain theory and neural networks. Cambridge, MA: MIT Press, 2002. p. 415418. 
NOLFI, S.; FLOREANO, D. Learning and Evolution. Autonomous Robots, v. 7, n. 1, p. 89-113, 1999.

NOLFI, S.; PARISI, D. Evolution of Artificial Neural Networks. In: ARBIB, M. A. (Ed.). Handbook of brain theory and neural networks. Cambridge, MA: MIT Press, 2002. p. 418-421.

NOLFI, S.; PARISI, D.; ELMAN, J. L. Learning and Evolution in Neural Networks. Adaptive Behavior, v. 3, n. 1, p. 5-28, 1994.

PARDUCCI, A.; POLT, J. Correction vs. noncorrection with changing reinforcement schedules. Journal of Comparative and Physiological Psychology, v. 51, n. 4, p. 492495, 1958.

PARISI, D. Artificial life and higher level cognition. Brain and Cognition, v. 34, n. 1, p. 160-84, 1997.

PARISI, D. Can neural networks help us explain the phenomena of consciousness? In: CARLO ERBA CONFERENCE ON THE MIND F. C. ERBA, 2000, Milan. Anais... Milano: Carlo Erba, 2001. p. 17-37.

POSNER, M. I. Orienting of attention. The Quarterly Journal of Experimental Psychology, v. 32, n. 1, p. 3-25, 1980.

REYNOLDS, J. H.; HEEGER, D. J. The normalization model of attention. Neuron, v. 61, n. 2, p. 168-185, 2009.

SABES, P. N.; JORDAN, M. I. Reinforcement learning by probability matching. Advances in Neural Information Processing Systems, v. 8, p. 1080-1086, 1996.

SETH, A. K. Modeling Group Foraging: Individual Suboptimality, Interference, and a Kind of Matching. Adaptive Behavior, v. 9, n. 2, p. 67-89, 2001.

SETH, A. K. The ecology of action selection: insights from artificial life. Philosophical transactions of the Royal Society of London. Series B, Biological sciences, v. 362, n. 1485, p. 1545-1558, 2007. 
SHANKS, D. R.; TUNNEY, R. J.; MCCARTHY, J. D. A re-examination of probability matching and rational choice. Journal of Behavioral Decision Making, v. 15, n. 3, p. 233-250, 2002.

SHIU, L.-PO; PASHLER, H. Negligible effect of spatial precuing on identification of single digits. Journal of Experimental Psychology: Human Perception and Performance, v. 20, n. 5, p. 1037-1054, 1994.

STEELS, L. The Artificial Life Roots of Artificial Intelligence. Artificial Life, v. 1, n. 12, p. 75-110, 1993.

TRAPPENBERG, T. Fundamentals of Computational Neuroscience. Oxford: Oxford University Press, 2002.

UNTURBE, J.; COROMINAS, J. Probability matching involves rule-generating ability: a neuropsychological mechanism dealing with probabilities. Neuropsychology, v. 21, n. 5, p. 621-630, 2007.

VULKAN, N. An Economist's Perspective on Probability Matching. Journal of Economic Surveys, v. 14, n. 1, p. 101-118, 2000.

WATTS, J. M. Animats: computer-simulated animals in behavioral research. J. Anim Sci., v. 76, n. 10, p. 2596-2604, 1998.

WHITLEY, L. D. Fundamental principles of deception in genetic search. In: RAW LINS, G. J. E. (Ed.). Foundations of Genetic Algorithms. San Mateo, CA: Morgan Kaufmann. p. 221-241.

WHITLEY, L. D. A Genetic Algorithm Tutorial. Statistics and Computing, v. 4, p. 6585, 1994.

WOLFORD, G.; MILLER, M. B.; GAZZANIGA, M. S. The Left Hemisphere's Role in Hypothesis Formation. The Journal of Neuroscience, v. 20, n. RC64, p. 1-4, 2000.

WOZNY, D. R.; BEIERHOLM, U. R.; SHAMS, L. Probability Matching as a Computational Strategy Used in Perception. PLoS Computational Biology, v. 6, n. 8, p. e1000871, 2010. 